BUKU AJAR

PSIKOLOGI SOSIAL

(UP) 


\section{BUKU AJAR \\ PSIKOLOGI SOSIAL \\ JILID I}

Disusun oleh:

Effy Wardati Maryam, S.Psi.,M.Si

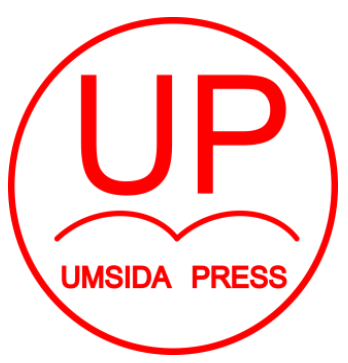

Diterbitkan oleh UMSIDA PRESS

Jl. Mojopahit 666 B Sidoarjo

ISBN: 978-602-5914-29-4

Copyright@2018.

Authors

All rights reserved 
BUKU AJAR

\section{PSIKOLOGI SOSIAL \\ JILID I}

Penulis :

Effy Wardati Maryam, S.Psi.,M.Si

\section{ISBN :}

978-602-5914-29-4

\section{Editor :}

Septi Budi Sartika, M.Pd

M. Tanzil Multazam, S.H., M.Kn.

\section{Copy Editor :}

Fika Megawati, S.Pd., M.Pd.

\section{Design Sampul dan Tata Letak :}

Mochamad Nashrullah, S.Pd

\section{Penerbit :}

UMSIDA Press

\section{Redaksi :}

Universitas Muhammadiyah Sidoarjo

Jl. Mojopahit No 666B

Sidoarjo, Jawa TImur

\section{Cetakan pertama, Agustus 2018}

(C) Hak cipta dilindungi undang-undang

Dilarang memperbanyak karya tulis ini dengan suatu apapun tanpa ijin tertulis dari penerbit. 


\section{IDENTITAS BUKU}

Judul Buku

: Psikologi Sosial, Jilid 1

Penulis

: Effy Wardati Maryam

Penerbit

: UMSIDA Press, Sidoarjo

Cetakan

: Pertama, Sidoarjo

Tahun

: 2018

Jumlah Halaman : 150 halaman

Jenis Kertas $\quad: \quad$ A5

Ukuran

: $14,8 \times 21,0 \mathrm{~cm}$

ISBN

Deskripsi Singkat : Buku ini merupakan buku ajar untuk mata kuliah Psikologi Sosial, yang merupakan mata kuliah wajib di Prodi Psikologi. Buku ini dapat dimanfaatkan oleh dosen maupun mahasiswa yang mendalami bidang Psikologi Sosial, juga oleh peminat lain yang berasal dari disiplin ilmu di luar psikologi. Bahasa yang digunakan dalam buku ini disusun secara sederhana dan lugas sehingga mudah dibaca oleh siapapun yang membacanya. Secara berturut-turut buku ini membahas tentang pendahuluan (sejarah perkembangan psikologi sosial, pengertian 
psikologi sosial, ruang lingkup, dan kedudukan psikologi sosial), teori-teori dasar psikologi sosial, metode penelitian, diri sosial, persepsi sosial, kognisi sosial, sikap, serta daya tarik interpersonal dan hubungan erat. 


\section{KATA PENGANTAR}

Alhamdulillah, puji syukur penulis panjatkan ke hadirat Allah S.W.T., karena atas limpahan rahmat-Nya maka buku ini bisa diselesaikan.

Buku ini merupakan edisi pertama, dimana di dalamnya mencakup beberapa topik utama yang menjadi kajian Psikologi Sosial, disertai dengan contoh-contoh berdasarkan hasil penelitian maupun fenomena-fenomena sosial di masyarakat. Sebagai pedoman mengajar, buku ini dilengkapi dengan capaian pembelajaran mata kuliah. Buku ini dibuat sebagai bahan ajar bagi mahasiswa untuk mempermudah pelaksanaan belajar mengajar pada mata kuliah Psikologi Sosial. Harapan penulis dengan diterbitkannya buku ini, bisa menambah wawasan mahasiswa di bidang psikologi sosial secara lebih mendalam.

Penulis menyadari sepenuhnya bahwa buku ini masih jauh dari kesempurnaan, meskipun kami telah berusaha sebaik-baiknya. Oleh karena itu, penulis mengharapkan masukan dan saran untuk penyempurnaan buku ini di masa yang akan datang.

Akhirnya penulis mengucapkan terima kasih kepada semua pihak atas dukungan yang telah diberikan, khususnya kepada UMSIDA Press yang telah memberikan kesempatan hingga tulisan ini dapat diterbitkan. Semoga buku ini dapat memberikan manfaat bagi siapa saja yang membutuhkan.

Sidoarjo, 31 Juli 2018

Penulis 


\section{DAFTAR ISI}

JUDUL

IDENTITAS BUKU

KATA PENGANTAR

DAFTAR ISI

BAB 1 : PENDAHULUAN

A. Sejarah Perkembangan Psikologi Sosial

B. Pengertian Psikologi Sosial

C. Faktor-faktor Penyebab Pemikiran dan

Perilaku Sosial

D. Ruang Lingkup Psikologi Sosial

E. Kedudukan Psikologi Sosial Dengan Ilmuilmu Sosial Lain

BAB 2 : TEORI-TEORI DASAR PSIKOLOGI SOSIAL

A. Perspektif Sosiokultural

(The Sociocultural Perspective)

B. Perspektif Evolusioner

(The Evolutionary Perspective)

C. Perspektif Belajar Sosial

(The Social Learning Perspective)

D. Perspektif Fenomenologi

(The Phenomenological Perspective)

E. Perspektif Kognitif Sosial

(The Social Cognitive Perspective)

F. Perspektif Interaksionis Simbolik

(The Symbolic Interactionist Frame) 

G. Teori Pernyataan Harapan (Expectations States Theory)
H. Teori Pertukaran Sosial (Social Exchange Theory)
A. Membangun Ide Penelitian (Memulai Proses Penelitian)
B. Menyempurnakan Ide Penelitian
(Mendefinisikan dan Mengukur Variabel Psikologi Sosial)
C. Menguji Ide Penelitian (Desain Penelitian Psikologi Sosial)
D. Etika Penelitian Psikologi Sosial

BAB 4 : DIRI SOSIAL (SOCIAL-SELF)
A. Konsep Diri (self-concept)
B. Harga Diri (self-esteem)
C. Kesadaran Diri (self-awareness)
D. Presentasi Diri (self-presentation)
E. Pengungkapan Diri (self-disclosure)

BAB 5 : PERSEPSI SOSIAL (SOCIAL PERCEPTION)
A. Observasi : Elemen-elemen Persepsi Sosial
B. Komunikasi Nonverbal
C. Atribusi (Attribution)

BAB 6 : KOGNISI SOSIAL (SOCIAL COGNITION)
A. Skema
B. Heuristik (heuristics) Dan Pemrosesan Otomatis 

C. Sumber-sumber Kesalahan Dalam Kognisi Sosial

BAB 7 : SIKAP (ATTITUDES)

\author{
A. Pengertian Sikap \\ B. Komponen Sikap \\ C. Fungsi Sikap \\ D. Pembentukan dan Perubahan Sikap \\ E. Pengukuran Sikap \\ F. Hubungan Sikap dan Tingkah Laku \\ G. Komunikasi Persuasif \\ H. Teori Disonansi Kognitif
}

BAB 8 : DAYA TARIK INTERPERSONAL DAN HUBUNGAN ERAT

A. Mengapa Seseorang Berhubungan Dengan Orang Lain ?

B. Daya Tarik Interpersonal (Interpersonal Attraction)

C. Hubungan Erat atau Akrab (Close Relationship)

BIODATA PENULIS

DAFTAR PUSTAKA 


\section{BAB 1}

\section{PENDAHULUAN}

\section{Capaian Pembelajaran Mata Kuliah :}

a. Aspek Sikap dan Tata Nilai :

(1) Bertakwa kepada Tuhan Yang Maha Esa dan mampu menunjukkan sikap religious

(2) Berkontribusi dalam peningkatan mutu kehidupan bermasyarakat, berbangsa, bernegara, dan kemajuan peradaban berdasarkan Pancasila

(3) Menghargai keanekaragaman budaya, pandangan, agama dan kepercayaan serta pendapat atau temuan orisinal orang lain

b. Aspek Ketrampilan Umum :

(1) Menguasai konsep teoritis hubungan manusia dengan lingkungan sosialnya

(2) Menguasai konsep teoritik komunikasi antar pribadi dan komunikasi massa

c. Aspek Ketrampilan Khusus :

Mampu menerapkan pemikiran logis, kritis, sistematis, dan inovatif dalam konteks pengembangan atau implementasi ilmu pengetahuan dan teknologi yang memperhatikan dan menerapkan nilai humaniora

d. Aspek Penguasaan Pengetahuan :

Mampu memahami dan menjelaskan peranan Psikologi Sosial dalam proses interaksi sosial, serta menerapkan dalam menyelesaikan permasalahan sosial. 


\section{A. Sejarah Perkembangan Psikologi Sosial}

Masa Kelahiran dan Pertumbuhan Psikologi Sosial (Tahun 1880 hingga 1935).

Sebagai salah satu cabang ilmu dalam psikologi, lahirnya psikologi sosial tidak bisa dilepaskan dari filsafat. Ahli filsafat terkenal Plato mengajukan beberapa pemikiran tajam terkait permasalahan dalam psikologi sosial. Namun psikologi sosial belum menjadi sebuah disiplin ilmu hingga akhir abad ke-19 (1897-1898). Saat itu Norman Triplett seorang ahli psikologi dari Amerika mempublikasikan artikel pertama hasil dari penelitiannya di bidang psikologi sosial. Triplett melakukan sebuah penelitian dengan rancangan eksperimen tentang bagaimana pengaruh konteks sosial terhadap perilaku individu. Penelitian tersebut dilakukan setelah Triplett melakukan observasi pada pengendara sepeda yang mengayuh sepedanya lebih cepat ketika bersepeda bersama-sama orang lain dibandingkan ketika bersepeda sendirian. Eksperimen itulah yang menandai kelahiran Psikologi Sosial sebagai sebuah ilmu pengetahuan (Kassin, et. al., 2008).

Tahun 1880-an Max Ringelmann seorang insinyur pertanian dari Perancis melakukan penelitian dengan topik yang sama, yaitu bagaimana pengaruh kehadiran orang lain terhadap performa individu, namun hasil penelitiannya tidak dipublikasikan hingga tahun 1913. Bertolak belakang dengan Triplett, hasil studi Ringelmann menunjukkan bahwa performa individu sering buruk pada tugas yang sederhana ketika mereka bekerja bersama-sama orang lain.

Selain kedua tokoh di atas, kontribusi lain yang berpengaruh terhadap kelahiran psikologi sosial adalah terbitnya tiga buku pertama yang ditulis oleh ahli psikologi Inggris bernama William McDougall (1908) dan dua orang dari Amerika yaitu Edward Ross (1908) dan Floyd Allport (1924). Dalam bukunya Allport 
dengan fokus pada interkasi antar individu dan konteks sosial, serta menekankan penggunaan eksperimen dan metode ilmiah, semakin menegakkan berdirinya psikologi sosial sebagai sebuah disiplin ilmu. Ketiga penulis ini menegaskan kehadiran sebuah pendekatan baru dalam psikologi sosial, yaitu menekankan aspek-aspek sosial yang berpengaruh terhadap perilaku manusia. Dari sinilah psikologi sosial lahir (Kassin, et. al., 2008).

\section{Masa Kemajuan Yang Besar (Tahun 1930 hingga 1950)}

Salah satu tokoh yang lahir pada masa ini adalah Muzafer Sherif, lahir di Turki dan menyelesaikan pendidikan di Turki dan Amerika Serikat. Sherif menyadari bahwa perilaku individu dipenaruhi oleh lingkungan sosialnya. Pada tahun 1938, Sherif mempublikasikan studi besar tentang pengaruh sosial. la melakukan studi tentang konformitas dan melakukan penelitian dengan metode eksperimen. Eksperimen yang dilakukan tentang ilusi visual berupa sebuah titik sinar yang sebenarnya berhenti namun terlihat bergerak. Ketika individu melihat sendiri, titik tersebut dipersepsi berhenti, namun ketika melihat bersama-sama kelompoknya, titik itu dipersepsi bergerak. Titik itu sebetulnya tidak pernah berubah, namun pendapat kelompok telah mengubah pendapat individu bahwa seakan-akan titik tersebut bergerak (Suryanto, et. al., 2012).

Penelitian Sherif ini mendorong perkembangan psikologi sosial semakin pesat. Riset yang dilakukan Sherif menginspirasi studi yang lebih kompleks tentang perilaku manusia sebagai akibat dari pengaruh sosial dalam situasi ilmiah. Pada masa ini banyak lahir topik-topik besar dalam psikologi sosial.

Kontributor besar lainnya dalam psikologi sosial adalah Kurt Lewin. Lewin merupakan seorang tokoh besar dan kreatif yang konsep-konsepnya memiliki pengaruh besar di kehidupan praktis. 
Beberapa prinsip dasar dalam psikologi sosial yang ditetapkan oleh Lewin yaitu, pertama bahwa apa yang kita lakukan tergantung pada persepsi dan interpretasi kita tentang lingkungan sekitar. Orang yang berbeda dapat mempersepsi secara berbeda meski situasi yang dihadapi sama. Kedua, Perilaku individu merupakan fungsi dari interaksi antara individu dan lingkungannya, $B=f(P . E)$. Teori Lewin ini kemudian dikenal sebagai Teori atau Perspektif Interaksionis, yang melihat perilaku manusia merupakan hasil dari faktor personal (pribadi) dan faktor lingkungan (Blass, 1991). Ketiga, melalui teori-teori dan penelitiannya, psikologi sosial bisa diterapkan untuk menyelesaikan persoalan-persoalan praktis dalam kehidupan sosial. Oleh karena itu, terapan psikologi sosial semakin meluas di berbagai bidang kehidupan, antara lain bidang periklanan, bisnis, pendidikan, perlindungan lingkungan, kesehatan, hokum, politik, kebijakan publik, agama, dan olahraga (Kassin, et. al., 2008)

\section{Masa Kepercayaan Dan Krisis (Tahun 1960 hingga 1970)}

Pada masa ini, psikologi sosial melakukan ekspansi yang luar biasa. Diawali oleh Stanley Milgram (awal hingga pertengahan tahun 1960), melakukan penelitian dengan metode eksperimen, yang diinspirasi oleh adanya kepatuhan yang merusak (destructive obedience) oleh perwira Nazi dan warga sipil pada Perang Dunia II.

Para ahli psikologi sosial mulai mempelajari bagaimana orang berpikir dan merasakan tentang dirinya dan orang lain. Mereka telah mempelajari interaksi individu dalam kelompok dan persoalan-persoalan sosial seperti mengapa seseorang tidak berhasil menolong orang lain dalam kondisi distress. Mereka juga menguji tentang agresi, daya tarik interpersonal, dan stres. Oleh karena itu, masa ini dikatakan sebagai masa yang sangat produktif (Kassin, et. al., 2008). 
Ironisnya, pada masa ini juga terjadi krisis dan perdebatan yang tajam. Perdebatan yang banyak terjadi merupakan reaksi atas penggunaan metode eksperimen sebagai metode penelitian dalam psikologi sosial. Para ahli psikologi sosial yang mempertanyakan penggunaan metode eksperimen melihat bahwa pelaksanaannya tidak etis (Kelman, 1967), ekspektasi eksperimenter mempengaruhi perilaku partisipan eksperimen (Orne, 1962; Rosenthal, 1976), serta teori-teori yang diuji di dalam laboratorium terbatas pada aspek historis dan budaya. Sementara itu beberapa ahli yang mendukung metode eksperimen menegaskan bahwa prosedur yang mereka lakukan sudah etis, hasilnya valid, dan prinsip-prinsip teorinya dapat diaplikasikan (McGuire, 1967). Untuk sementara, psikologi sosial terpecah menjadi dua kelompok (Kassin, et. al., 2008).

\section{Masa Pluralisme (pertengahan tahun 1970 hingga sekarang)}

Pertentangan di antara dua kelompok semakin menujukkan kemenangannya. Beberapa standar etis dalam penelitian disusun secara teliti dan setepat-tepatnya untuk menjaga munculnya bias dan lebih memperhatikan kemungkinan terjadinya perbedaan antar budaya yang mempengaruhi perilaku individu. Laboratorium eksperimen justru semakin berkembang (Kassin, et. al., 2008).

Pluralisme dalam psikologi sosial terkait penggunaan beragam metode dalam penelitiannya karena aspek perilaku manusia yang akan dikaji juga semakin bervariasi. Beberapa penelitian psikologi sosial yang dikenal sebagai "hot perspective," memfokuskan peranan emosi dan motivasi sebagai faktor penentu (determinan) pada munculnya pikiran dan perilaku individu. Sementara area penelitian lain dikenal sebagai "cold perspective", memperhatikan peranan kognisi, mengkaji bagaimana pikiran 
seseorang berpengaruh terhadap perasaannya, keinginannya, dan tindakannya. Tentunya para ahli psikologi sosial mengkaji perilaku berdasarkan kedua perspektif yang saling mempengaruhi satu sama lain. Integrasi dari berbagai perspektif yang berbeda merupakan karakteristik pluralisme dari psikologi sosial yang menyebar luas hingga beberapa tahun terakhir (Kassin, et. al, 2008).

Pada masa ini juga berkembang teori kognisi sosial sebagai salah satu kajian psikologi sosial. Kognisi sosial mengkaji bagaimana seseorang mempersepsi, mengingat, dan menginterpretasi informasi tentang dirinya maupun orang lain (Suryanto, et. al., 2012).

Sumber lain yang menandai pluralisme dalam psikologi sosial yaitu berkembangnya perspektif secara internasional maupun multicultural. Jika sebelumnya para ahli psikologi sosial berasal dari USA dan Kanada, maka pada masa ini ahli psikologi sosial banyak bermunculan dari berbagai benua, baik di Inggris, Negara-negara Eropa, Afrika, Asia, dan Amerika Latin. Pada awalnya psikologi sosial dikenal dengan monokultural, maka dengan menyebarnya ke berbagai penjuru dunia, psikologi sosial lebih bersifat multikultural (Suryanto, et. al., 2012).

\section{B. Pengertian Psikologi Sosial}

Psikologi sosial merupakan studi ilmiah tentang bagaimana individu berpikir, merasa, dan berperilaku dalam konteks sosial (Kassin, et. al., 2008). Berdasarkan definisi ini, terdapat beberapa poin penting dari psikologi sosial sebagai berikut :

\section{Studi ilmiah.}

Banyak cara untuk memahami bagaimana individu berpikir, merasa, dan berperilaku, bisa melalui novel, film, sejarah, dan 
filsafat. Lalu, apa yang membedakan dengan psikologi sosial ? Psikologi sosial menggunakan metode ilmiah yang sistematis, seperti observasi yang sistematis, deskripsi dan pengukuran untuk mempelajari kondisi manusia.

\section{Bagaimana individu berpikir, merasa, dan berperilaku.}

Psikologi sosial fokus pada beragam topik yang luar biasa. Selain psikologi sosial, beberapa studi ilmiah juga menggunakan metode ilmiah untuk mempelajari tentang manusia, seperti antropologi, ilmu komunikasi, ilmu ekonomi, ilmu politik, dan sosiologi. Semua bidang studi ini, termasuk psikologi sosial digolongkan sebagai ilmu-ilmu sosial. Namun psikologi sosial memiliki kekhasan, yaitu mengkaji secara mendalam sikap dan konteks, seperti sikap individu saat menjadi bagian dari sekelompok orang, tau bagaimana sikap individu dipengaruhi oleh teman sebaya atau mood (Kassin, Fein, \& Markus, 2008). Psikologi sosial mempelajari perilaku yang bervariasi dalam setting yang juga berbeda. Tingkat analisis psikologi sosial berbeda dengan ilmu sosial yang lain, yaitu fokus pada aspek psikologi dari individu. Meskipun psikologi sosial juga mempelajari tentang kelompok, namun penekanannya pada perilaku individu dalam konteks kelompok.

\section{Dalam konteks atau situasi sosial.}

"Sosial" inilah yang membedakan psikologi sosial dengan cabang psikologi lainnya. Situasi sosial menceriminkan tempat perilaku terjadi. Dalam menyusun prinsip-prinsip secara umum dari perilaku manusia, psikologi sosial menguji faktor-faktor non sosial (misalnya cuaca panas) dan faktor sosial (seperti pengaruh sosial dan interaksi sosial) yang mempengaruhi pikiran, emosi, motivasi, dan perilaku (Kassin, et. al., 2008). 
Kenrick menyatakan bahwa psikologi sosial merupakan studi ilmiah yang mempelajari tentang bagaimana seseorang berpikir, berperasaan, dan berperilaku yang dipengaruhi oleh orang lain (Suryanto, et. al., 2012). Kenrick menekankan orang lain sebagai faktor yang mempengaruhi perilaku individu, sedangkan Kassin, dkk. menekankan situasi sosial sebagai setting terjadinya perilaku.

Baron dan Byrne (2003) menyatakan bahwa psikologi sosial merupakan ilmu pengetahuan yang berusaha memahami asal-usul dan penyebab terjadinya perilaku dan pemikiran individu dalam konteks sosial. Situasi sosial adalah situasi dimana terdapat kehadiran orang lain secara nyata maupun imajinasi.

Berdasarkan beberapa definisi di atas dapat disimpulkan bahwa psikologi sosial merupakan studi ilmiah, dengan fokus kajian tentang bagaimana pikiran, perasaan, dan perilaku seseorang dalam situasi sosial.

\section{Faktor-faktor Penyebab Pemikiran dan Perilaku Sosial}

Menurut Baron dan Byrne (2003) terdapat beberapa faktor yang mendorong munculnya pemikiran dan perilaku sosial pada individu, sebagai berikut :

\section{Perilaku dan karakter orang lain.}

Perilaku orang lain sering mempengaruhi pemikiran dan perilaku individu terhadap orang orang lain. Demikian juga halnya dengan karakter orang lain. Individu sering bereaksi terhadap karakteristik orang lain yang kasat mata, seperti penampilannya. Hasil penelitian Hassin dan Trope (2000) menujukkan bahwa individu tidak bisa mengabaikan penampilan orang lain, bahkan ketika secara sadar mencoba untuk mengabaikannya. Berikut eksperimen yang dilakukan oleh Hassin dan Trope. Peneliti memperlihatkan foto orang- 
orang yang dijadikan calon karyawan untuk bagian pekerjaan tertentu (seperti administrasi, pemeriksa mata, tukang listrik) kepada partisipan penelitian. Informasi tentang latar belakang para calon karyawan tersebut juga diberikan. Tugas para partisipan adalah menilai kecocokan orang-orang yang ada di foto tersebut dengan pada pekerjaan tertentu. Sebagian partisipan diminta untuk mengabaikan foto ketika membuat keputusan, sedangkan sebagian lainnya tidak diminta untuk mengabaikan. Hasilnya menunjukkan bahwa orang-orang dalam foto yang terlihat sebagai pekerja pada pekerjaan tertentu menerima penilaian yang lebih tinggi dibandingkan yang tidak. Bahkan hal ini juga berlaku pada partisipan yang diminta untuk mengabaikan foto dalam memberikan penilaian. Temuan ini menunjukkan bahwa reaksi individu terhadap orang lain dipengaruhi oleh penampilan luarnya.

\section{Proses kognitif.}

Cara berpikir dan perilaku individu terhadap orang lain dipengaruhi oleh ingatan individu tentang perilaku orang tersebut di masa lalu dan penyimpulan tentang kebenaran alasannya. Proses kognitif seperti ingatan dan penalaran (proses yang mendasari pikiran, keyakinan, ide, dan penilaian tentang orang lain yang dimiliki individu) memainkan peran penting dalam pemikiran dan perilaku sosial (Dayakisni \& Hudaniah, 2003).

\section{Variabel lingkungan (ekologi)}

Merupakan pengaruh lingkungan fisik. Hasil penelitian menunjukkan bahwa lingkungan fisik seperti cuaca, bau, dan kepadatan, mempengaruhi perasaan, pikiran, dan perilaku individu terhadap orang lain. Menurut Anderson, Bushman, \& Groom (1997) apakah individu mudah marah dan agresif ketika cuaca sedang panas dibandingkan ketika cuacanya sejuk dan 
nyaman ? Apakah bau yang harum mendorong individu lebih tertarik atau suka menolong orang lain ?

\section{Konteks budaya}

Perilaku sosial sangat dipengaruhi oleh norma-norma sosial (aturan sosial tentang bagaimana seharusnya individu berperilaku dalam situasi tertentu), keanggotaan individu dalam kelompok, dan perubahan nilai-nilai sosial. Perilaku sosial dipengaruhi oleh konteks kebudayaan dimana perilaku sosial terjadi.

\section{Faktor biologis}

Merupakan warisan sifat-sifat dan genetik yang relevan dengan perilaku sosial. Bidang psikologi evolusioner memandang bahwa faktor biologis memainkan peran penting dalam perilaku sosial (Buss, 1995; Buss \& Shackelford, 1997). Misalnya dalam hal memilih pasangan. Mengapa individu memandang beberapa orang itu menarik yang kemudian dipilih menjadi pasangannya ? Menurut perspektif evolusi, hal ini disebabkan karena karakteristik yang menarik (seperti bentuk wajah simetris, bentuk tubuh bagus, kulit bersih, rambut indah) dikaitkan dengan kapasitas reproduksi. Artinya bahwa karakteristik luar dari individu yang bisa dilihat tersebut dianggap mewakili kesehatan dan kekuatan dalam yang tidak bisa dilihat. Jadi, pemilihan pasangan yang memiliki karakteristik seperti ini, meningkatkan potensi bahwa individu tersebut akan berhasil dalam reproduksi. Hal inilah yang kemudian mempengaruhi pilihan individu dalam menentukan pasangan yang didasarkan pada aspek-aspek penampilan atau karakteristik luar yang dimiliki oleh seseorang. Para ahli psikologi sosial di bidang evolusi menekankan bahwa kecenderungan atau predisposisi perilaku sosial ini bisa terjadi 
atau mungkin juga tidak bisa terjadi dalam realitas, bergantung pada lingkungan dimana individu tinggal.

\section{Ruang Lingkup Psikologi Sosial}

Fieldman (dalam Dayakisni \& Hudaniah, 2003) menekankan bahwa psikologi sosial memiliki lingkup yang luas, seperti yang diuraikan pada tabel berikut ini :

\section{Tabel 1.1. Topik-topik Umum Psikologi Sosial}

\begin{tabular}{|c|c|c|}
\hline Kategori & Topik & $\begin{array}{l}\text { Contoh pertanyaan khusus yang dapat } \\
\text { diselidiki dalam topik tersebut }\end{array}$ \\
\hline \multirow[t]{8}{*}{$\begin{array}{l}\text { Proses } \\
\text { individual }\end{array}$} & $\begin{array}{l}\text { Prestasi dan } \\
\text { performance tugas }\end{array}$ & $\begin{array}{l}\text { Faktor-faktor apa yang menentukan } \\
\text { prestasi dan motivasi terkait performance } \\
\text { sekolah? }\end{array}$ \\
\hline & $\begin{array}{l}\text { Sikap dan perubahan } \\
\text { sikap }\end{array}$ & $\begin{array}{l}\text { Apakah ada hubungan antara sikap politik } \\
\text { dan tingkah laku dalam pemungutan suara } \\
\text { ? }\end{array}$ \\
\hline & Atribusi & $\begin{array}{l}\text { Faktor-faktor apa yang mendorong } \\
\text { individu melakukan atribusi terhadap } \\
\text { tingkah laku individu lain? }\end{array}$ \\
\hline & Proses kognitif & $\begin{array}{l}\text { Bagaimana individu menggolongkan dan } \\
\text { mengkategorikan karakteristik } \\
\text { kepribadian orang lain ? }\end{array}$ \\
\hline & Disonansi & $\begin{array}{l}\text { Ketika individu dibuat untuk bertindak } \\
\text { yang bertentangan dengan apa yang dia } \\
\text { percayai, apakah sikap individu tersebut } \\
\text { berubah? }\end{array}$ \\
\hline & Persepsi sosial & $\begin{array}{l}\text { Bagaimana individu menggabungkan sifat- } \\
\text { sifat kepribadian individu lain untuk } \\
\text { membentuk sebuah kesan secara } \\
\text { keseluruhan tentang individu tersebut? }\end{array}$ \\
\hline & $\begin{array}{l}\text { Perkembangan sosial } \\
\text { dan kepribadian }\end{array}$ & $\begin{array}{l}\text { Faktor-faktor apakah pada masa kecil yang } \\
\text { bisa menjadi prediktor dalam masa } \\
\text { dewasa? }\end{array}$ \\
\hline & $\begin{array}{l}\text { Stres, emosi, dan } \\
\text { arousal (kebangkitan) }\end{array}$ & $\begin{array}{l}\text { Faktor-faktor apa kah yang membuat } \\
\text { kebangkitan nafsu (gairah seksual)? }\end{array}$ \\
\hline \multirow[t]{3}{*}{$\begin{array}{l}\text { Proses } \\
\text { interpersonal }\end{array}$} & Agresi & $\begin{array}{l}\text { Apakah tayangan kekerasan di televisi bisa } \\
\text { meningkatkan agresi? }\end{array}$ \\
\hline & Daya tarik dan afiliasi & $\begin{array}{l}\text { Bagaimana daya tarik fisik seseorang } \\
\text { mempengaruhi cara perlakuan orang lain } \\
\text { terhadap dirinya? }\end{array}$ \\
\hline & $\begin{array}{l}\text { Bargaining (tawar- } \\
\text { menawar) dan koalisi }\end{array}$ & $\begin{array}{l}\text { Strategi penawaran apakah yang baik } \\
\text { untuk menjual mobil bekas? }\end{array}$ \\
\hline
\end{tabular}




\begin{tabular}{|c|c|c|}
\hline & $\begin{array}{l}\text { Konformitas dan } \\
\text { kepatuhan } \\
\text { (compliance) }\end{array}$ & $\begin{array}{l}\text { Mengapa individu konform dengan } \\
\text { pendapat orang lain? }\end{array}$ \\
\hline & $\begin{array}{l}\text { Persamaan, keadilan, } \\
\text { dan pertukaran sosial }\end{array}$ & $\begin{array}{l}\text { Pengadilan adil apakah yang diperhatikan } \\
\text { individu? }\end{array}$ \\
\hline & Pertolongan (helping) & $\begin{array}{l}\text { Situasi darurat seperti apakah penonton } \\
\text { (bystander) ikut terlibat menolong? }\end{array}$ \\
\hline & Komunikasi non-verbal & $\begin{array}{l}\text { Apakah individu lain bisa menebak emosi } \\
\text { orang lain secara akurat melalui tingkah } \\
\text { laku non-verbal ? }\end{array}$ \\
\hline & $\begin{array}{l}\text { Peranan dan } \\
\text { perbedaan seks (jenis } \\
\text { kelamin) }\end{array}$ & $\begin{array}{l}\text { Apakah wanita lebih konform } \\
\text { dibandingkan pria? }\end{array}$ \\
\hline & Pengaruh sosial & $\begin{array}{l}\text { Bagaimana minoritas mampu } \\
\text { mempengaruhi mayoritas dalam sebuah } \\
\text { kelompok? }\end{array}$ \\
\hline & Interaksi sosial & $\begin{array}{l}\text { Mengapa individu menyukai kehadiran } \\
\text { orang lain saat dia sedang bingung atau } \\
\text { gelisah? }\end{array}$ \\
\hline \multirow[t]{5}{*}{$\begin{array}{l}\text { Proses } \\
\text { kelompok }\end{array}$} & $\begin{array}{l}\text { Riset cross-cultural } \\
\text { (lintas budaya) }\end{array}$ & $\begin{array}{l}\text { Apakah orang Jepang memiliki sistem } \\
\text { manajemen yang paling unggul ? }\end{array}$ \\
\hline & $\begin{array}{l}\text { Crowding dan jarak } \\
\text { interpersonal }\end{array}$ & $\begin{array}{l}\text { Mengapa performance individu menurun } \\
\text { ketika berada dalam situasi ramai ? }\end{array}$ \\
\hline & $\begin{array}{l}\text { Psikologi lingkungan } \\
\text { dan kependudukan }\end{array}$ & $\begin{array}{l}\text { Bagaimana gedung yang terbaik dapat } \\
\text { didesain untuk meningkatkan kepuasan } \\
\text { konsumen? }\end{array}$ \\
\hline & Proses kelompok & $\begin{array}{l}\text { Apakah keputusan yang dibuat kelompok } \\
\text { lebih baik daripada keputusan yang dibuat } \\
\text { oleh individu? }\end{array}$ \\
\hline & Isu etnis dan rasial & $\begin{array}{l}\text { Apakah pembauran bisa mengurangi } \\
\text { prasangka sosial ? }\end{array}$ \\
\hline
\end{tabular}

Menurut Vaughan dan Hogg (dalam Sarwono \& Meinarno, 2009), terdapat sedikitnya empat tingkatan analisis dalam psikologi sosial sebagai berikut :

1. Intrapersonal, merupakan proses psikologis yang terjadi di dalam diri individu dalam proses pengorganisasian pengalaman dan lingkungan sosialnya. Hal ini bisa dilihat dalam penelitian tentang keseimbangan kognitif (cognitive balance) dan skema kognitif.

2. Interpersonal dan situasional, merupakan tingkatan analisis pada interaksi antarindividu dalam situasi tertentu, dengan 
fokus penelitiannya adalah satu situasi dan kondisi yang terjadi pada masing-masing individu. Penelitian tentang hal ini adalah atribusi dan penggunaan matriks permainan.

3. Posisional, analisis terhadap interaksi antarindividu dalam situasi tertentu, dengan memperhatikan peran dari posisi sosial yang ada (seperti status, identitas). Penelitian tentang hal ini bisa dilihat pada penelitian yang bertema kekuasaan (power) dan identitas sosial.

4. Ideologis, merupakan analisis terhadap interaksi antarindividu yang mempertimbangkan keyakinan sosial dan hubungan sosial antarkelompok. Hal ini bisa dilihat pada persoalan tentang representasi sosial, identitas sosial, pengaruh kelompok minoritas, serta peran kebudayaan dan norma.

Sementara menurut Michener dan Delamater (dalam Dayakisni \& Hudaniah, 2003), terdapat empat fokus utama dalam psikologi sosial sebagai berikut :

1. Pengaruh individu terhadap individu lain

2. Pengaruh kelompok terhadap individu-individu anggotanya

3. Pengaruh individu anggota kelompok terhadap kelompoknya sendiri

4. Pengaruh satu kelompok terhadap kelompok lainnya

\section{E. Kedudukan Psikologi Sosial Dengan Ilmu-ilmu Sosial Lain}

Psikologi sosial memiliki keterkaitan dengan bidang ilmu tertentu, terkait beberapa topik atau isu atau kajian tertentu (Kassin, et. al., 2008).

\section{Psikologi Sosial dengan Sosiologi dan Antropologi}

Beberapa isu atau topik yang dibahas dalam psikologi sosial juga menjadi kajian oleh para ahli sosiologi, seperti kekerasan 
(violence), prasangka (prejudice), perbedaan budaya, dan pernikahan. Meskipun demikian, perlu diperhatikan bahwa sosiologi lebih menekankan kajiannya pada tingkatan kelompok, sedangkan fokus kajian psikologi sosial terletak pada tingkatan individu (Kassin, et. al., 2008).

Sebagai tambahan, para ahli sosiologi sering mempelajari tentang hubungan antara perilaku individu dan variabel kemasyarakatan, seperti kelas sosial. Sebaliknya, ahli psikologi sosial lebih mengkaji pada hubungan antara perilaku individu dan lebih spesifik lagi yaitu variabel perantara, seperti perubahan suasana hati dan paparan model perilaku tertentu (Kassin, et. al., 2008). Perlu diperhatikan bahwa ciri khas dari psikologi sosial adalah memfokuskan pada individu daripada kelompok atau unit atau analisis kemasyarakatan yang memang menjadi fokus kajian sosiologi (Dayakisni \& Hudaniah, 2003).

Sementara itu, mempelajari tentang perilaku manusia dalam suatu sistem sosial, maka pengaruh faktor budaya tidak bisa dilepaskan. Di sinilah psikologi sosial berkaitan erat dengan antropologi. Menurut Bonner, perilaku sosial selamanya terjadi di dalam suprastruktur budaya tertentu (Sarwono, 2002).

\section{Psikologi Sosial dan Psikologi Klinis}

Psikologi klinis berusaha memahami dan menyembuhkan orang-orang yang mengalami gangguan psikologi. Psikologi sosial tidak menekankan pada gangguan yang dialami individu, namun lebih fokus pada bagaimana cara individu berpikir, merasa, berperilaku, dan saling mempengaruhi antarindividu. Bagaimanapun juga, terdapat irisan atau kesamaan antara psikologi klinis dan psikologi sosial. Keduanya berupaya mengatasi orangorang dengan kecemasan atau tekanan dalam situasi sosial, bagaimana individu mengalami depresi dan tidak saat mereka 
mempersepsi atau bertindak terhadap orang lain, atau bagaimana ketika individu menjadi korban bullying atau menjadi sasaran stereotip dari orang lain, dimana hal ini bisa mempengaruhi kesehatan individu dan perasaan harga dirinya (Kassin, et. al., 2008).

\section{Psikologi Sosial dan Psikologi Kepribadian}

Baik psikologi sosial maupun psikologi kepribadian samasama menitikberatkan pada individu serta pikiran, perasaan, dan perilakunya. Yang perlu diperhatikan adalah psikologi kepribadian berusaha untuk memahami perbedaan antar individu yang relatif menetap di berbagai situasi, sedangkan psikologi sosial berusaha untuk memahami bagaimana faktor sosial berpengaruh terhadap individu, meskipun kepribadian mereka berbeda (Kassin, et. al., 2008).

Dengan kata lain, para ahli psikologi kepribadian tertarik pada konsistensi perbedaan situasi (Kassin, et. al., 2008). Mereka mungkin melontarkan pertanyaan "Apakah individu selalu ramah hampir sepanjang waktu, pada semua situasi ?" Sementara itu para ahli psikologi sosial tertarik pada bagaimana perbedaan situasi menyebabkan perbedaan perilaku. Mereka akan mengajukan pertanyaan "Apakah orang-orang secara umum lebih mungkin mencari sahabat saat mereka sedang cemas pada sebuah situasi dibandingkan ketika mereka sedang berada dalam keadaan santai ?"

Beberapa contoh di atas menunjukkan perbedaan di antara kedua bidang kajian, namun kenyataannya psikologi kepribadian dan psikologi sosial terkait erat (Kassin, et. al., 2008). Sebagai contoh, beberapa ahli psikologi sosial menjelaskan bagaimana menerima umpan balik negatif (faktor situasional) bisa memunculkan efek yang berbeda pada orang-orang yang memiliki 
harga diri tinggi atau rendah (faktor perbedaan individual), atau apakah bermain video kekerasan (faktor situasional) memicu agresifitas pada beberapa tipe anak-anak (faktor perbedaan individual).

\section{Psikologi Sosial dan Psikologi Kognitif}

Ahli psikologi kognitif mempelajari proses mental seperti berpikir, belajar, mengingat, dan membuat alasan. Ahli psikologi sosial seringkali tertarik mengkaji proses tersebut. Lebih spesifik, meskipun ahli psikologi sosial tertarik pada bagaimana orang berpikir, belajar, mengingat, dan membuat alasan, dengan mengutamakan berbagai informasi sosial dan bagaimana proses tersebut berkaitan dengan perilaku sosial (Kassin, et. al., 2008). 


\section{BAB 2}

\section{TEORI-TEORI DASAR PSIKOLOGI SOSIAL}

\section{Capaian Pembelajaran Mata Kuliah :}

a. Aspek Sikap dan Tata Nilai :

(1) Bertakwa kepada Tuhan Yang Maha Esa dan mampu menunjukkan sikap religious

(2) Berkontribusi dalam peningkatan mutu kehidupan bermasyarakat, berbangsa, bernegara, dan kemajuan peradaban berdasarkan Pancasila

(3) Menghargai keanekaragaman budaya, pandangan, agama dan kepercayaan serta pendapat atau temuan orisinal orang lain

b. Aspek Ketrampilan Umum :

(1) Menguasai konsep teoritis hubungan manusia dengan lingkungan sosialnya

(2) Menguasai konsep teoritik komunikasi antar pribadi dan komunikasi massa

c. Aspek Ketrampilan Khusus :

Mampu menerapkan pemikiran logis, kritis, sistematis, dan inovatif dalam konteks pengembangan atau implementasi ilmu pengetahuan dan teknologi yang memperhatikan dan menerapkan nilai humaniora

d. Aspek Penguasaan Pengetahuan :

Mampu memahami dan menjelaskan peranan Psikologi Sosial dalam proses interaksi sosial, serta menerapkan dalam menyelesaikan permasalahan sosial. 


\section{A. Perspektif Sosiokultural (The Sociocultural Perspective)}

Tahun 1908 lahir publikasi buku pertama dari dua buku yang berjudul Social Psychology, ditulis oleh ahli sosiologi bernama Edward Alsworth Ross. Ross melihat bahwa sumber utama dari perilaku sosial bukan berasal dari dalam diri individu melainkan dari kelompok sosial. Ross berpendapat bahwa orang-orang seringkali terbawa arus sosial, seperti penyebaran emosi dalam sebuah kerumunan (crowd) atau epidemik emosi religius. Ross memberikan contoh seperti insiden the Dutch tulip craze di tahun 1634. Pada kejadian ini, banyak orang menjual rumah dan tanahnya untuk membeli akar bunga tulip yang nilainya lebih mahal dari emas, namun akhirnya menjadi tidak berharga saat kegilaan (craze) ini berhenti (Kenrick, et al., 2002).

Fenomena bunga tulip ini pernah terjadi di Indonesia sekitar tahun 2000, saat ikan louhan yang dianggap pembawa berkah sehingga menyebabkan orang-orang membeli dengan harga berapapun mahalnya, bahkan ada orang yang membeli ikan tersebut seharga 25 juta rupiah. Harga itu tentunya sangat fantastis bagi masyarakat. Setelah orang-orang jenuh, sekitar akhir tahun 2003, ikan tersebut sudah tidak berharga lagi di pasaran (Suryanto, et. al., 2012).

Untuk menjelaskan fenomena "kegilaan" di atas, seperti banyaknya remaja yang pingsan atau maraknya bunuh diri, Ross lebih melihat pada unsur kelompok sebagai keseluruhan daripada unsur psyche (jiwa) individual anggota kelompok. Ross melihat bahwa bahwa kegilaan (craze) dan mode (fads) sebagai produk dari "pikiran massa" (mob mind) yang menyebabkan ketertarikan irasional dan hilangnya perasaan maupun pikiran individual karena adanya sugesti dan imitasi (Kenrick, et al., 2002).

Seperti Ross, ahli sosiologi lain yang bernama Sumner (1906) mengembangkan teorinya pada kelompok sosial yang lebih 
besar, dari kelompok tetangga menuju ke kelompok etnik dan kelompok partai politik. Teori ini terus berlanjut dalam perspektif sosiokultural modern, yang melihat bahwa prasangka seseorang, preferensi, dan persuasi politik disebabkan karena beberapa faktor, seperti nasionalitas, kelas sosial, dan tren sejarah yang berkembang. Teori sosiokultural fokus pada pentingnya norma sosial (social norms) atau aturan tentang perilaku yang sesuai. Perspektif ini berpusat pada konsep budaya (culture), dimana kita bisa mendefinsikan secara lebih luas sebagai keyakinan (belief), adat (customs), kebiasaan (habits) dan bahasa yang dikembangkan secara bersama-sama oleh orang-orang dalam waktu dan tempat tertentu. Menurut Smith et al., (dalam Kenrick, et al., 2002), budaya (culture) mencakup semua fitur lingkungan hasil rekayasa manusia, seperti fitur obyektif (rumah, baju) dan fitur subyektif (etika, nilai, kriteria untuk stylish). Seperti yang Anda lihat nanti, kajian tentang kelompok, budaya dan norma sosial berkembang sebagai peminatan utama dalam psikologi sosial.

\section{B. Perspektif Evolusioner (The Evolutionary Perspective)}

Para peneliti yang mengadopsi perspektif sosiokultural telah tertarik pada perbedaan perilaku dari satu budaya ke budaya selanjutnya . Namun sebagian peneliti lainnya lebih tertarik pada hal serupa, tidak hanya perbedaan budaya manusia melainkan juga mengkaji sekelompok binatang yang berbeda. Penekanan pada kesamaan ini bisa dilihat pada tahun 1908 dalam tulisan psikologi sosial oleh William McDougal, seorang ahli psikologi Inggris yang telah terlatih di bidang biologi. McDougal menekankan sebuah perspektif evolusioner (evolutionary perspective), yang melihat perlaku sosial manusia bersumber dari disposisi fisik dan psikologis yang membantu leluhur manusia untuk bertahan hidup dan melakukan reproduksi (Kenrick, et al., 2002). 
Ide awal teori ini adalah seleksi alam yang diungkapkan oleh Charles Darwin dalam teorinya tentang evolusi. Dengan seleksi alam, hanya spesies (manusia dan binatang) dengan karakteristik tertentu yang bisa bertahan hidup dan mempertahankan kelangsungan hidupnya melalui adaptasi. Seperti yang terjada pada seekor ikan lumba-lumba (mamalia) memiliki wajah seperti lembu namun kakinya menyerupai sirip karena ia hidup di dalam air, sehingga dengan cara seperti itu mereka mampu mempertahankan kelangsungan hidupnya untuk mempertahankan spesiesnya (Suryanto, et. al., 2012).

Brewer dan Buss (dalam Taylor, et. al., 2009) menekankan terdapat beberapa ide penting bagi psikologi sosial evolusioner. Pertama, banyak tendensi dan preferensi manusia merupakan hasil dari seleksi alam (dikenal sebagai evolved psychological mechanism). Tendensi dan preferensi ini bisa dilihat sebagai respon adaptif terhadap permasalahan spesifik yang pernah dialami leluhur manusia. Kedua, semua perilaku manusia merefleksikan pengaruh dari disposisi psikologis internal dan tuntutan situasi eksternal. Ketiga, manusia dilahirkan dan menghabiskan hidupnya dalam kelompok sosial yang saling bergantung. Konsekuensinya, banyak mekanisme perkembangan psikologis yang terkait dengan cara menjalin relasi dengan orang lain. Hal ini mencakup kebutuhan akan rasa memiliki dan takut diasingkan oleh kelompok, kemampuan bekerja sama dengan orang lain.

Pendekatan evolusioner McDougal pada psikologi sosial terbengkalai selama 50 tahun, karena sejak awal para ahli psikologi dan ahli biologi salah dalam memahami tentang bagaimana faktor biologis dan lingkungan berinteraksi satu sama lain. Sebuah kesalahan terjadi yang mengasumsikan bahwa evolusi hanya mampu menghasilkan instink yang inflexible yang dibawa sejak 
lahir dan bukan disebabkan oleh lingkungan. Buss et al., menjelaskan bahwa kebanyakan ahli evolusi dan perilaku saat ini percaya bahwa faktor biologis mempengaruhi manusia dan binatang lain yang selalu membuat mereka berfungsi dengan caracara yang lebih fleksibel dan responsif pada lingkungan (Kenrick, et al., 2002).

Perspektif evolusioner berdampak dalam beberapa teori psikologi sosial, seperti teori tentang instink, teori tentang pengaruh lingkungan, dan teori-teori yang berkaitan dengan kajian lintas budaya (cross-cultural comparison).

\section{Perspektif Belajar Sosial (The Social Learning Perspective)}

Selama beberapa dekade setelah tahun 1908, kelompok yang mengikuti perspektif Ross dan pendekatan evolusioner McDougal mengalami penurunan popularitas (Kenrick, et al., 2002). Sebagai gantinya, banyak ahli psikologi beralih ke perspektif belajar sosial (the social learning perspective). Perspektif ini melihat bahwa perilaku sosial dipengaruhi oleh pengalaman belajar masa lalu individu dengan hadiah (reward) dan hukuman (punishment). Tokoh yang muncul di era ini yaitu Allport (1924) dan Hull (1934). Belajar bisa terjadi secara tidak langsung, saat individu mengamati individu lain terutama saat perilaku individu yang diamati tersebut memperoleh pujian atau perhatian. Serangkaian eksperimen yang menunjukkan tentang observational learning dilakukan oleh Bandura dan rekan-rekan sejawatnya, menunjukkan bagaimana anak-anak belajar meniru melakukan tindakan agresi setelah anakanak lain dan orang dewasa yang melakukan tindakan kekerasan (violence) memperoleh hadiah (reward).

Ide utama dalam teori ini adalah bahwa perilaku seseorang saat ini merupakan hasil dari pengalaman sebelumnya. Dalam situasi tertentu, seseorang belajar sebuah perilaku, seiring 
berjalannya waktu perilaku tersebut bisa menjadi kebiasaan. Ketika dia berhadapan dengan situasi serupa, orang tersebut cenderung berperilaku sesuai dengan kebiasaan yang pernah dilakukannya (Taylor, et. al., 2009). Pendekatan ini ketika diaplikasikan ke dalam perilaku sosial, oleh Albert Bandura (1977) dinamakan dengan social learning theory (teori belajar sosial). Lebih lanjut dijelaskan bahwa terdapat tiga mekanisme umum terjadinya proses belajar. Pertama adalah asosiasi atau pengkondisian klasik yang diperkenalkan oleh Pavlov. Kedua adalah penguatan (reinforcement), yang dipelajari oleh Skinner. Mekanisme ketiga adalah belajar dengan mengamati (observational learning).

Beberapa kasus kriminal yang terjadi di Indonesia, seperti pembunuhan dengan mutilasi menunjukkan bahwa perilaku ini (membunuh dengan memotong-motong tubuh korban) juga menjadi trend dalam tindak kriminalitas, mengingat dengan cara itu dapat menghilangkan jejak pelaku maupun korbannya, polisi pun membutuhkan waktu lama dalam menangani kasus tersebut. Sulitnya mengungkap kasus ini nampaknya memberikan pengalaman belajar yang menguatkan tindakan pembunuhan tersebut bagi pelaku (Suryanto, et. al., 2012).

Perspektif belajar sosial memiliki kemiripan dengan perspektif sosiokultural, dimana keduanya melihat bahwa perilaku sosial individu dipengaruhi oleh lingkungan sosialnya. Perbedaannya adalah pada perspektif belajar sosial lebih menekankan faktor pengalaman masa lalu yang dialami individu dan faktor keunikan dalam diri individu. Sedangkan perspektif sosiokultural melihat bahwa perilaku sosial disebabkan oleh lingkungan sosial yang lebih luas, seperti munculnya model pakaian, tatanan rambut, dan sebagainya (Suryanto, et. al., 2012).

Dalam psikologi sosial, perspektif ini telah digunakan untuk menjelaskan berbagai gejala perilaku sosial, seperti agresi, 
altruisme (prososial), daya tarik interpersonal, prasangka, dan pembentukan sikap. Perspektif ini banyak diminati oleh para ahli psikologi social karena menekankan pada tingkah laku yang bisa diselidiki secara alamiah (oyektif). Namun beberapa ahli merasa keberatan karena teori ini meminimalkan faktor-faktor internal yang mempengaruhi perilaku sosial, seperti proses berpikir (faktor kognisi) dan emosi.

\section{Perspektif Fenomenologi (The Phenomenological Perspective)}

Meskipun ketiga perspektif di atas memiliki perbedaan, namun ketiganya sama-sama menekankan pada lingkungan yang obyektif, dimana para pengikutnya melihat pada situasi nyata di lingkungan yang memicu munculnya instink, sugesti, atau kebiasaan yang dipelajari. Selama tahun 1930-1940, Kurt Lewin membawa perspektif yang berbeda dalam psikologi sosial, yang menekankan pada sudut pandang unik individu, atau fenomenologi (Kenrick, et al., 2002).

Meskipun menekankan pada interpretasi subyektif, bukan berarti Lewin menganggap tida ada realitas obyektif. Bahkan Lewin menekankan pada interaksi antara situasi dan interpretasi individu. Lewin mengakui bahwa interpretasi individu terhadap sebuah situasi berkaitan dengan tujuan (goal) saat kejadian itu. Misalnya, jika seorang remaja laki-laki yang gemar berkelahi, maka tabrakan yang tidak disengaja akan diinterpretasikan sebagai sebuah tindakan mendorong yang disengaja (tindakan agresi).

Seperti yang akan kita lihat nanti, bahwa teori Lewin yang menekankan pada tujuan (goal), interaksi antara faktor situasi dan individu (person), dan fenomenologi, semuanya berdampak besar pada bidang kajian psikologi sosial. Salah satu dampak dari pandangan Lewin adalah munculnya pandangan konstruktivis sosial modern (the modern social constructivist view), yang dikemukakan 
oleh Beall (1993) dan Gergen (1989). Menurut Hyde (1996), pandangan ini menjelaskan bahwa orang-orang tidak akan menemukan realitas sosial, justru mereka akan mengkonstruksi dan menyimpulkan berdasarkan pengalaman dan predisposisinya (kecenderungannya). Pandangan ini telah sering diterapkan untuk perbedaan laki-laki dan wanita. Beberapa pembagian peran dan tugas untuk maskulin dan feminine terlihat sewenang-wenang. Seperti mempertanyakan pantaskah seorang wanita sejati menjadi pemimpin politik?

\section{E. Perspektif Kognitif Sosial (The Social Cognitive Perspective)}

Jika perspektif fenomenologi lebih menekankan pada pengalaman dari dalam (inner experience) individu, maka perspektif kognisi sosial memiliki pemikiran bahwa ada hubungan yang dekat antara psikologi sosial dengan psikologi kognitif. Selama tahun 1970 hingga 1980 sebuah perkembangan pesat dari para ahli psikologi sosial yang mengadopsi sebuah perspektif kognitif sosial (social cognitive perspective), yang fokus pada proses individu untuk memperhatikan peristiwa-peristiwa sosial dan menginterpretasikannya, serta bagaimana pengalamanpengalaman individu disimpan dalam memori (Fiske \& Taylor, 1991).

Pendekatan kognitif menyatakan bahwa perilaku seseorang tergantung pada caranya dalam memahami situasi sosial. Kurt Lewin mengaplikasikan gagasan Gestalt ke psikologi sosial. Lewin menekankan pentingnya bagaimana individu memahami lingkungan sosial. Lebih lanjut Lewin menegaskan bahwa perilaku individu dipengaruhi oleh karakteristik personal individu (seperti kemampuan, kepribadian, disposisi genetik) dan pemahamannya tentang lingkungan sosial. 
Gagasan utama dalam perspektif kognitif ada dua. Pertama, individu cenderung mengelompokkan dan mengkategorikan objek secara spontan. Kedua, individu lebih fokus pada stimuli yang menonjol. Aplikasi langsung dari teori ini berupa penilitian tentang bagaimana individu membentuk kesan atas individu lain. Para ahli psikologi sosial menyelidiki tentang bagaimana pemahaman seseorang atas sifat-sifat individu yang digabungkan untuk membentuk kesan terhadap orang lain secara keseluruhan. Menurut Fiske dan Taylor, karya lain dari teori ini adalah teori atribusi, yaitu sebuah studi tentang bagaimana pengamat menyimpulkan penyebab tingkah lau orang lain, dan teori kognisi sosial (pemahaman sosial), yang menjelaskan tentang bagaimana orang-orang berpikir untuk memahami dunia sosial mereka (Dayakisni \& Hudaniah, 2003).

Berdasarkan penjelasan di atas disimpulkan bahwa pendekatan kognitif sosial berfokus pada persepsi saat sekarang, bukan terhadap pengalaman masa lalu (seperti yang menjadi fokus pada perspektif belajar sosial). Selain itu, perspektif ini lebih menekankan peranan penting persepsi atau interpretasi seseorang terhadap sebuah situasi.

\section{F. Perspektif Interaksionis Simbolik (The Symbolic Interactionist Frame)}

Menurut perspektif ini, masyarakat merupakan sebuah web komunikasi dan berinteraksi, dimana masing-masing orang saling mempengaruhi satu sama lain saat berperilaku. Interaksi adalah simbolik, yang artinya orang-orang berkembang dalam interaksi itu sendiri. Lingkungan untuk bertindak dan berinteraksi didefinisikan secara simbolik oleh individu. Orang-orag berinteraksi dengan menggunakan simbol-simbol yang dikembangkan dalam 
interaksi mereka, dan bertindak melalui komunikasi dari simbolsimbol ini (Delamater, 2006).

Perspektif ini berasumsi bahwa manusia membentuk makna melalui proses komunikasi. Perspektif ini berfokus pada pentingnya konsep diri dan persepsi individu berdasarkan interaksi dengan individu lain. Kehidupan sosial merupakan sebuah proses. Menurut Blumer, terdapat tiga asumsi dari perspektif ini. Pertama, manusia bertindak berdasarkan makna yang diberikan orang lain kepada mereka. Kedua, makna diciptakan dalam interaksi antar manusia. Ketiga, makna dimodifikasi melalui sebuah proses interpretasi dimana para pelaku berkomunikasi dengan diri mereka sendiri, melakukan seleksi, memeriksa, menyusun kembali, mentransformasikan, dan menggunakan makna untuk membentuk dan membimbing tindakan dan interaksi mereka dalam situasi yang mereka temukan sendiri.

Prinsip dari simbolisasi mengindikasikan bahwa peristiwa, kondisi, artefak, individu, agregasi individu dan berbagai fitur-fitur lainnya dari lingkungan manusia mengambil makna dan menjadi objek dari orang-orang yang menimbulkan perasaan dan tindakan.

\section{G. Teori Pernyataan Harapan (Expectations States Theory)}

Teori ini muncul sebagai sebuah semangat untuk menjelaskan beberapa temuan yang paling mencolok dari Robert $F$. Bales (1950) studi awal yang berpengaruh pada tingkah laku interpersonal dalam kelompok kecil. Teori ini berusaha untuk menjelaskan munculnya hierarki status dalam situasi dimana para pelaku berorientasi terhadap pencapaian tujuan atau tugas kolektif.

Menurut teori ini, budaya percaya tentang adanya kategori social pada level makro yang membawa dampak tingkah 
laku dan evaluasi pada level individu, yang bertindak untuk menghasilkan struktur status yang konsisten dengan keyakinan pada level makro sebelumnya. Struktur status di dalam kelompok dapat dianggap sebagai blok bangunan pada kebanyakan ketidakadilan struktural pada level makro dalam masyarakat. Dengan berfokus pada aturan tentang harapan diferensiasi kinerja (performance), teori ini menyediakan sebuah penjelasan bagaimana struktur penghargaan, pola tingkah laku, dan keyakinan level makro tentang sebuah perbedaan dalam kategori sosial menghasilkan efek serupa pada organisasi hierarkhi status interaksional, blok bangunan dalam stratifikasi masyarakat.

\section{H. Teori Pertukaran Sosial (Social Exchange Theory)}

Teori pertukaran sosial telah menjadi perspektif teori mayor dalam bidang psikologi sosial sejak diperkenalkan oleh Homans (1961), Blau (1964), dan Emerson (1962). Orientasi dasar dari teori ini didasarkan pada filosofis awal dan orientasi psikologi yang berasal dari utilitarianisme pada satu sisi dan aliran behavior pada sisi lainnya (Delamater, 2006). Homans mendefinisikan pertuakaran sosial sebagai sebuah pertukaran aktivitas, secara nyata maupun tidak nyata, dan lebih banyak atau sedikit penghargaan atau biaya, antara sedikitnya dua orang. Lebih lanjut Homans menjelaskan bahwa dalam interaksi sosial, terlihat bahwa manusia cenderung berinteraksi dengan individu-individu yang memberikan ganjaran (reward) seperti pujian, hak-hak istimewa, martabat, dan sebagainya, serta akan menghindari individuindividu yang menimbulkan kerugian (cost).

Prinsip dari teori pertukaran sosial didasarkan pada gagasan teori belajar dan teori pengambilan keputusan. Teori pertukaran sosial menganalisis interaksi antar individu berdasarkan keuntungan dan kerugian yang dipertukarkan individu. Interaksi 
interpersonal berdasarkan keuntungan dan kerugian bagi masingmasing pihak saat mereka berinteraksi (Taylor, et. al., 2009). 


\section{BAB 3}

\section{METODE PENELITIAN PSIKOLOGI SOSIAL}

\section{Capaian Pembelajaran Mata Kuliah :}

a. Aspek Sikap dan Tata Nilai :

(1) Bertakwa kepada Tuhan Yang Maha Esa dan mampu menunjukkan sikap religious

(2) Berkontribusi dalam peningkatan mutu kehidupan bermasyarakat, berbangsa, bernegara, dan kemajuan peradaban berdasarkan Pancasila

(3) Menghargai keanekaragaman budaya, pandangan, agama dan kepercayaan serta pendapat atau temuan orisinal orang lain

b. Aspek Ketrampilan Umum :

(1) Menguasai konsep teoritis hubungan manusia dengan lingkungan sosialnya

(2) Menguasai konsep teoritik komunikasi antar pribadi dan komunikasi massa

c. Aspek Ketrampilan Khusus :

Mampu menerapkan pemikiran logis, kritis, sistematis, dan inovatif dalam konteks pengembangan atau implementasi ilmu pengetahuan dan teknologi yang memperhatikan dan menerapkan nilai humaniora

d. Aspek Penguasaan Pengetahuan :

Mampu memahami dan menjelaskan peranan Psikologi Sosial dalam proses interaksi sosial, serta menerapkan dalam menyelesaikan permasalahan sosial. 
Psikologi merupakan ilmu yang mengkaji tentang perilaku manusia. Oleh karena itu, psikologi menjadi ilmu yang paling dekat dengan diri kita. Demikian juga dengan psikologi sosial yang kajiannya berkaitan erat dengan kehidupan sehari-hari kita, sehingga mudah dijelaskan hanya dengan pengetahuan umum atau akal sehat (common-sense). Menyimpulkan latar belakang sebuah perilaku berdasarkan akal sehat saja bisa menyebabkan terjadinya kesalahan penyimpulan dan bisa berlanjut pada kesalahan tindakan. Dengan adanya metode penelitian dalam psikologi sosial, bisa membantu mengembangkan alasan tentang peristiwa dalam kehidupan nyata yang tidak hanya mendasarkan pada akal sehat semata.

Psikologi sosial merupakan ilmu empiris, artinya bahwa para ahli psikologi sosial menggunakan metode ilmiah yang sistematis untuk mengumpulkan berbagai informasi tentang kehidupan sosial dan untuk menguji kegunaan suatu teori. Menurut Kassin, et. al., (2008), menjelaskan bahwa penelitian psikologi sosial memiliki empat tujuan sebagai berikut :

a. Deskripsi, yaitu memberikan deskripsi tentang perilaku sosial agar para ahli psikologi sosial bisa membuat generalisasi yang reliabel tentang bagaimana orang bertindak di berbagai setting sosial. Misalnya, apakah pria lebih agresif dibandingkan wanita ?

b. Analisis kausal, yaitu bertujuan untuk mengetahui hubungan sebab akibat. Misalnya, apakah iklan TV mampu mempengaruhi sikap seseorang dalam pemilu?

c. Penyusunan teori, yaitu menyusun teori perilaku sosial yang membantu para ahli psikologi memahami alasan dari perilaku seseorang.

d. Aplikasi, yaitu hasil penelitian psikologi sosial dapat diaplikasikan untuk mengatasi permasalahan sosial sehari-hari. 


\section{A. Membangun Ide Penelitian (Mengawali Proses Penelitian)}

Proses penelitian diawali dengan adanya ide atau gagasan penelitian, menyempurnakannya, menguji kebenaran ideide tersebut, dan menginterpretasikan makna dari hasil penelitian yang ditemukan (Kassin, et. al., 2008). Pada tahap awal untuk memulai sebuah penelitian, langkah-langkah yang dilakukan sebagai berikut :

1. Setiap penelitian psikologi sosial selalu diawali dengan sebuah pertanyaan dan pertanyan tersebut bisa muncul dari manapun, berdasarkan hasil pengamatan sehari-hari. Seperti eksperimen psikologi sosial pertama kali oleh Norman Triplett diawali dengan pertanyaan "Mengapa pengendara sepeda mengendarai sepeda dengan lebih cepat ketika bersama-sama pengendara yang lain ?" Pertanyaan penelitian juga bisa muncul dengan membaca hasil penelitian yang sudah ada, sehingga bisa memberikan inspirasi untuk melakukan penelitian selanjutnya.

2. Mencari dan mengumpulkan literatur

Literatur bisa digunakan oleh peneliti untuk mengkaji dan membahas pertanyaan penelitian atau ide original yang diajukan di awal. Literatur bisa diperoleh dengan menggunakan buku-buku teks psikologi sosial maupun hasil-hasil penelitian sebelumnya yang sudah dipublikasikan, dan bisa diakses melalui internet (elektronik jurnal). Dengan membaca artikelartikel penelitian terbukti sangat berharga dalam membantu peneliti untuk melacak berbagai informasi terkait pertanyaan penelitian.

3. Menyusun hipotesis dan teori

Hipotesis merupakan pernyataan secara eksplisit dugaan atau prediksi yang dapat diuji tentang berbagai keadaan yang bisa 
terjadi, berdasarkan hasil pengamatan, teori, atau temuan penelitian sebelumnya. Memformulasikan hipotesis ini penting sebagai tahap awal untuk merencanakan dan melakukan penelitian. Hal ini memungkinkan seorang peneliti untuk beralih dari akal sehat menuju metode ilmiah. Setelah pengembangan hipotesis dan pengumpulan data untuk menguji hipotesis, langkah selanjutnya yaitu menyusun teori. Teori merupakan serangkaian prinsip yang terorganisasi digunakan untuk menjelaskan berbagai fenomena yang telah diamati. Teori yang baik dan tepat mampu : mencakup semua informasi yang relevan dalam penelitian, mengarahkan pada hipotesis baru, menstimulasi penelitian lebih lanjut, dan memunculkan pemahaman yang lebih baik.

4. Penelitian dasar dan terapan

Penelitian psikologi sosial tidak hanya bertujuan untuk menguji sebuah teori, yang penelitiannya disebut juga dengan penelitian dasar. Penelitian dasar berusaha untuk meningkatkan pemahaman tentang perilaku manusia yang sering dirancang untuk menguji sebuah hipotesis spesifik dari sebuah teori yang spesifik. Penelitian terapan memiliki tujuan yang berbeda, yaitu menggunakan teori atau metode penelitian psikologi sosial untuk meningkatkan pemahaman kita tentang berbagai peristiwa sosial secara alami dan untuk memberikan kontribusi dalam penyelesaian persoalanpersoalan sosial.

B. Menyempurnakan Ide Penelitian (Mendefinisikan dan Mengukur Variabel Psikologi Sosial)

Tidak menjadi persoalan metode penelitian apapun yang direncanakan peneliti untuk menguji hipotesis yang diajukan, peneliti harus memutuskan bagaimana mereka akan 
mendefinisikan dan mengukur variable-variabel yang diminati peneliti. Hal ini merupakan proses yang mudah untuk dilakukan. Misalnya, jika kita tertarik untuk mengkaji pengaruh harga diri (selfesteem) terhadap perilaku altruisme, maka pertama kali kita harus mendefinisikan harga diri dan perilaku altruistik. Berikut dipaparkan langkah-langkah yang dilakukan dalam tahapan ini :

\section{Variabel konseptual dan definisi operasional}

Saat pertama kali seorang peneliti membangun sebuah hipotesis, tipe variabel berbentuk abstrak, secara umum (general). Inilah yang disebut dengan variabel konseptual (conceptual variables). Agar bisa dilakukan pengujian hipotesis, peneliti harus mentransformasikan variabel konseptual tersebut menjadi variabel yang bisa diukur atau dimanipulasi dalam penelitian. Upaya yang dilakukan agar sebuah variabel konseptual dimanipulasi atau diukur dinamakan dengan definisi operasional variabel penelitian.

\section{Mengukur variabel}

Para ahli psikologi sosial mengukur variabel melalui banyak cara, namun secara garis besar dikelompokkan menjadi dua kategori, yaitu pelaporan diri (self-reports) dan pengamatan (observasi). Self-reports merupakan sebuah teknik pengukuran dalam psikologi sosial dimana partisipan penelitian secara tertutup menyampaikan pikiran, perasaan, keinginan, dan tingkah lakunya. Self-reports bisa terdiri dari pertanyaan individual atau serangkaian pertanyaan yang bersama-sama mengukur sebuah variabel konsep tunggal. Satu pengukuran self-reports yang terkenal yaitu Rosenberg Self-Esteem Scale, berisikan serangkaian pertanyaan yang mengukur harga diri (self-esteem) individu. Self-reports memberikan peneliti akses untuk mengukur keyakinan dan persepsi individu. Namun selfreports tidak selamanya akurat dan bisa menyesatkan. 
Self-reports bukan satu-satunya alat yang digunakan oleh para ahli psikologi sosial untuk mengukur variabel. Peneliti juga bisa mengukur variabel dengan teknik lain yaitu mengamati (observasi) perilaku individu. Penggunaan observasi terkadang mudah, namun di waktu lain observasi lebih rumit dan menuntut interrater reliability yang mapan. Interrater reliability merujuk pada level persetujuan di antara banyak pengamat (observer) pada perilaku yang sama. Hanya ketika pengamat yang berbeda setuju, data dapat dipercaya.

\section{Menguji Ide Penelitian (Desain Penelitian)}

Para ahli psikologi sosial menggunakan beberapa metode yang berbeda untuk menguji hipotesis penelitian dan teori.

\section{Desain Penelitian Deskriptif}

Salah satu cara yang jelas untuk menguji ide-ide tentang orangorang hanyalah merekam seberapa sering atau bagaimana biasanya orang berpikir, merasa, atau berperilaku dalam caracara tertentu. Tujuan dari penelitian deskriptif dalam psikologi sosial adalah untuk mendeskripsikan pikiran, perasaan, dan perilaku orang-orang dalam setting sosial. Misalnya, bagaimana perilaku supporter sepakbola ketika berada dalam kelompoknya ? Metode yang digunakan dalam penelitian deskriptif meliputi observasi (observational studies), mempelajari catatan peristiwa dan perilaku individu di masa lalu (archivel studies), dan survei (survey).

\section{a. Observational studies}

Secara sederhana perilaku orang lain bisa dipelajari dengan melakukan pengamatan (observasi) terhadap mereka, termasuk berbagai kajian dalam psikologi sosial bisa dilakukan dengan menggunakan observasi. Observasi yang dilakukan bukan seperti observasi informal sehari-hari, 
namun observasi ini dilengkapi dengan standar pengukuran yang akurat dan teliti.

\section{b. Archival studies}

Teknik kearsipan (archival studies) ini melibatkan data-data yang berbentuk dokumen atau catatan peristiwa dan perilaku individu di masa lalu, seperti sebuah artikel di surat kabar, catatan kesehatan, diari, statistik tindak kejahatan, dan sebagainya. Catatan atau dokumen ini dianalisis dalam upaya untuk mengkonfirmasikan sebuah hipotesis. Keuntungan utama dengan penggunaan teknik ini adalah peneliti mengamati perilaku orang lain, dimana kehadiran peneliti tidak mempengaruhi perilaku individu yang sedang diamati, karena individu tidak mengetahui jika mereka sedang diamati atau diselidiki. Pengukuran kearsipan ini sangat bermakna untuk menjelaskan tren budaya dan sejarah.

\section{c. Survey (survei)}

Dalam teknik ini peneliti meminta sejumlah besar partisipan untuk memberikan respon atau menjawab terhadap pertanyaan-pertanyaan tentang sikap, keyakinan, atau perilaku mereka. Para ahli psikologi sosial menggunakan teknik ini untuk mengukur sikap individu mengenai isu-isu sosial, seperti persepsi masyarakat tentang pelaksanaan pilkada, bagaimana reaksi pelanggan terhadap sebuah produk baru, dan lain-lain. Keuntungan dari teknik ini yaitu informasi dapat diperoleh dari ratusan bahkan ribuan orang dengan relatif mudah. Beberapa hal yang perlu diperhatikan dalam penggunaan survei agar hasilnya akurat, yaitu pertama, pengambilan sampel harus dilakukan dengan teknik sampling yang benar atau cermat, agar hasilnya bisa digeneralisasikan kepada populasi yang 
lebih besar dimana responden menjadi anggotanya. Kedua, perumusan pertanyaan harus secara hati-hati. Ketiga, seringkali partisipan tidak memberikan respon atau jawaban yang tepat. Hal ini disebabkan karena kemungkinan partisipan tidak ingat dengan perilakunya di masa lalu dan kecenderungan individu untuk menghadirkan dirinya sebaik mungkin sehingga mereka tidak mengungkapkan sesuatu tentang dirinya secara jujur atau apa adanya (Dayakisni \& Hudaniah, 2003).

\section{Desain Penelitian Korelasional (mencari hubungan)}

Sebagian besar hipotesis penelitian dalam psikologi sosial fokus pada hubungan antara beberapa variabel. Misalnya, apakah ada hubungan antara jenis kelamin dengan kesediaan untuk meminta bantuan dari orang lain ? Penelitian korelasional bertujuan untuk menyelidiki hubungan (asosiasi) di antara dua atau lebih variabel yang berbeda. Para peneliti psikologi sosial mencoba untuk menentukan apakah dan seberapa besar variabel-variabel yang berbeda berhubungan satu sama lain, melalui uji statistik. Hasil dari penelitian korelasional dapat menentukan apakah suatu variabel berkorelasi positif, negatif, atau tidak berkorelasi (Kassin, et. al., 2008).

Beberapa kelebihan atau keuntungan dari desain penelitian korelasional, yaitu pertama memungkinkan seorang peneliti untuk mengumpulkan lebih banyak informasi dan menguji lebih banyak hubungan dari berbagai variabel (hal ini tidak bisa dilakukan dalam penelitian yang menggunakan desain eksperimen). Kedua, memungkinkan bagi peneliti untuk meneliti permasalahan sosial yang tidak mungkin dilakukan 
dengan menggunakan intervensi (intervensi bisa dilakukan dalam penelitian eksperimen).

Kelemahan dari desain penelitian korelasional, bahwa adanya korelasi di antara dua variabel atau lebih tidak memiliki implikasi bahwa variabel-variabel tersebut berhubungan secara kausalitas (sebab akibat), karena masingmasing variabel yang dikorelasikan tersebut dapat menjadi penyebab maupun akibat dari variabel yang lain (kausalitas silang). Misalnya hasil penelitian yang menunjukkan bahwa terdapat korelasi positif antara menonton adegan kekerasan (agresi) di televisi dengan perilaku agresi pada anak. Hasil penelitian mengindikasikan bahwa menonton tayangan kekerasan menyebabkan perilaku agresi pada anak. Namun hal yang sebaliknya bisa saja terjadi bahwa anak yang agresif dalam kehidupan sehari-harinya suka menonton tayangan kekerasan di televisi. Menurut Baron dan Byrne (2003), ambiguitas ini disebabkan variabel A atau B tidak mempengaruhi secara langsung, dimungkinkan terdapat variabel lain yang mempengaruhi kedua variabel tersebut (third-variable problem atau permasalahan variabel ketiga).

\section{Desain Penelitian Eksperimen (mencari sebab dan akibat)}

Pada desain penelitian ini melibatkan pengubahan secara sistematis terhadap sebuah variabel dan mengukur secara hati-hati efek dari perubahan tersebut pada satu atau lebih variabel lain. Apabila perubahan sistematis pada satu variabel menghasilkan perubahan pada variabel lain, maka bisa disimpulkan bahwa memang terdapat hubungan sebab akibat di antara variabel-variabel tersebut. Artinya, perubahanperubahan pada satu variabel memang menyebabkan 
perubahan-perubahan pada variabel lain (Baron \& Byrne, 2003).

Desain penelitian eksperimen mensyaratkan sekurang-kurangnya dua kelompok untuk dibandingkan satu dengan yang lain, dimana satu kelompok menerima perlakuan tertentu (treatment) yang diberikan oleh peneliti, sedangkan kelompok lainnya tidak menerima treatment atau dalam beberapa kasus memperoleh bentuk treatment yang berbeda. Dalam penelitian eksperimen, peneliti menciptakan dua atau lebih kondisi yang berbeda secara jelas. Kemudian partisipan penelitian secara acak dimasukkan ke dalam salah satu dari kondisi yang berbeda itu kemudian respon mereka diukur. Misalnya, eksperimen tentang pengaruh tayangan atau film kekerasan di televisi terhadap perilaku agresi pada anak. Satu kelompok anak diajak menonton film beradegan kekerasan hingga beberapa kali tayangan dan kelompok anak lainnya menonton film tanpa adegan kekerasan. Jika hasilnya kelompok anak-anak yang menonton adegan kekerasan berperilaku lebih agresif dibandingkan kelompok yang tidak menonton tayangan kekerasan, dapat disimpulkan bahwa tayangan kekerasan dapat menyebabkan meningkatnya perilaku agresi pada anakanak.

Desain penelitian eksperimen memiliki beberapa karakteristik (Baron \& Byrne, 2003), yaitu pertama peneliti memiliki kontrol penuh terhadap prosedur eksperimen. Melalui manipulasi terhadap variabel yang menjadi fokus pengukurannya (variabel yang diduga menjadi penyebab), peneliti dapat mengendalikan munculnya perilaku yang menjadi akibat. Kedua, adanya random assignments, yaitu partisipan penelitian atau eksperimen secara acak (bisa dilakukan dengan cara melempar koin, melempar dadu, 
mengambil kartu secara acak, atau menggunakan program komputer) ditugaskan untuk berada pada kondisi manipulasi yang berbeda di dalam eksperimen, artinya masing-masing subjek memiliki kesempatan atau peluang yang sama untuk ditugaskan pada kelompok eksperimen (group treatment) maupun kelompok kontrol. Random assignment berarti bahwa partisipan eksperimen tidak ditugaskan karena pertimbangan karakteristik personal tertentu. Sebelum pelaksanaan eksperimen, kedua kelompok atau lebih memiliki karakteristik yang sama sehingga ketika eksperimen dilakukan diperoleh efek yang benar-benar disebabkan oleh kondisi perlakuan yang diberikan peneliti.

Penelitian dengan desain eksperimen dalam psikologi sosial bisa dilakukan dengan eksperimen laboratorium (laboratory experiments) maupun eksperimen lapangan (field experiments). Eksperimen laboratorium dilakukan dalam suatu lingkungan yang terkontrol dimana peneliti melakukan kontrol secara rinci dan konstan terhadap lingkungan maupun partisipan penelitian. Setting laboratorium memungkinkan partisipan tahu bahwa dirinya sedang diamati sehingga perilaku yang dimunculkan bukan perilaku yang sebenarnya. Sedangkan eksperimen lapangan mempelajari perilaku dalam situasi yang sebenarnya atau alami, seperti di jalan raya, taman, dalam bis, di kelas, dan sebagainya. Kelebihannya partisipan penelitian berperilaku secara alami dalam situasi alami dibandingkan jika di dalam laboratorium dimana mereka tahu jika sedang diamati. Kelemahannya yaitu eksperimenter seringkali tidak bisa mengendalikan partisipan dalam berbagai kondisi sehingga beberapa peristiwa dan kondisi mengaburkan pengaruh variabel yang diselidiki. 


\section{Meta-Analysis (mengkombinasikan hasil berbagai penelitian)}

Upaya lain yang bisa dilakukan untuk menguji hipotesis dalam psikologi sosial adalah dengan menggunakan serangkaian prosedur statistik untuk menjelaskan, dengan cara mensintesiskan hasil penelitian-penelitian yang relevan. Teknik inilah yang dinamakan dengan meta-analysis. Menurut Miller dan Cooper (1991), meta-analysis merupakan teknik statistik yang dilakukan oleh peneliti dengan cara mereview dan mensistesiskan temuan empiris secara sistematis (Kassin, et. al., 2008). Misalnya, hasil penelitian tentang efek alkohol terhadap perilaku agresi, terkadang bertentangan satu dengan yang lain. Kadang-kadang alkohol meningkatkan agresivitas, namun terkadang tidak. Dengan mengkombinasikan data dari berbagai penelitian yang relevan dengan hipotesis dan melakukan meta-analysis, seorang peneliti dapat menentukan apa efek alkohol secara khusus, seberapa kuat efek tersebut, dan bahkan dalam kondisi spesifik seperti apa kemungkinan efek tersebut bisa terjadi. Melalui teknik meta-analysis hasil beberapa penelitian yang telah dilakukan dengan tempat dan peneliti berbeda, membantu seorang ahli psikologi sosial untuk mengukur secara tepat seberapa kuat dan reliablel dari efek tertentu.

Langkah-langkah yang dilakukan dalam teknik metaanalysis sebagai berikut (Kassin, et. al., 2008) :

a. Menemukan sebanyak mungkin studi atau penelitian tentang topik yang sama atau relevan

b. Menggunakan metode statistik untuk mengumpulkan informasi dari studi yang ada dan memperkirakan besarnya temuan. Metode statistik juga digunakan untuk mengetes konsistensi (homogenitas) dari temuan berbagai penelitian. Jika hasil dari berbagai penelitian cukup konsisten, peneliti 
bisa lebih percaya terhadap temuan tersebut. Ketika hasil dari berbagai penelitian berbeda-beda, teknik metaanalysis bisa membantu peneliti untuk mencari faktor lain yang mungkin penting.

\section{Budaya dan Metode Penelitian}

Beberapa penelitian dalam psikologi sosial juga dilakukan dengan mengembangkan minat untuk mempelajari atau mengkaji perilaku sosial dari berbagai kultur atau budaya. Sebagai contoh, sebuah eksperimen yang dilakukan untuk menjelaskan reaksi pelajar dari negara-negara bagian utara dan Brazil terhadap sebuah cerita tentang seorang perempuan yang curang atau tidak kepada suaminya (Vandello \& Cohen, 2003, dalam Kassin, et. al., 2008). Keuntungan penelitian dengan pendekatan budaya adalah menyediakan tes yang lebih baik untuk validitas eksternal dari penelitian yang telah dilakukan dalam berbagai setting. Dengan memeriksa apakah hasil sebuah eksperimen digeneralisasikan untuk sebuah kultur yang sangat berbeda, para ahli psikologi sosial bisa memulai untuk menjawab pertanyaan-pertanyaan tentang keuniversalan atau kekhasan budaya dari penelitian mereka. Penting untuk dipahami bahwa saat ada sebuah temuan penelitian dari sebuah budaya atau kultur tidak bisa digeneralisasikan sepenuhnya pada budaya lainnya. Hal ini bukanlah berarti terjadi kegagalan untuk melakukan replikasi penelitian, namun bisa sebagai sebuah kesempatan untuk mempelajari tentang potensi menarik dan penting dalam perbedaan budaya, serta bagaimana dan mengapa perbedaan ini mempengaruhi permasalahan yang sedang dipelajari. 


\section{Etika Penelitian Psikologi Sosial}

Terlepas dimana penelitian dilakukan dan apa metode penelitian yang digunakan, sebuah penelitian harus mempertimbangkan etika. Dalam psikologi sosial, perhatian etika sering difokuskan pada penggunaan tipuan oleh peneliti. Beberapa studi dalam psikologi sosial yang menimbulkan pertentangan terkait etika (Brehm \& Kassin, 1996) sebagai berikut :

1. Penelitian Stanley Milgram tentang kepatuhan (obedience) yang menggunakan desain penelitian eksperimen untuk menjawab pertanyaan "Apakah orang-orang akan mematuhi perintah jika diminta meski harus menyakiti seseorang yang tidak bersalah?" Untuk menjawab pertanyaan ini, Milgram menempatkan partisipan penelitian dalam dalam situasi dimana seorang eksperimenter memerintahkan mereka untuk memberikan sengatan listrik yang mengejutkan kepada seseorang yang mereka pikir sebagai partisipan lainnya (kenyataannya orang lain tersebut merupakan konfederasi yang sebenarnya tidak menerima sengatan apapun). Banyak partisipan eksperimen yang mengalami kecemasan dan stres karena memperdebatkan apakah mereka seharusnya tidak mentaati eksperimenter atau melanjutkan untuk menyakiti orang lain.

2. Penelitian Zimbardo dengan desain eksperimen tentang simulasi tahanan (1973). Pada penelitiannya, para partisipan eksperimen diminta untuk memerankan tahanan dan penjaga tahanan (sipir penjara). Topik penelitian Zimbardo adalah untuk mengetahui seberapa besar pengaruh peran sosial terhadap perilaku. 
Para ahli psikologi umumnya sepakat bahwa kapanpun jika memungkinkan pelaksanaan penelitian semestinya tidak melibatkan penipuan. Namun kenyataannya, beberapa isu penting yang diteliti dalam psikologi sosial berkaitan erat dengan norma-norma, seperti altruism, agresi, prasangka. Sementara itu kebanyakan orang memiliki motivasi untuk berperilaku yang memberikan kesan secara sosial bisa diterima (sebagai orang yang altruistik, tidak agresif, tidak berprasangka), sehingga saat tahu bahwa dirinya sedang diamati atau diselidiki oleh peneliti, maka perilaku yang ditunjukkan kemungkinan bukan perilaku yang sebenarnya (Dayakisni dan Hudaniah, 2003). Oleh karena itu, seorang peneliti terkadang menggunakan teknik menipu atau mengelabui subjek agar dapat mempelajari bagaimana orang bertingkah laku yang sebenarnya (alami).

American Psychological Association (APA) pertama kali mengembangkan kode etik penelitian psikologi pada tahun 1972 dan merevisi pedoman etik tersebut ketika isu baru muncul (APA, 1992). Terdapat tiga isu etika penting dalam penelitian psikologi (Sears, et. al., 1985) sebagai berikut :

\section{Debriefing (menjelaskan semuanya)}

Debriefing berarti menjelaskan secara detil terkait tujuan dan prosedur penelitian. Setelah penelitian atau eksperimen berakhir, eksperimenter menjelaskan kepada partisipan tentang apa yang telah dilakukan, mengapa dilakukan, dan apa maksudnya. Partisipan harus diberi kesempatan untuk mengajukan pertanyaan dan mengekspresikan perasaannya. Terkadang peneliti mengirimkan informasi tertulis kepada subjek penelitian yang berisikan hasil penelitian setelah dilakukan analisis. 


\section{Informed consent}

Merupakan persetujuan dengan sepengetahuan subjek penelitian. Subjek penelitian harus setuju tanpa paksaan untuk ikut serta atau berpartisipasi dalam penelitian dan harus memahami apa yang akan dijalani. Persyaratan ini terkadang menimbulkan permasalahan bagi peneliti di bidang psikologi. Beberapa studi atau penelitian justru tidak harus memberi tahu subjek penelitian terkait tujuan penelitian yang sesungguhnya agar tidak muncul bias respon sehingga hasil penelitian tidak valid. Bahkan pada penelitian yang sederhana, subjek penelitian jarang diberi tahu hipotesis spesifik penelitian. Pandangan yang lebih moderat didukung oleh para ahli psikologi menyatakan bahwa penipuan tidak boleh digunakan jika memungkinkan dan boleh dipakai jika telah melalui pertimbangan terkait manfaat penelitian yang lebih besar dibandingkan efek kerugiannya. Partisipan penelitian tidak harus diberi tahu segalanya yang akan dilakukan dalam penelitian, namun yang utama mereka harus tahu bahwa sedang terlibat dalam penelitian dan setuju tanpa dipaksa.

\section{Minimal risk}

Resiko minimal (minimal risk) berarti bahwa kemungkinan resiko yang muncul saat berpartisipasi dalam penelitian tidak lebih besar dibandingkan yang dihadapi dalam kehidupan sehari-hari (meminimalkan resiko potensial). Beberapa jenis resiko yang mungkin ditimbulkan oleh penelitian psikologi sosial, pertama hak privasi individu. Peneliti yang melakukan penelitian dengan topik sensitif (seks, narkoba, perilaku yang dianggap menyimpang oleh lingkungan, religius) harus melindungi hak subjek dengan menyimpan informasi dan merahasiakannya. Kedua, 
terkait stres yang dialami subjek penelitian, seperti bosan, gelisah, ketakutan, bahkan kemungkinan mengancam harga diri subjek. Ketiga bahwa penelitian yang dilakukan tidak menimbulkan efek substansial pada subjek penelitian setelah selesai mengikuti penelitian.

Penelitian psikologi sosial memiliki tanggung jawab untuk memperlakukan subjek penelitian atau partisipan dengan baik dan beretika, jika diperlukan juga bisa memberikan penghargaan sepantasnya atas bantuan mereka dalam penelitian (Sears, et. al., 1985). 


\section{BAB 4}

\section{DIRI SOSIAL (SOCIAL SELF)}

\section{Capaian Pembelajaran Mata Kuliah :}

a. Aspek Sikap dan Tata Nilai :

(1) Bertakwa kepada Tuhan Yang Maha Esa dan mampu menunjukkan sikap religious

(2) Berkontribusi dalam peningkatan mutu kehidupan bermasyarakat, berbangsa, bernegara, dan kemajuan peradaban berdasarkan Pancasila

(3) Menghargai keanekaragaman budaya, pandangan, agama dan kepercayaan serta pendapat atau temuan orisinal orang lain

b. Aspek Ketrampilan Umum :

(1) Menguasai konsep teoritis hubungan manusia dengan lingkungan sosialnya

(2) Menguasai konsep teoritik komunikasi antar pribadi dan komunikasi massa

c. Aspek Ketrampilan Khusus :

Mampu menerapkan pemikiran logis, kritis, sistematis, dan inovatif dalam konteks pengembangan atau implementasi ilmu pengetahuan dan teknologi yang memperhatikan dan menerapkan nilai humaniora

d. Aspek Penguasaan Pengetahuan :

Mampu memahami dan menjelaskan peranan Psikologi Sosial dalam proses interaksi sosial, serta menerapkan dalam menyelesaikan permasalahan sosial. 
Self (diri) merupakan topik yang dalam beberapa tahun terakhir telah menarik minat di antara para ahli psikologi sosial (Leary \& Tangney, 2003; Tesser et al., 2005; Vohs \& Finkel, 2006, dalam Kassin, et. al., 2008). Baron dan Byrne (2003) menyatakan bahwa bagian dari siapakah diri kita dan bagaimana kita berpikir tentang diri kita sendiri ditentukan oleh identitas kolektif yang disebut sebagai diri social (social self). Diri sosial terdiri dari dua komponen, yaitu berasal dari hubungan interpersonal dan dari keanggotaan seseorang pada kelompoknya.

\section{A. Konsep Diri (Self-Concept)}

Konsep diri (self-concept) merupakan komponen kognitif mengenai diri (self) seseorang, yaitu merujuk pada keseluruhan keyakinan individu tentang dirinya (Kassin, et. al., 2008). Menurut Hazel Markus (1977), konsep diri terdiri dari komponen kognitif (self-schemas), yaitu keyakinan individu tentang dirinya sendiri yang memandu pemrosesan informasi yang relevan dengan dirinya (Kassin, et. al., 2008). Konsep diri merupakan keyakinan yang dimiliki individu tentang atribut yang dimilikinya (Brehm \& Kassin, 1996).

Kenrick et al. (2002) menyatakan bahwa konsep diri merupakan sebuah representasi mental yang menggambarkan pandangan dan keyakinan individu tentang dirinya sendiri. Konsep diri merupakan keyakinan (belief) individu tentang atribut yang melekat dalam diri sendiri, dimana keyakinan tersebut muncul setelah individu menyadari tentang dirinya dengan sifat-sifat yang melekat, baik melalui pengalaman pribadi, interaksi sosial, maupun dari proses perenungan (Suryanto, et. al., 2012). 
Sumber-sumber yang membentuk konsep diri atau pengetahuan tentang diri (self) menurut Kenrick, et. al. (2002) sebagai berikut :

\section{Proses persepsi diri (self perception process)}

Individu mempersepsi dirinya dengan mengamati perilakunya sendiri dalam keseharian.

2. Penaksiran yang direfleksikan (reflected appraisals process)

Individu melakukan penaksiran tentang dirinya sendiri dengan merefleksikan atau bercermin dari apa yang dikatakan orang lain tentang tentang dirinya. Evaluasi tentang diri individu dipengaruhi oleh apa yang diucapkan orang lain tentang individu. Misalnya, ketika orang tua mengatakan kepada anaknya bahwa dia pandai, anak akan berpikir seperti apa yang dikatakan orang tua tersebut.

\section{Perbandingan sosial (social comparison)}

Menurut Festinger (1954), individu memperoleh pengetahuan tentang dirinya dengan cara membandingkan dirinya (kemampuan, sikap, keyakinan, tingkah laku) dengan orang lain. Misalnya, ketika seseorang membandingkan bahwa nilainya lebih baik dari temanteman lainnya, individu akan mengetahui tentang kemampuannya.

\section{Memori autobiografi (autobiographical memories)}

Filosof James Mill berpendapat bahwa fenomena self dan memori bagaikan dua sisi mata uang. Tanpa memori autobiografi (ingatan tentang urutan kejadian yang telah kita alami), kita tidak akan memiliki konsep diri yang koheren (Kassin, Fein, \& Markus, 2008). Seseorang bisa mengenali dirinya dari ingatan tentang pengalaman penting selama hidupnya. Ketika orang-orang diminta 
untuk mengingat kembali pengalamannya, mereka biasanya melaporkan lebih banyak peristiwa yang baru saja terjadi daripada masa lalu yang jauh ke belakang.

\section{Pengaruh budaya}

Konsep diri juga dipengaruhi oleh faktor budaya. Budaya individualisme dan kolektivisme mempengaruhi cara pandang seseorang terhadap konsep diri dan identitas diri. Menurut Hazel Markus dan Shinobu Kitayama (1991), sebagian besar bangsa Amerika Utara dan Eropa memiliki independent view tentang self, yang beranggapan bahwa self merupakan sebuah entitas yang berbeda, otonom (mandiri), dan unik. Keberhasilan seseorang dipandang karena usaha sendiri. Namun pada banyak negara di Asia, Afrika, dan Amerika Latin, orang-orang memegang interdependent view tentang diri (self), yang beranggapan bahwa self merupakan bagian dari sebuah jaringan sosial yang lebih besar yang mencakup keluarga, rekan kerja, dan orang-orang lain yang terhubung secara sosial. Pada pandangan ini, orang-orang tidak menganggap keberhasilannya karena usaha sendiri, melainkan karena kerja sama dalam kelompok. Jadi, orientasi budaya seseorang mempengaruhi caranya mempersepsi, mengevaluasi, dan mempresentasikan dirinya dalam relasi dengan orang lain.

\section{Perbandingan Sosial (Social Comparison)}

Perbandingan sosial merupakan salah satu cara yang dilakukan oleh seseorang untuk memperoleh pengetahuan tentang dirinya sendiri, dengan cara membandingkan dirinya dengan orang lain. Leon Festinger sebagai pencetus teori ini menyatakan bahwa ketika orang merasa tidak yakin tentang 
kemampuan atau pendapatnya, dan ketika tidak tersedia informasi yang objektif, maka mereka mengevaluasi dirinya sendiri melalui perbandingan dengan orang yang sama (lateral comparison), seperti laki-laki dengan laki-laki, perempuan dengan perempuan, miskin dengan miskin, kaya dengan kaya, dan sebagainya. Individu juga dapat melakukan perbandingan dengan orang lain yang lebih baik (upward social comparison) maupun yang lebih tidak baik (downward social comparison) dari dirinya. Perbandingan sosial yang dilakukan seseorang, bisa berdampak pada meningkatnya atau bahkan menurunnya harga diri. Dengan melakukan perbandingan sosial terhadap orang yang lebih buruk dari dirinya (downward social comparisons), bisa membantu seseorang untuk mengetahui bahwa kehidupan orang lain bisa lebih buruk dari dirinya. Sebaliknya, melakukan perbandingan dengan orang yang lebih baik dari dirinya (upward social comparisons), bisa menurunkan harga diri seseorang.

Seperti yang disampaikan oleh Festinger, perbandingan sosial dilakukan saat evaluasi yang objektif tentang diri sendiri tidak tersedia. Kenyataannya, beberapa studi yang terbaru menyatakan bahwa orang menilai dirinya dalam relasinya dengan orang lain bahkan meskipun standar objektif tersedia. Motif dasar melakukan perbandingan dengan orang lain karena ingin memperoleh gambaran yang positif tentang diri sendiri, bukan karena ingin memperoleh gambaran yang akurat atau objektif tentang diri sendiri (Baumeister, dalam Sarwono \& Meinarno, 2009).

Dalam rangka untuk memperoleh gambaran diri yang positif, orang akan memilih untuk membandingkan dirinya dengan orang lain yang sama (lateral comparison) atau yang lebih tidak baik dari dirinya. Orang akan menghindari 
melakukan perbandingan sosial dengan orang lain yang lebih baik dari dirinya untuk mempertahankan harga diri (Tesser dalam Sarwono \& Meinarno, 2002).

\section{B. Harga Diri (Self-Esteem)}

Harga diri (self-esteem) merupakan komponen afektif atau evaluativf dari self (Delamater \& Myers, 2011). Harga diri merujuk pada penilaian (evaluasi) kita secara positif maupun negatif terhadap diri kita sendiri (Coopersmith, 1967, dalam Kassin, et. al., 2008). Beberapa individu memiliki harga diri yang lebih tinggi dibandingkan lainnya. Penting untuk diingat, bagaimanapun juga, meskipun beberapa dari kita memiliki harga diri yang lebih tinggi dibandingkan dengan yang lain, sebuah perasaan harga diri bukanlah sebuah trait tunggal yang menetap secara permanen, sehingga harga diri pun bisa berubah. Sebaliknya, harga diri menjadi bagian dari pikiran yang berfluktuasi dalam respon terhadap kesuksesan, kegagalan, keberuntungan yang naik turun, relasi sosial, dan pengalaman hidup lainnya (Heatherton \& Polivy, 1991, dalam Kassin, et. al., 2008).

Sumber-sumber pembentukan harga diri seseorang menurut Delamater dan Myers (2011) sebagai berikut :

1. Pengalaman dalam keluarga.

Interaksi antara orang tua dan anak merupakan faktor penting bagi perkembangan harga diri. Coopersmith (1967) menyimpulkan bahwa terdapat empat perilaku orang tua yang mampu meningkatkan harga diri : (a) menunjukkan penerimaan, afeksi, minat, dan keterlibatan pada kegiatan anak; (b) menetapkan batasan-batasan perilaku anak secara jelas dan konsisten; (c) memberikan kebebasan dalam batas dan menghargai inisiatif; (d) menerapkan 
disiplin yang tidak memaksa (menghindari pemberian hakhak istimewa dan hukuman fisik, lebih pada mendiskusikan alasan)

2. Umpan balik terhadap performance seseorang (terkait kesuksesan atau kegagalan)

3. Perasaan seseorang tentang kemampuan (kompetensi) dan kekuasaan (power) untuk mengendalikan berbagai kejadian yang dialami

4. Perbandingan sosial (social comparison)

Saat harga diri seseorang dipertaruhkan, individu sering mendapatkan keuntungan dengan melakukan perbandingan sosial ke bawah (downward social comparisons) dengan orang lain yang kurang sukses, kurang bahagia, atau kurang beruntung (Kassin, et. al., 2008). Dengan melakukan hal ini, harga diri seseorang akan lebih baik atau meningkat. Apakah orang melakukan perbandingan ke bawah (downward social comparisons) maupun perbandingan ke atas (upward social comparisons), keduanya mampu memiliki implikasi yang mencolok untuk masalah yang terkait dengan kesehatan.

Pada umumnya, orang menginginkan harga diri yang positif, sehingga hal ini mendorong munculnya above-average effect, yaitu kecenderungan orang menilai dirinya di atas ratarata pada berbagai aspek diri yang dianggap positif secara sosial (Baron \& Byrne, 2003).

\section{Kesadaran Diri (Self-Awareness)}

Jika Anda secara cermat melihat ulang rutinitas sehari-hari seperti kuliah, bekerja, berinteraksi social, dan makan bersama, mungkin Anda akan terkejut betapa sedikit waktu yang Anda luangkan untuk berpikir tentang diri Anda 
sendiri. Saat kita makan bersama teman, membaca buku, kuliah, kerja, atau terlibat dalam sebuah pembicaraan, perhatian kita selalu tertuju langsung pada objek-objek tersebut, orang-orang, dan berbagai kejadian di sekitar kita. Namun apa yang terjadi saat kita berdiri di depan cermin, melihat foto diri kita sendiri, atau menyaksikan diri sendiri pada rekaman video ? Saat inilah kita memasuki sebuah bagian dari kesadaran diri (self-awareness), yaitu kita meletakkan diri kita sebagai objek atau pusat dari perhatian kita dan fokus pada penampilan, tindakan, dan pikiran kita sendiri.

Robert Wicklund dan koleganya sebagai pencetus teori kesadaran diri, mengemukakan bahwa orang-orang tidak selalu fokus pada dirinya sendiri, namun pada situasi tertentu memaksa mereka untuk melihat ke dalam diri mereka sendiri dan menjadi objek dari perhatiannya, seperti saat kita berbicara dengan diri kita sendiri, berdiri di depan cermin, melihat diri kita di videotape. Saat inilah kita memasuki kesadaran diri yang menyebabkan kita secara alami atau otomatis mengevaluasi atau membandingkan perilaku kita berdasarkan beberapa standar. Perbandingan inilah yang seringkali menghasilkan sebuah diskrepansi negatif (negative discrepancy) yang tidak menyenangkan dan untuk sementara menurunkan harga diri kita, sehingga kita menemukan bahwa diri kita jauh dari gambaran tentang diri ideal. Pada umumnya, orang-orang yang lebih terserap dirinya atau lebih memusatkan pada dirinya sendiri pada saat berada dalam pengalaman kesadaran diri, menimbulkan suasana hati yang negatif (bad mood) atau bahkan depresi, mengalami kecemasan, penyalahgunaan alkohol, dan mengalami gangguan-gangguan klinis lainnya (Kassin, et. al., 2008). 
Bagaimana solusinya jika pengalaman kesadaran diri menghasilkan perasaan yang tidak menyenangkan ? Teori kesadaran diri mengemukakan dua cara dasar untuk mengurangi diskrepansi tersebut, yaitu : (1) "shape-up", berperilaku dalam cara-cara yang bisa mengurangi diskrepansi diri, atau (2) "ship out", dengan melakukan penarikan diri (withdrawing) dari kesadaran diri. Menurut Charles Carver dan Michael Scheier (1981), solusi yang dipilih bergantung pada apakah orang berpikir mereka dapat mengurangi diskrepansi diri mereka dan apakah mereka senang dengan kemajuan yang mereka buat saat mereka mencoba (Duval, et. al., 1992 dalam Kassin, et. al., 2008). Jika begitu, mereka cenderung menyesuaikan perilaku mereka terhadap standar pribadi atau masyarakat, jika tidak, mereka menghilangkan, mencari gangguan, dan menjauhkan perhatian dari diri.

Menurut Buss, 1980 (dalam Kassin, et. al., 2008), berdasarkan hasil penelitian ditemukan terdapat perbedaan antara kesadaran diri pribadi (private self-consciousness) dan kesadaran diri publik (public self-consciousness). Kesadaran diri pribadi adalah kecenderungan untuk melakukan introspeksi tentang pikiran dan perasaan kita, sedangkan kesadaran diri public merupakan kecenderungan untuk fokus pada image atau citra publik kita yang terlihat dari luar (nampak oleh orang lain).

Kesadaran diri pribadi dan kesadaran diri publik merupakan sifat (trait) yang berbeda. Orang-orang yang memiliki skor tinggi pada sebuah tes kesadaran diri pribadi akan mengisi kalimat dengan tidak lengkap dengan kata ganti orang pertama (first person pronouns). Mereka juga membuat pernyataan deskripsi diri dan mengenali lebih cepat kata-kata yang relevan dengan diri sendiri daripada kata-kata lain. Sebaliknya, orang-orang dengan skor tinggi pada pengukuran 
kesadaran diri publik, mereka sensitif terhadap cara-cara dimana mereka dilihat dari perspektif luar diri (Kassin, et. al., 2008).

Perbedaan antara private dan public self-awareness memiliki implikasi terhadap upaya untuk mengurangi diskrepansi diri. Menurut Higgins, 1989 (dalam Kassin, et. al., 2008), orang akan termotivasi untuk menemukan standar diri mereka sendiri atau standar yang dibentuk oleh significant others untuk mereka. Jika Anda kesadaran dirinya pribadi, Anda akan mendengarkan suara dari dalam diri dan mencoba untuk mengurangi diskrepansi dengan standar yang Anda miliki. Sedangkan jika Anda kesadaran dirinya publik, Anda akan mencoba untuk menyesuaikan perilaku Anda dengan normanorma yang secara social bisa diterima.

\section{Presentasi Diri (Self-Presentation)}

Dalam berinteraksi dengan orang lain, kebanyakan orang ingin menghadirkan image tertentu sesuai dengan yang diinginkan kepada orang lain. Individu seringkali memfokuskan pada kesan yang ingin ditampilkan melalui perilaku publik (Kassin, et. al., 2008). Menurut Erving Goffman (1959) seorang ahli sosiologi, kehidupan merupakan panggung teater dan masing-masing orang bertindak memerankan peran-peran tertentu sesuai naskah (script). Yang terpenting, lanjut Goffman, masing-masing orang mengasumsikan wajah tertentu, atau identitas sosial, dimana orang lain bersedia membantu untuk mempertahankannya. Terinspirasi dari teori Goffman tersebut, para ahli psikologi mempelajari tentang presentasi diri (self-presentation).

Presentasi diri (self-presentation) dikenal juga sebagai manajemen kesan atau impression management 
(Kenrick et. al., 2002). Presentasi diri merujuk pada proses dimana individu melakukan pengendalian atau pengelolaan kesan dimana orang lain akan membentuk kesan tentang mereka dalam interaksi sosial (Delamater \& Myers, 2011). Menurut Kassin, et. al., (2008), presentasi diri merupakan sebuah proses dimana kita berusaha untuk membentuk apa yang dipikirkan orang lain tentang kita dan apa yang kita pikirkan tentang diri kita sendiri. Individu yang terlibat mungkin menyadari atau tidak proses ini.

Dalam presentasi diri, fokusnya adalah untuk menetapkan sebuah image publik tentang diri kita sendiri yang konsisten dengan apa yang diinginkan atau diharapkan oleh orang lain tentang diri kita. Kita bisa melakukan hal ini, misalnya dengan mengklaim bahwa kita memiliki beberapa atribut yang mereka hargai, meskipun secara nyata kita tidak memiliki atribut tersebut. Orang-orang menggunakan teknik presentasi diri secara umum bertujuan agar mereka dilihat dan dinilai secara positif oleh orang lain, sehingga memperoleh penghargaan (reward) dari orang lain, seperti ingin disukai, untuk mempengaruhi orang lain, memperoleh posisi, mempertahankan status, dan sebagainya (Delamater \& Myers, 2011). Ketika seseorang menggunakan teknik presentasi diri untuk memanipulasi kesan orang lain tentang dirinya, bisa dikatakan dia menggunakan teknik pengelolaan kesan (tactical impression management). Bisa dijelaskan bahwa sebagai bagian dari impression management, maka individu melakukan presentasi diri dengan berbagai macam tujuan sesuai dengan yang diinginkan.

Argyle mengemukakan bahwa terdapat tiga motivasi primer dalam impression management, yaitu untuk memperoleh imbalan materi atau sosial (agar disukai, 
dihormati, dipuji, dan sebagainya), untuk mempertahankan atau meningkatkan harga diri, dan untuk mempermudah pengembangan identitas diri (Dayakisni \& Hudaniah, 2003). Motivasi untuk melakukan pengelolaan kesan biasanya sering terjadi dalam situasi yang melibatkan tujuan penting (persahabatan, persetujuan, imbalan materi) dimana individu yang melakukannya merasa kurang puas dengan image yang diproyeksikan saat ini. Selain itu, motivasi untuk mengelola kesan juga lebih kuat saat seseorang merasa tergantung pada seseorang yang berkuasa dimana orang tersebut mengendalikan sumber-sumber penting bagi dirinya.

Kesuksesan dalam presentasi diri ditentukan oleh dua hal berikut (Delamater \& Myers, 2011) :

1. Upaya untuk menetapkan definisi situasi

Agar interaksi berjalan dengan sukses, pihak-pihak yang terlibat di dalamnya harus berbagi pemahaman tentang realitas sosial mereka. Sesuai dengan pandangan teori interaksi simbolik (symbolic interaction theory) yang mengatakan bahwa agar interaksi sosial berjalan lancar maka orang-orang yang terlibat di dalamnya harus bersama-sama berbagi definisi sebuah situasi (kesepakatan tentang siapa mereka, apa tujuan mereka, perilaku seperti apa yang layak, dan apa artinya perilaku mereka). Untuk membentuk definisi situasi ini, orang-orang harus sepakat menjawab pertanyaan tentang : (a) apa tipe kegiatan sosial terdekat (pernikahan, reuni, interview pekerjaan, dan lainlain), dan apa kerangka (frame) interaksi ? (b) Identitas seperti apa yang diinginkan oleh partisipan dalam interaksi tersebut?

2. Upaya untuk mengungkapkan informasi tentang diri (self) yang konsisten dengan identitas yang diklaim (self- 
disclosure). Agar kita bisa mengetahui lebih banyak tentang orang lain dengan lebih baik maka kita mengungkapkan tentang diri kita sendiri secara lebih detil dan akrab.

Goffman mengajukan syarat-syarat yang harus dipenuhi apabila seseorang ingin melakukan pengeloaan kesan (impression management) secara baik (Dayakisni \& Hudaniah, 2003), sebagai berikut :

1. Penampilan muka (proper front), yaitu perilaku tertentu yang diekspresikan secara khusus oleh aktor agar orang lain mengetahui dengan jelas perannya.

2. Keterlibatan secara penuh dalam peran, sehingga membantu aktor untuk sungguh-sungguh meyakini perannya dan bisa menghayati perannya secara total.

3. Mewujudkan idealisasi harapan orang lain tentang peran aktor

4. Menjaga atau memelihara jarak sosial (mystification) antara aktor dan orang lain, agar tetap bisa menyadari perannya dan tidak hilang dalam proses tersebut.

Delamater dan Myers (2011) mengemukakan beberapa strategi presentasi diri, sebagai berikut :

1. Managing appearance (mengelola penampilan). Appearance merujuk pada segala sesuatu pada seseorang dimana orang lain bisa melihatnya, seperti pakaian, cara berdandan, kebiasaan yang terlihat (merokok, mengunyah permen karet), komunikasi verbal (dialek, kosakata), dan komunikasi nonverbal. Melalui appearance yang kita hadirkan, kita menunjukkan kepada orang-orang seperti apa kita dan aksi apa yang ingin kita lakukan. 
2. Ingratiation (mengambil muka atau menjilat), merupakan perilaku yang dimotivasi oleh keinginan untuk disukai orang lain.

3. Self-promotion (promosi diri), merupakan tindakan yang dimotivasi oleh keinginan untuk dianggap maju dan disegani karena kemampuan atau kompetensinya.

4. Aligning actions, merupakan upaya individu untuk mendefinisikan perilakunya yang nampaknya diragukan karena bertentangan dengan norma. Terdapat dua tipe penting dari aligning actions, yaitu disclaimers (menyangkal) dan accounts (alasan-alasan). Disclaimers merupakan pernyataan secara verbal yang bertujuan untuk menyangkal implikasi negatif dari tindakan yang akan datang dengan mendefiniskan tindakan ini yang dianggap tidak relevan dengan identitas sosial yang dimiliki seseorang. Dengan melakukan disclaimers, meskipun tindakan yang akan datang umumnya menghasilkan identitas negatif, tindakan tersebut merupakan kasus yang luar biasa. Misalnya "Saya tahu saya akan melanggar peraturan, tetapi .........." Selain disclaimers, bisa juga menggunakan teknik accounts (alasan-alasan), yaitu penjelasan-penjelasan yang ditawarkan orang-orang untuk mengurangi tanggung jawab setelah menampilkan tindakan yang dapat mengancam identitas sosialnya. Terdapat dua tipe utama dari accounts, yaitu excuses (meminta ma'af), adalah mengurangi atau menolak tanggung jawab dan justification (pembenaran) yaitu mengakui tanggung jawab untuk perilaku yang tidak layak namun juga berusaha untuk mendefinisikan perilaku itu sebagaimana sesuai dalam situasi tersebut. Contoh 
justification "Saya memang memukulnya, tapi dia memukul saya terlebih dulu."

5. Intimidation (mengancam atau menakut-nakuti). Strategi ini digunakan untuk menimbulkan rasa takut, dan sebagai upaya untuk memperoleh kekuasaan dengan cara meyakinkan orang lain bahwa dirinya orang yang berbahaya (Dayakisni \& Hudaniah, 2003).

6. Supplification (permohonan), yaitu meyakinkan seorang target bahwa kita membutuhkan dan layak memperoleh pertolongan atau simpati.

7. Altercasting, merupakan taktik presentasi diri untuk memaksakan peran dan identitas kepada orang lain. Melalui strategi ini, kita menempatkan orang lain dalam identitas situasi dan peran yang menguntungkan kita. Secara umum, altercasting melibatkan perlakuan terhadap orang lain seolah-olah mereka telah memiliki identitas dan peran yang ingin kita paksakan pada mereka. Misalnya guru mengatakan kepada muridnya "Saya tahu kamu bisa melakukan yang lebih baik dari itu." Ucapan ini menekan murid untuk menghayati sebuah identitas atau kemampuan yang dipaksakan.

8. Exemplification (pemberian teladan), yaitu memproyeksikan pada kejujuran dan moralitas, dengan mempresentasikan sebagai orang yang jujur, disiplin, dermawan, baik hati. Terkadang perilaku yang ditunjukkan memang mencerminkan keadaan yang sebenarnya, namun seringkali pengguna strategi ini berusaha memanipulasi dan tidak tulus dalam melakukannya (Dayakisni dan Hudaniah, 2003).

9. Self-handicapping, saat menghadapi kegagalan seringkali orang-orang beralasan bahwa kegagalan tersebut karena 
terdapat hambatan yang memang tidak bisa diatasi, bukan karena kelemahan mereka (Taylor, et. al., 2009). Misalnya, mahasiswa yang begadang semalaman sebelum ujian keesokan harinya, mengaitkan nilai yang buruk karena keletihan, bukan karena kemampuannya atau kemalasannya dalam belajar.

\section{Perbedaan Individu Dalam Self-Monitoring}

Meskipun presentasi diri merupakan cara yang dilakukan oleh kebanyakan orang, namun sangat berbeda antar individu. Beberapa orang umumnya sadar dengan image publik mereka dibandingkan orang lain. Selain itu, beberapa orang lainnya lebih menyukai menggunakan strategi presentasi diri, sementara orang lainnya terlihat lebih suka menggunakan selfverification (keinginan agar orang lain mempersepsi diri kita sebagaimana kita benar-benar mempersepsi diri kita sendiri).

Menurut Mark Snyder (1987), perbedaan tersebut disebabkan oleh sebuah sifat (trait) kepribadian yang disebut dengan monitoring diri (self-monitoring). Self-monitoring merupakan kecenderungan untuk mengubah perilaku sendiri untuk memenuhi atau menyesuaikan tuntutan situasi sosial (Kassin, et. al., 2008). Atau menurut Worchel, et. al. (2000), selfmonitoring adalah menyesuaikan perilaku terhadap normanorma situasional dan harapan-harapan orang lain. Dalam proses presentasi diri, terdapat orang yang memiliki selfmonitoring tinggi dan ada pula yang rendah. Individu dengan self-monitoring tinggi memiliki gambaran tentang penampilan dirinya, peka terhadap strategi presentasi diri, fokus pada apa yang layak secara sosial, menaruh perhatian pada bagaimana orang berperilaku dalam setting sosial. Sedangkan orang dengan self-monitoring rendah, kurang perhatian terhadap 
kesopanan atau kelayakan perilaku mereka, lebih menaruh perhatian pada perasaan sendiri, kurang responsif terhadap informasi tentang presentasi dirinya.

\section{E. Pengungkapan Diri (Self-Disclosure)}

Saat pertama kali kita bertemu dengan seseorang, seringkali kita berbicara tentang topik-topik yang dangkal dan aman, hanya sedikit informasi yang kita ungkapkan tentang diri kita sendiri. Bagaimanapun juga, pada akhirnya kita ingin mengetahui tentang orang lain dengan lebih baik, kita mengungkapkan lebih banyak dan akrab tentang diri kita sendiri secara mendetail, seperti informasi tentang keinginan, sikap, pengalaman, aspirasi, dan ketakutan (Archer, 1980, dalam Delamater \& Myers, 2011). Proses dimana kita mengungkapkan aspek-aspek pribadi dari perasaan dan perilaku kita kepada orang lain, dinamakan dengan pengungkapan diri (self-disclosure). Pengungkapan diri merupakan kegiatan berbagi perasaan dan informasi secara akrab dengan orang lain (Morton, dalam Sears, et. al., 2008).

Dalam self-disclosure berlaku norma resiprok atau timbal balik (norm of reciprocity). Terdapat sebuah norma sosial yang berlaku bahwa seseorang selayaknya merespon keterbukaan orang lain dengan keterbukaan pada tingkat keakraban yang setara (Kassin, et. al., 2008). Artinya, jika seseorang menceritakan sesuatu yang bersifat pribadi pada kita, kita akan cenderung memberikan reaksi yang sepadan. Pada umumnya kita mengharapkan orang lain memperlakukan diri kita sama seperti kita memperlakukan mereka. Namun, jika seseorang mengungkapkan informasi pribadi yang lebih detil atau akrab daripada yang kita lakukan, akan membuat kita merasa terancam dan kita cenderung lebih senang mengakhiri 
interaksi yang seperti ini. Sebaliknya, jika kita yang mengungkapkan terlalu akrab dibandingkan orang lain, kita akan merasa bodoh dan tidak aman (Sears, et. al., 2008).

Menurut Derlega dan Grzelak (dalam Sears, et. al., 2008), pengungkapan diri memiliki lima fungsi berikut ini :

1. Ekspresi (expression)

Pengungkapan diri memberikan kesempatan kepada individu untuk mengekspresikan perasaan kepada individu lain.

2. Penjernihan diri (self-clarification)

Denga melakukan pengungkapan diri tentang perasaan dan permasalahan yang sedang kita hadapi, kita bisa memperoleh penjelasan dan pemahaman orang lain terhadap permasalahan kita sehingga pikiran kita akan lebih jernih dan bisa melihat permasalahan dengan lebih baik

3. Keabsahan sosial (social validation)

Setelah kita menceritakan permasalahan yang sedang kita hadapi, pendengar akan memberikan tanggapan terkait permasalahan tersebut, bisa berupa dukungan atau sebaliknya.

4. Kendali sosial (social control)

Individu dapat mengemukakan atau menyembunyikan informasi tentang dirinya untuk kontrol social, misalnya seseorang akan menceritakan sesuatu hal yang dapat menimbulkan kesan baik tentang dirinya.

5. Perkembangan hubungan (relationship development)

Saling berbagi perasaan dan informasi tentang diri kita kepada orang lain disertai rasa saling percaya, menjadi jalan agar hubungan semakin akrab. 
Dalam proses hubungan interpersonal, terdapat tingkatan-tingkatan yang berbeda dalam pengungkapan diri. Menurut Powell (dalam Dayakisni \& Hudaniah, 2003), tingkatan-tingkatan pengungkapan diri dalam komunikasi sebagai berikut :

1. Basa-basi

Merupakan tingkatan pengungkapan diri yang paling dangkal, masing-masing individu berkomunikasi secara basa-basi, sekedar menciptakan kesopanan.

2. Membicarakan orang lain

Masing-masing individu mengungkapkan tentang orang lain atau hal-hal di luar dirinya, belum terjadi pengungkapan diri dari individu sendiri.

3. Menyatakan gagasan atau pendapat

Masing-masing individu sudah mulai menjalin hubungan erat, mereka mulai saling mengungkapkan tentang dirinya.

4. Menyatakan perasaan

Di antara individu sudah terjalin hubungan yang terbuka, jujur, dan masing-masing individu menyatakan perasaanperasaan yang mendalam.

5. Hubungan puncak

Pengungkapan diri telah dilakukan secara mendalam, individu dapat menghayati perasaan yang dialami individu lainnya. 


\section{BAB 5}

\section{PERSEPSI SOSIAL (SOCIAL PERCEPTION)}

\section{Capaian Pembelajaran Mata Kuliah :}

a. Aspek Sikap dan Tata Nilai :

(1) Bertakwa kepada Tuhan Yang Maha Esa dan mampu menunjukkan sikap religious

(2) Berkontribusi dalam peningkatan mutu kehidupan bermasyarakat, berbangsa, bernegara, dan kemajuan peradaban berdasarkan Pancasila

(3) Menghargai keanekaragaman budaya, pandangan, agama dan kepercayaan serta pendapat atau temuan orisinal orang lain

b. Aspek Ketrampilan Umum :

(1) Menguasai konsep teoritis hubungan manusia dengan lingkungan sosialnya

(2) Menguasai konsep teoritik komunikasi antar pribadi dan komunikasi massa

c. Aspek Ketrampilan Khusus :

Mampu menerapkan pemikiran logis, kritis, sistematis, dan inovatif dalam konteks pengembangan atau implementasi ilmu pengetahuan dan teknologi yang memperhatikan dan menerapkan nilai humaniora

d. Aspek Penguasaan Pengetahuan :

Mampu memahami dan menjelaskan peranan Psikologi Sosial dalam proses interaksi sosial, serta menerapkan dalam menyelesaikan permasalahan sosial. 
Kegiatan apapun yang kita lakukan dalam interaksi sosial, misalnya olahraga, kuliah, dunia politik, dan sebagainya, kita semua aktif dan sebagai partisipan yang tertarik untuk melakukan persepsi sosial (social perception). Persepsi sosial merupakan sebuah proses dimana orang-orang datang untuk memahami orang lain (Kassin, et. al., 2008). Persepsi sosial merupakan sebuah proses untuk mencoba memahami orang lain (Baron \& Byrne, 2003). Persepsi sosial telah lama menjadi topik yang diminati para ahli psikologi sosial. Seringkali kita menghabiskan banyak waktu dan usaha untuk mencoba memahami perilaku orang lain. Terkadang penafsiran kita tepat, namun juga seringkali gagal dan keliru.

\section{A. Observasi : Elemen-elemen Persepsi Sosial}

Memahami orang lain tidaklah mudah, namun hal ini umum dan menjadi bagian penting dari kehidupan sehari-hari. Bahkan orang yang sehari-hari kita jumpai juga tidak mudah kita kenal dengan baik. Memahami teman kita tidak dapat dipahami hanya dari penampilannya. Upaya seseorang untuk memahami orang lain seperti seorang detektif yang mencoba untuk merekonstruksi berbagai peristiwa atau informasi yang diperolehnya, mengamati gerak-gerik target, dan selanjutnya menyimpulkan hasil pengamatannya selama ini. Pengamat social memahami orang lain melalui petunjuk-petunjuk secara tidak langsung, dimana petunjuk ini tercakup dalam elemenelemen persepsi social. Kassin, et. al., (2008) mengelompokkan sumber-sumber persepsi sosial dalam tiga elemen, sebagai berikut :

\section{Orang (person)}

Don't judge a book by its cover! Jangan menilai orang yang baru dikenal hanya dari penampilan luarnya saja ! Pernahkah kita bertemu seseorang untuk pertama 
kalinya dan dengan cepat membentuk kesan tentang orang tersebut berdasarkan informasi yang sekilas ? Mempersepsi seseorang bisa dilakukan dengan melihat penampilan fisiknya. Kita juga sering melakukan penilaian terhadap seseorang berdasarkan namanya (Suryanto, et. al., 2012). Misalnya kita bertemu seseorang yang memiliki nama dari Batak, kita bisa menyimpulkan perilakunya seperti warga etnis Batak pada umumnya.

Wajah seseorang kadang menarik perhatian secara lebih khusus dan membuat orang lain berbagi perhatian terhadap dirinya. Sudah sejak lama orang tertarik dengan fisiognomi, yaitu seni untuk membaca karakter orang melalui wajah. Dalam studi persepsi sosial tentang wajah manusia, peneliti menemukan bahwa orang dewasa yang memiliki wajah baby-face, besar, mata bulat, alis tinggi, dahi lebar, pipi bulat, kulit lembut, dan dagu bulat, cenderung terlihat hangat, baik hati, naif, lemah, jujur, dan submissive. Sebaliknya, orang dewasa dengan mata kecil, alis rendah, dahi kecil, kulit kusut, dan dagu sudut, terlihat sebagai seorang yang kuat, lebih dominan, dan lebih kompeten (Berry \& Zebrowitz-McArthur, 1986, dalam Kassin, et. al., 2008).

Apa yang bisa dicermati dari temuan-temuan di atas ? Mengapa secara umum orang-orang secara cepat membuat penilaian tentang orang lain dari penampilannya (appearance) ? Terdapat tiga penjelasan yang memungkinkan tentang hal tersebut. Pertama, manusia secara genetik terprogram untuk merespon secara lembut terhadap tampilan kekanak-kanakan sehingga dalam kenyataannya bayi diperlakukan dengan penuh kasih sayang. Kedua, secara sederhana kita belajar untuk 
mengasosiasikan tampilan kekanak-kanakan dengan ketidakberdayaan (helplessness) dan kemudian menggeneralisasikan ekspektasi ini terhadap orang dewasa yang berpenampilan baby-face. Ketiga, kemungkinan terdapat hubungan yang jelas antara penampilan fisik dan perilaku (Kassin, et. al., 2008).

\section{Situasi}

Selain keyakinan yang kita pegang tentang seseorang, masing-masing dari kita memiliki gagasan yang telah ditetapkan tentang jenis-jenis situasi untuk memaknai dan memprediksi apa yang sedang terjadi. Situasi diumpamakan seperti catatan (scripts) kehidupan yang memungkinkan orang-orang mengantisipasi tujuan, perilaku, dan hasil (outcomes) yang mungkin terjadi dalam situasi tertentu (Abelson, 1981; Read, 1987; dalam Kassin, et. al., 2008). Berdasarkan pengalaman masa lalu, orangorang dengan mudah membayangkan urutan peristiwa pada situasi tertentu. Misalnya, saat menonton pertandingan sepakbola, kita sudah bisa membayangkan urutan peristiwa yang akan terjadi.

\section{Perilaku}

Langkah awal yang terpenting dalam persepsi sosial adalah mengenali (recognize) apa yang dilakukan seseorang pada situasi tertentu. Mengidentifikasi tindakan dari gerakan sangatlah mudah. Bahkan saat aktor berpakaian serba hitam bergerak di dalam ruangan gelap dengan sebuah titik lampu yang hanya terpasang pada sendi tubuh mereka, orang-orang secara cepat dan dengan mudah mengenali beberapa perilaku kompleks seperti berjalan, berlari, berlatih, dan terjatuh (Johansson, et. al., 1980, dalam Kassin, et. al., 2008). Barrett et. al. menyatakan bahwa 
kemampuan ini dijumpai pada orang-orang di semua budaya (Kassin, et. al., 2008).

\section{B. Komunikasi Nonverbal}

Pernahkan Anda berada dalam sebuah situasi dimana Anda berusaha untuk berkomuniasi tanpa menggunakan katakata ? Barangkali Anda pernah berinteraksi dengan orang yang tidak bisa mendengarkan, atau dengan seseorang yang jaraknya terlalu jauh untuk bisa mendengarkan apa yang Anda bicarakan. Meskipun tanpa menggunakan kata-kata, kita bisa menyimpulkan tentang pesan seseorang dan keadaan emosinya. Kita bisa menginterpretasikannya melalui komunikasi nonverbal yang ditunjukkan mereka. Menurut DePaulo, perilaku nonverbal relatif tidak bisa dikekang atau sulit untuk dikontrol, sehingga saat seseorang mencoba menyembunyikan perasaan yang sesungguhnya dari orang lain, perilaku itu tetap tampil melalui isyarat-isyarat nonverbal (Baron \& Byrne, 2003).

Penting juga untuk diingat, bahwa petunjuk nonverbal yang ditampilkan seseorang dapat mempengaruhi perasaan kita meskipun kita tidak secara sadar memperhatikan petunjuk tersebut, ataupun sengaja mencoba membaca perasaannya. Misalnya, ketika kita bertemu dengan teman yang menampilkan ekspresi wajah marah dan tekanan suara tinggi, kita juga bisa secara tiba-tiba mengekspresikan wajah marah dan tekanan suara kita juga tinggi. Komunikasi nonverbal memiliki efek penularan emosional. Sebagaimana hasil penelitian Neumann dan Strack (2000) menemukan bahwa ketika seseorang mendengarkan orang lain berpidato, nada suara pembicaranya (senang, sedih, netral) bisa mempengaruhi perasaan pendengar meskipun sebenarnya 
pendengar fokus pada isi pidato, bukan pada keadaan emosional pembicara. Gejala ini disebut dengan penularan emosional (emotional contagion), yaitu mekanisme yang mentransfer perasaan secara otomatis dari satu orang ke orang lain (Baron \& Byrne, 2003).

\section{Tipe-tipe atau Saluran Komunikasi Nonverbal}

Menurut Delamater dan Myers (2011), terdapat empat tipe atau saluran komunikasi nonverbal, yaitu sebagai berikut :

\section{Paralanguage}

Merupakan semua aspek vokal dalam berbicara selain katakata, perilaku dalam bentuk vokal atau variasi ucapan, seperti kerasnya suara, kecepatan berbicara, jeda dalam berbicara, nada suara, tekanan suara, nafas, dan sebagainya. Isyarat paralinguistik diterima melalui pendengaran (auditori).

\section{Bodylanguage atau kinesics (kinesik)}

Yakni gerakan diam dari anggota tubuh, seperti gestur (gesture), ekspresi wajah (facial expression), tatapan mata (eye gaze), gerakan kaki, anggukan, pergeseran postur, jabat tangan, sentuhan, dan sebagainya. Isyarat kinesik diterima melalui visual.

\section{Interpersonal spacing atau proxemics (proksemik)}

Merupakan posisi diri kita pada jarak dan sudut dari orang lain, seperti jarak berdiri dekat atau jauh, posisi menghadap kepala, menggunakan penghambat jarak dengan buku atau objek lain, dan sebagainya. Secara umum, semakin akrab seseorang dengan orang lain, semakin dekat jaraknya dalam berinteraksi. Kita cenderung menjaga jarak untuk menunjukkan ketidaktertarikan atau ketidaksukaan kita. 
4. Aspek-aspek personal lainnya yang sengaja dipilih atau diciptakan individu, seperti pilihan pakaian, gaya rambut, makeup, contact lense, parfum, dan sebagainya.

\section{Komunikasi Nonverbal Multi-saluran}

Dalam interaksi sehari-hari, kita biasanya menerima informasi dari beragam saluran dalam waktu bersamaan. Archer dan Akert menemukan bahwa orang mampu menginterpretasikan isyarat-isyarat yang ditampilkan melalui beragam saluran komunikasi nonverbal dengan cukup tepat, dengan menggunakan berbagai petunjuk atau tanda meski terdapat perbedaan pada beberapa tipe orang (Sarwono \& Meinarno, 2009). Misalnya orang yang ekstrovert lebih baik kemampuannya dibandingkan orang yang introvert. Dengan membandingkan informasi-informasi dari beragam saluran yang berbeda, bisa meningkatkan ketepatan penafsiran terhadap tingkah laku nonverbal.

\section{Menggabungkan Komunikasi Nonverbal dan Verbal}

Saat kita berbicara di telepon, atau berteriak kepada teman yang berada di ruangan lain, kita terbatas berkomunikasi melalui verbal dan saluran paralingustik. Saat kita melambai untuk kedatangan atau keberangkatan penumpang di bandara, kita hanya menggunakan saluran visual. Bagaimanapun juga komunikasi melibatkan multi saluran. Informasi disampaikan secara bersamaan melalui verbal (kata-kata), paralinguistik, kinesik, dan petunjuk proksemik.

Apa yang menjadi permasalahan saat komunikasi menggabungkan saluran-saluran komunikasi yang berbeda ? Jika saluran-saluran yang berbeda tersebut konsiten dalam menyampaikan informasi, akan saling memperkuat satu 
dengan lainnya, dan komunikasi menjadi akurat. Namun jika saluran-saluran yang berbeda yang digunakan dalam menyampaikan informasi tersebut tidak konsisten, pesan yang disampaikan akan memunculkan kebingungan, atau bahkan memunculkan kecurigaan adanya penipuan (Delamater \& Myers, 2011).

\section{Atribusi (Attribution)}

Agar dapat berinteraksi secara efektif dengan orang lain, kita butuh mengetahui bagaimana yang mereka rasakan dan kapan mereka bisa dipercaya. Namun untuk memahami orang-orang dengan cukup baik untuk memprediksi perilaku mereka yang akan datang, kita juga harus mengidentifikasi faktor disposisi internal mereka : karakteristik yang stabil seperti trait kepribadian, sikap, dan kemampuan (Kassin, et. al., 2008).

Saat berinteraksi dengan orang lain, seringkali kita tidak hanya mengamati perilaku mereka dan dampak dari perilaku tersebut, namun kita juga mencari tahu mengapa mereka melakukan perilaku tersebut. Hal inilah yang dinamakan dengan atribusi, yaitu sebuah proses dimana seorang pengamat menyimpulkan penyebab dari perilaku orang lain. Misalnya, mengapa seseorang mengemudikan mobilnya dengan ugal-ugalan?

Dalam buku klasik yang berjudul The Psychology of Interpersonal Relations, Fritz Heider (1958) mengemukakan bahwa kita layaknya seorang ilmuwan, karena termotivasi untuk memahami orang lain dengan baik dalam rangka untuk mengelola kehidupan sosial kita, maka kita mengamati, menganalisis, dan menjelaskan perilaku orang lain tersebut. Penjelasan inilah yang dinamakan dengan atribusi, dan teori 
yang menjelaskan prosesnya disebut teori atribusi (attribution theory).

Tertarik dengan bagaimana orang-orang menjawab pertanyaan "mengapa", Heider menemukan penyebab khusus dari sebuah perilaku dalam dua kategori, yaitu personal (dispositional attribution) dan situasional (situational attribution). Atribusi personal terjadi ketika penyebab perilaku dikarenakan karakteristik internal individu, seperti karakteristik kepribadian, kemampuan, dan suasana hati (mood). Sedangkan atribusi situasional menyimpulkan bahwa penyebab perilaku seseorang karena faktor situasi atau eksternal. Misalnya, saat pertandingan sepakbola piala dunia tahun 2006, Zidane dengan kuat menyeruduk kepala lawannya (Italia). Apa yang menyebabkan Zidane melakukan tindakan tersebut ? Saat pengamat menyalahkan perilaku Zidane tersebut karena dia seorang pemain yang agresif dan mudah marah, inilah yang dimaksud dengan atribusi personal atau internal. Pada sebagian pengamat lain memberikan spekulasi bahwa tindakan Zidane karena dipicu oleh akumulasi frustrasi atau ucapan lawannya, maka ini yang termasuk dalam atribusi situasional atau eksternal.

\section{Teori Inferensi Korespondensi (Corespondent Inference Theory) Jones dan Davis}

Menurut Edward Jones dan Keith Davis (1965), masing-masing orang berusaha untuk memahami orang lain dengan mengamati dan menganalisa perilakunya. Teori inferensi korespondensi Jones dan Davis memperkirakan bahwa orang-orang berusaha untuk menyimpulkan (inferensi) sebuah perilaku, apakah perilaku tersebut sesuai dengan karakteristik personal pelaku yang stabil dan menetap untuk 
jangka waktu yang lama (Kassin, et. al., 2008). Apakah seseorang yang suka melakukan tindakan agresi karena memiliki watak yang jahat ? Apakah seseorang yang menyumbangkan uangnya untuk kegiatan amal memang seorang dermawan ? Untuk menjawab pertanyaan-pertanyaan seperti ini, orang melakukan penyimpulan berdasarkan pada tiga faktor.

Faktor pertama adalah derajat pilihan perilaku. Perilaku yang dipilih secara bebas lebih informatif daripada perilaku yang dipaksakan karena kondisi tertentu. Faktor kedua adalah ekspektasi dari sebuah tindakan. Seperti yang telah dijelaskan sebelumnya, bahwa sebuah tindakan memberikan informasi lebih banyak tentang seseorang saat tindakan itu bersumber dari norma daripada saat perilaku tersebut khas atau unik. Menurut Jones dan Davis, kita bisa memperhatikan tindakan yang memiliki tingkat harapan sosialnya (social desirability) rendah dibandingkan yang tingkat harapan sosialnya tinggi. Dengan kata lain, kita bisa belajar banyak tentang orang lain melalui tindakannya yang tidak biasa dilakukan oleh kebanyakan orang pada umumnya. Faktor yang ketiga, adalah efek niat atau konsekuensi dari perilaku seseorang. Tindakan yang menghasilkan banyak hasil sesuai yang diharapkan masyarakat tidak mengungkapkan motif khusus seseorang, dibandingkan jika sebuah tindakan dengan hasil tunggal (Newtson, 1974, dalam Kassin, et. al., 2008). Dengan kata lain, kita bisa fokus pada tindakan yang menunjukkan efek yang hanya dapat disebabkan oleh satu faktor spesifik dan bukan karena banyak faktor lain. Tindakan yang menghasilkan efek tidak umum ini lebih informatif karena bisa mengabaikan pengaruh faktor-faktor lain. Misalnya, kita sulit untuk memastikan secara tepat mengapa seseorang tetap 
bekerja pada sebuah pekerjaan yang menyenangkan, gajinya tinggi, dan lokasinya menarik (tiga hasil yang diinginkan, masing-masing cukup untuk menjelaskan tingkah laku). Sebaliknya, kita mungkin merasa lebih pasti tentang mengapa seseorang tetap bekerja pada pekerjaan yang tidak menyenangkan, gajinya rendah, namun lokasinya menarik (hanya satu hasil yang memang diinginkan).

\section{Teori Korespondensi (Covariation Theory) Harold Kelley}

Teori inferensi korespondensi berusaha untuk mendeskripsikan bagaimana penerima pesan (perceiver) mencoba untuk menjelaskan karakteristikpersonal individu dari kejadian perilaku. Bagaimanapun, perilaku bisa diatribusikan tidak hanya dari faktor personal, namun juga faktor situsional. Menurut Kelley (dalam Brehm \& Kassin, 1996), orang-orang membuat atribusi dengan menggunakan prinsip-prinsip kovariansi (covariation principle). Agar sesuatu bisa menjadi penyebab perilaku, maka prinsip-prinsip tersebut harus ada, namun jika tidak ada maka tidak bisa dikatakan sebagai penyebab sebuah perilaku. Terdapat tiga jenis informasi kovariansi yang digunakan dalam melakukan atribusi, yaitu konsensus (consensus), kekhasan (distinctiveness), dan konsistensi (consistency).

Layaknya berpikir seperti seorang ilmuwan, Anda akan mencari informasi konsensus (consensus) untuk melihat bagaimana orang yang berbeda bereaksi terhadap stimulus yang sama. Menurut Baron dan Byrne (2003), konsensus merupakan derajat kesamaan reaksi orang lain terhadap stimulus atau peristiwa tertentu dengan orang yang sedang kita amati. Semakin tinggi proporsi orang yang bereaksi serupa dengan pengamat, semakin tinggi tingkat konsensusnya. 
Berpikir seperti seorang ilmuwan, Anda mungkin juga ingin mencari informasi yang khas atau khusus (distinctiveness) untuk melihat bagaimana orang yang sama bereaksi terhadap stimuli atau peristiwa yang berbeda.

Terakhir, Anda mungkin mencari informasi konsistensi (consistency) untuk melihat apa yang terjadi pada sebuah perilaku pada waktu yang berbeda ketika orang dan stimulusnya sama, atau derajat kesamaan reaksi seseorang terhadap suatu stimulus atau peristiwa yang sama pada waktu yang berbeda.

Menurut teori Kelley, kita mengatribusi perilaku orang lain pada penyebab internal apabila tingkat konsensus dan kekhasan rendah namun konsistensinya tinggi. Sebaliknya, kita mengatribusi perilaku seseorang pada penyebab eksternal jika tingkat konsensus, kekhasan, dan konsistensinya tinggi. Kita juga biasa mengatribusi perilaku orang lain merupakan kombinasi antara faktor internal dan eksternal jika tingkat konsensus rendah namun tingkat kekhasan dan konsistensinya tinggi (Baron \& Byrne, 2003).

Berikut ini adalah contoh konkrit untuk memudahkan pemahaman Anda. Anda melihat dosen Anda marah-marah ke teman Anda. Anda bertanya-tanya : Mengapa si dosen bertingkah laku demikian ? Karena faktor internal atau eksternalkah ? Apakah dia memang suka marah ? Atau apakah memang teman Anda yang sering membuat masalah dengan siapapun ? Berdasarkan teori Kelley, penilaian Anda sebagai pengamat bergantung pada tiga tiga jenis informasi seperti yang diuraikan di atas. Jika kondisinya : (1) Anda mengamati ternyata dosen lain juga sering marah kepada teman Anda (konsensusnya tinggi), (2) Anda belum pernah melihat dosen Anda tersebut marah-marah kepada mahasiswa (kekhasannya 
tinggi), (3) Anda juga mengamati bahwa sang dosen pernah marah ke teman Anda tadi sebelumnya (konsistensinya tinggi). Dalam kasus di atas, dimana konsensus, kekhasan, dan konsistensi tinggi, Anda mengatribusi perilaku dosen pada faktor eksternal, yaitu teman Anda yang sering membuat masalah (trouble maker). Sebaliknya, jika kondisinya : (1) Dosen lain tidak pernah memarahi teman Anda (konsensusnya rendah), (2) Anda pernah bahkan sering melihat dosen Anda marah-marah kepada mahasiswa lainnya (kekhasannya rendah), (3) Anda pernah melihat sang dosen memarahi teman Anda tadi dalam situasi yang berbeda. Maka dalam kasus ini Anda bisa mengatribusikan perilaku dosen Anda disebabkan faktor internal (konsensus dan kekhasan rendah, konsistensi tinggi), yaitu dosen Anda memang suka marah.

Apakah model Kelley ini menjelaskan jenis-jenis informasi yang Anda cari ketika Anda berusaha untuk menentukan apa yang menyebabkan orang berperilaku seperti yang mereka lakukan ? Ya, itu sering terjadi. Penelitian menunjukkan bahwa orang-orang yang diinstruksikan untuk membuat atribusi tentang peristiwa tertentu, secara umum mengikuti logika kovariansi Kelley (Cheng \& Novick, 1990; Fosterling, 1992; McArthur, 1972, dalam Kassin, et. al., 2008).

\section{Bias-bias Atribusi}

Saat teori atribusi diusulkan pertama kali, para pencetus merepresentasikan dengan mengelaborasikan gambar alur (flow chart), formula, dan diagram sehingga banyak ahli psikologi social bertanya-tanya : Apakah orang benar-benar menganalisa perilaku dalam cara-cara yang diharapkan seperti computer ? Apakah orang memiliki waktu, motivasi, atau kapasitas kognitif untuk mengelaborasi dan 
berproses dengan penuh perhatian ? Jawabannya, kadang ya, kadang tidak. Sebagai orang yang melakukan persepsi social, kita memiliki keterbatasan kemampuan untuk memroses segala informasi yang relevan, atau kita mungkin kurang terlatih untuk menggunakan prinsip-prinsip teori atribusi. Lebih penting lagi, kita seringkali tidak berupaya untuk berpikir secara hati-hati tentang atribusi yang kita buat. Dengan penjelasan yang begitu banyak dan kita tidak memiliki banyak waktu dalam sehari, orang melakukan tindakan jalan pintas atau potong kompas (mental shortcut). Persoalannya adalah bahwa proses yang cepat itu menyebabkan terjadinya bias, bahkan tidak akurat (Kassin, et. al., 2003).

Berikut ini dijelaskan beberapa jalan pintas dan konsekuensi yang ditimbulkan menurut Kassin, et. al. (2003) :

\section{Heuristik kognitif (cognitive heuristic)}

Menurut Daniel Kahneman dan Amos Tversky, orang sering melakukan atribusi dan tipe penilaian social lainnya dengan menggunakan heuristic kognitif tertentu, dimana seseorang memroses informasi secara potong kompas sehingga penilaian yang dilakukan dapat cepat, namun seringkali mengalami kesalahan. Penjelasan lebih rinci tentang heuristik kognitif ini bisa dilihat di bab 6 (Kognisi Sosial).

2. Kesalahan atribusi mendasar (fundamental attribution error)

Pada bias ini, kita cenderung mempersepsikan tindakan orang lain disebabkan karena faktor personal atau internal (disposisional), dan mengabaikan peranan faktor eksternal atau situasi sebagai penyebab sebuah perilaku. 
3. Efek pelaku-pengamat (actor-observer effect) Tipe kesalahan atau bias atribusi ini menjelaskan bahwa adanya kecenderungan kita mengatribusi perilaku diri sendiri disebabkan faktor situasional (eksternal), sementara perilaku orang lain disebabkan karena faktor internal atau personal (disposisional).

4. Bias mengutamakan diri sendiri (self-serving bias)

Bias ini menjelaskan bahwa ada kecenderungan kita mengatribusi perilaku kita yang positif karena faktor internal atau personal, sementara untuk perilaku yang negatif kita atribusikan karena faktor eksternal atau situasional (Baron \& Byrne, 2003). 


\section{BAB 6 \\ KOGNISI SOSIAL (SOCIAL COGNITION)}

\section{Capaian Pembelajaran Mata Kuliah :}

a. Aspek Sikap dan Tata Nilai :

(1) Bertakwa kepada Tuhan Yang Maha Esa dan mampu menunjukkan sikap religious

(2) Berkontribusi dalam peningkatan mutu kehidupan bermasyarakat, berbangsa, bernegara, dan kemajuan peradaban berdasarkan Pancasila

(3) Menghargai keanekaragaman budaya, pandangan, agama dan kepercayaan serta pendapat atau temuan orisinal orang lain

b. Aspek Ketrampilan Umum :

(1) Menguasai konsep teoritis hubungan manusia dengan lingkungan sosialnya

(2) Menguasai konsep teoritik komunikasi antar pribadi dan komunikasi massa

c. Aspek Ketrampilan Khusus :

Mampu menerapkan pemikiran logis, kritis, sistematis, dan inovatif dalam konteks pengembangan atau implementasi ilmu pengetahuan dan teknologi yang memperhatikan dan menerapkan nilai humaniora

d. Aspek Penguasaan Pengetahuan :

Mampu memahami dan menjelaskan peranan Psikologi Sosial dalam proses interaksi sosial, serta menerapkan dalam menyelesaikan permasalahan sosial. 
Dalam berinteraksi dengan orang lain, kita menggunakan cara kerja pikiran kita (kognisi) untuk memahami lingkungan di sekeliling kita supaya kita dapat berfungsi di dalamnya secara adaptif. Kognisi semacam ini merupakan dasar dari kognisi sosial (social cognition). Kognisi sosial merupakan studi tentang bagaimana orang menginterpretasi, menganalisis, dan menarik kesimpulan (inferensi) dari informasi sosial yang ada di lingkungan (Taylor, et. al., 2009). Dayakisni dan Hudaniah (2003) menjelaskan bahwa kognisi sosial merupakan suatu proses yang melibatkan persepsi, evaluasi dan mengkategorisasikan orang lain. Membuat penilaian sosial tidak semudah yang dibayangkan. Seringkali informasi yang tersedia tidak lengkap, ambigu dan bertentangan satu dengan lainnya. Inilah yang menjadi persoalan utama dalam studi kognisi sosial sehingga kognisi sosial menjadi area penelitian penting dalam psikologi sosial.

\section{A. Skema (Schema)}

Manusia membutuhkan kemampuan untuk mempersepsi orang lain secara akurat, termasuk menafsirkan perilakunya. Namun kita memiliki waktu dan energi yang terbatas untuk mengevaluasi secara cermat terhadap masingmasing individu yang kita baru temui. Untuk mempermudah dan mempercepat pemrosesan informasi sosial, biasanya individu menggunakan skema (schema). Proses ini bisa dilakukan dengan cepat, efisien dan sering bersifat otomatis yaitu secara tidak sadar. Kita memandang orang lain, situasi, atau kejadian berdasarkan skema.

Skema (schema) merupakan seperangkat tatanan struktur pengetahuan atau pemahaman mengenai beberapa konsep atau stimulus. Fiske dan Taylor mengemukakan bahwa skema berisi pengetahuan tentang konsep, relasi antar 
berbagai pemahaman tentang konsep tersebut dan contohcontoh spesifiknya. Skema bisa berupa orang, peran sosial, diri sendiri, sikap terhadap objek tertentu, stereotip tentang kelompok tertentu, atau persepsi tentang kejadian umum (Taylor, et. al., 2009). Delamater dan Myers (2011) menjelaskan bahwa skema merupakan suatu struktur kognisi yang terorganisasi dengan baik terkait beberapa entitas sosial, seperti orang, kelompok, peran, atau kejadian.

\section{Jenis-jenis Skema}

Delamater dan Myers (2011) mengemukakan empat jenis skema, sebagai berikut :

\section{Skema orang (person schemas)}

Merupakan struktur kognitif yang mendeskripsikan tentang kepribadian orang, seperti introvert, ekstrovert, bersemangat, dan sebagainya. Skema ini memungkinkan kita untuk membuat ekspektasi tentang perilaku orang lain. Misalnya, ketika kita mendengar bahwa Adi termasuk orang yang bersemangat, kita bisa memperkirakan bahwa Adi mudah bergaul, optimis, dan percaya diri, meskipun kita belum memiliki informasi lengkap tentang Adi.

\section{Skema diri sendiri (self schemas)}

Merupakan struktur kognitif yang mengorganisasikan konsep kita tentang diri kita sendiri (Catrambon \& Markus, 1987; Markus, 1977, dalam Delamater \& Myers, 2011). Sebagai contoh, jika Anda memahami bahwa Anda adalah orang yang bebas (independent), Anda akan melihat diri Anda sebagai seseorang yang individualistis, tidak konvensional, dan asertiv. 


\section{Skema kelompok (group schemas)}

Disebut juga dengan stereotip (stereotypes), yaitu skema yang berkaitan dengan keanggotaan seseorang dalam sebuah kelompok tertentu atau kategori sosial (Hamilton, 1981). Skema ini memberikan ciri khusus terhadap kelompok orang tertentu. Stereotip menunjukkan atribut dan perilaku yang mempertimbangkan tipe keanggotaan dari kelompok atau kategori sosial.

\section{Skema peran (role scemas)}

Merupakan jenis skema yang berisi konsep tentang normanorma dan perilaku yang cocok atau pantas bagi orangorang dari berbagai kategori sosial atau posisi atau status. Skema peran menunjukkan atribut dan perilaku tipal orang yang menduduki sebuah peran tertentu dalam sebuah kelompok. Skema ini melibatkan pada cara kita mengharapkan orang-orang untuk melakukan tindakan saat mereka memainkan peran tertentu.

\section{Skema kejadian atau naskah (event schemas or scripts)}

Skema ini berisi pengetahuan tentang tipe urutan kejadian atau situasi social (suatu pesta, pertandingan sepakbola, wawancara pekerjaan). Skema ini membantu kita memahami dan mengingat beberapa kejadian (Brigham, 1991, dalam Dayakisni \& Hudaniah, 2003).

\section{Keuntungan Permrosesan Skematis}

Menurut Taylor, et. al., (2009), pemrosesan skematis memiliki beberapa keuntungan, sebagai berikut :

\section{Memroses informasi}

Skema penting karena membantu kita memroses banyak informasi secara cepat dan efisien. 


\section{Membantu mengingat}

Memori sering bekerja dengan baik saat kita memiliki representasi skematis dari kejadian atau orang di masa lalu, karena skema memberikan banyak detil tentang hal tersebut.

\section{Mempercepat pemrosesan}

Ketika seseorang memiliki sebuah skema tentang orang atau situasi tertentu, akan memudahkan mereka untuk memmroses informasi yang relevan dengan skema tersebut. Hal ini bisa terjadi jika informasinya konsisten dengan skema (Dayakisni \& Hudaniah, 2003). Dalam beberapa kasus, mengulang ingatan skema akan memperlambat kelancaran pemrosesan informasi karena diperkenalkannya informasi yang jauh lebih rumit.

4. Membantu inferensi otomatis

Pemrosesan skematis dapat terjadi hamper secara otomatis, tanpa usaha sadar.

5. Menambah informasi

Sebuah skema bisa membantu kita mengisi informasi yang hilang saat terdapat kesenjangan (gap) dalam pengetahuan kita.

6. Membantu interpretasi

Skema memberikan informasi domain tertentu yang berkaitan dengan informasi lain yang relevan dengan domain tersebut.

\section{Memberikan ekspektasi}

Skema bisa memuat ekspektasi terkait apa yang akan terjadi. 


\section{Memuat perasaan}

Skema yang kita memiliki akan memuat perasaan kita tentang isi dari skema. Penggunaan skema tertentu bisa menimbulkan respon emosional tertentu (schema-driven affect).

Delamater dan Myers (2011) mengemukakan empat keuntungan pemrosesan skematis, yaitu :

1. Mempengaruhi kapasitas kita untuk mengingat (recall) informasi dengan membuat jenis-jenis fakta tertentu lebih menonjol dan lebih mudah untuk diingat.

2. Membantu kita dalam memroses informasi dengan lebih cepat.

3. Membimbing kita dalam membuat penyimpulan (inferences) dan penilaian (judgements) tentang orang dan objek.

4. Membantu kita mengurangi ambiguitas dengan menyediakan sebuah cara untuk menginterpretasikan elemen yang ambigu dalam sebuah situasi. Sekali kita telah menerapkan sebuah skema dalam situasi, keputusan kita tentang bagaimana berinteraksi di dalamnya menjadi lebih mudah (Mayer, et. al., 1993, dalam Delamater \& Myers, 2011).

\section{Kelemahan Skema}

Meskipun penggunaan skema memberikan banyak keuntungan, namun skema juga memiliki beberapa kelemahan. Terdapat beberapa kelemahan atau kerugian menggunakan skema menurut Delamater \& Myers (2011), yaitu :

1. Orang-orang terlalu menerima informasi yang sesuai secara konsisten dengan skema. 
2. Ketika dihadapkan dengan informasi yang hilang atau tidak sesuai dengan skema, orang-orang akan mengisi kesenjangan (gap) dalam pengetahuan dengan menambahkan elemen yang konsisten dengan skema mereka. Terkadang ditambahkan elemen berubah menjadi keliru atau secara faktual tidak tepat. Ketika hal ini terjadi, tentu menyebabkan interpretasi atau penyimpulan (inferences) tentang orang, kelompok, atau kejadian menjadi tidak akurat.

3. Karena orang-orang sering menolak untuk membuang atau merevisi skema, mereka kadang menerapkan skema tersebut kepada orang atau peristiwa meskipun saat skema tersebut tidak sesuai fakta dengan baik. Penerapan yang keliru dari sebuah skema akan menyebabkan karakterisasi dan penyimpulan yang keliru, dan hal ini dapat menghasilkan ketidakpantasan atau respon yang tidak fleksibel terhadap orang lain, kelompok, atau peristiwa.

\section{B. Heuristik (heuristics) dan Pemrosesan Otomatis}

Dunia sosial menyediakan informasi sosial dalam jumlah yang banyak dan kompleks, sementara kita dituntut untuk bisa mengolah informasi sosial tersebut dalam waktu yang singkat. Tekanan efisiensi seringkali menyebabkan orangorang mengandalkan skema yang dimiliki untuk mengolah informasi social tersebut. Pemrosesan informasi sosial dengan menggunakan skema disebut sebagai heuristik (heuristics).

Heuristik dapat diartikan sebagai aturan sederhana untuk membuat keputusan kompleks atau untuk menarik kesimpulan secara tepat dan tanpa usaha yang berarti (Baron \& Byrne, 2003). Heuristik merupakan upaya untuk mempersingkat atau memotong proses mental menjadi lebih 
pendek, agar bisa keluar dari lingkungan sosial yang kompleks (Dayakisni \& Hudaniah, 2003).

\section{Tipe-tipe Strategi Heuristik}

Terdapat beberapa tipe strategi heuristik yang secara umum digunakan oleh orang-orang :

\section{Heuristik keterwakilan (heuristic representativeness)}

Membuat penilaian berdasarkan aturan yang relatif sederhana, yaitu semakin mirip seseorang dengan ciri-ciri khas orang-orang dari suatu kelompok, semakin mungkin individu tersebut menjadi bagian dari kelompok tersebut (Baron \& Byrne, 2003).

Dalam menilai orang lain, seringkali kita mempertimbangkan terlebih dulu apakah orang tersebut termasuk bagian dari kategori kelompok tertentu dengan mencocokkan kesamaan orang tersebut dengan skema yang kita miliki tentang tipe anggota sebuah kelompok (prototype). Kita mencocokkan informasi dari penampilan orang lain dengan skema kita untuk menentukan apakah orang tersebut mewakili (representative) skema itu (Dayakisni \& Hudaniah, 2003).

Keterwakilan heuristis membantu seseorang untuk menentukan apakah orang atau kejadian tertentu merupakan contoh dari skema tertentu. Misalnya, saat kita pertama kali bertemu dengan seseorang, biasanya kita akan menilai apakah dia termasuk orang yang baik atau tidak, melalui penampilan dan perilakunya. Selanjutnya kita mencocokkan orang tersebut dengan skema yang kita miliki tentang orang baik dan tidak. 
Strategi heuristik ini bisa mendorong kita pada kesalahan. Penggunaan yang berlebihan bisa mengarahkan pada stereotip (stereotype).

\section{Heuristik ketersediaan (availability heuristics)}

Merupakan jenis heuristik yang menggunakan contohcontoh yang mudah diingat atau jumlah informasi yang dapat kita ingat dengan cepat sebagai pedoman untuk mengambil kesimpulan (Taylor, et. al., 2009). Heuristik tipe ini digunakan saat kita menjawab pertanyaan "berapa sering", "berapa banyak", dan kita bisa menjawab secara cepat dengan menggunakan sampel informasi yang telah tersedia dalam ingatan kita untuk melihat berapa banyak contoh yang ada di dalamnya (Dayakisni \& Hudaniah, 2003).

Misalnya, untuk menentukan kemungkinan terjadinya orang yang meninggal karena merokok. Kemungkinan kita memiliki contoh kejadian sahabat kita yang meninggal karena merokok, sehingga kita menyimpulkan resiko meninggal kemungkinan besar terjadi.

Bias yang muncul dalam strategi heuristik ini terkait jumlah informasi yag berdampak pada generalisasi. Jika informasi yang tersedia sedikit, bisa mendorong pada terjadinya estimasi yang keliru (bias) menyangkut tingkat resiko yang diputuskan. Jumlah sampel orang atau kejadian yang kecil tersebut kemudian digeneralisasikan sehingga mengakibatkan terjadinya overestimasi.

\section{Heuristik simulasi (simulation heuristics)}

Merupakan jenis heuristik yang digunakan untuk berbagai macam tugas, seperti prediksi ("Apa yang akan dikatakan pimpinan"), kausalitas (Mandel \& Lehman, 1996, dalam 
Taylor, et. al., 2009), dan respon afektif (Kahneman \& Miller, 1986, dalam Taylor, et. al., 2009).

\section{Heuristik patokan dan penyesuaian}

Strategi heuristik yang digunakan saat kita berusaha menilai berdasarkan informasi yang ambigu, seringkali kita mengurangi ambiguitas ini dengan menggunakan poin referensi atau patokan kemudian menyesuaikannya. Dalam melakukan penilaian sosial, seringkali kita dihadapkan pada informasi tentang situasi sosial yang ambigu. Patokan bisa membantu untuk meninterpretasikan makna informasi dan perilaku yang ambigu tersebut (Mussweiler, et. al., 2000, dalam Taylor, et. al., 2009).

Misalnya, untuk menilai seberapa kemandirian teman, kita menilai berdasarkan seberapa kemandirian diri kita sendiri.

\section{Bias-bias Penggunaan Heuristik}

Penggunaan heuristik memang memberikan keuntungan kepada kita karena bisa mempercepat pemrosesan informasi sosial. Namun demikian, penggunaan heuristik juga menimbulkan kesalahan-kesalahan (bias) dalam memroses informasi secara tidak akurat. Beberapa bias yang terjadi dalam pemrosesan informasi sosial menggunakan heuristik, antara lain :

\section{Kesalahan generalisasi (generalization fallacies)}

Merupakan kecenderungan melakukan overgeneralisasi dari kasus-kasus individual atau dari sampel kecil dan berdasarkan pengalaman pribadi. Primary effect merupakan salah satu contoh kasus dari gejala generalization fallacies, yaitu penilaian kita terhadap seseorang atau perilaku berdasarkan pada kesan pertama, dimana kesan pertama ini bisa membawa kita pada 
interpretasi selanjutnya yang keliru dan menyesatkan (Dayakisni \& Hudaniah, 2003).

\section{Keteguhan keyakinan (perseverance of beliefs)}

Kita cenderung mengukuhi atau memelihara keyakinan (belief) yang kita miliki meskipun kita memperoleh informasi baru (Kassin, et. al., 2008).

\section{Hallo effect}

Kecenderungan kita saat membuat keputusan tentang orang lain yang tidak kita kenal, atau ketika kita memiliki informasi yang sedikit, sehingga kesan umum yang kita miliki tentang seseorang sebagai orang yang baik atau buruk akan mempengaruhi persepsi kita tentang beberapa ciri trait yang lebih khusus dari orang tersebut (Brigham, 1991).

\section{Bias negativitas (negativity bias)}

Kita memiliki sensitivitas yang besar terhadap informasi yang negatif daripada informasi yang positif (Baron \& Byrne, 2003). Hasil penelitian menunjukkan bahwa informasi negatif akan menonjol dalam ingatan kita dibandingkan informasi positif (Kunda, 1999, dalam Baron \& Byrne, 2003). Mengapa demikian ? Berdasarkan perspektif evolusi dapat dipahami bahwa informasi negative merefleksikan hal-hal di sekitar lingkungan yang bisa mengancam keselamatan atau kesejahteraan kita. Oleh karena itu, penting bagi kita untuk sensitif terhadap informasi seperti ini agar kita mampu merespon dengan cepat.

\section{Bias optimistik (optimistic bias)}

Kecenderungan kita untuk mengharapkan agar segala sesuatu dapat berakhir dengan baik (Baron \& Byrne, 2003). Hasil penelitian Shepperd, et. al. (1996) menunjukkan 
bahwa kebanyakan orang percaya bahwa mereka memiliki kemungkinan yang lebih besar dari orang lain untuk mengalami peristiwa positif, dan kemungkinan lebih kecil untuk mengalami peristiwa negatif.

\section{Self-fulfilling prophecy}

Merupakan sebuah proses dimana seseorang memiliki ekspektasi tentang orang lain akhirnya mengarahkan orang lain tersebut untuk bertingkah laku dalam cara yang sesuai dengan ekspektasi tersebut (Kassin, et. al., 2008). Darley dan Fazio menegaskan bahwa self-fulfilling prophecy ini merupakan sebuah fenomena yang sangat kuat. Bagaimana hal ini bisa dijelaskan ? Peneliti mengindikasikan bahwa terjadinya fenomena ini melalui tiga tahap. Pertama, perceiver membentuk sebuah kesan pada target (sebuah kesan yang mungkin disadarkan pada interaksi dengan target atau informasi lain. Kedua, perceiver bertingkah laku dalam cara yang konsisten dengan kesan pertamanya. Ketiga, orang yang menjadi target secara tidak tertulis menyesuaikan perilakunya pada perilaku perceiver. 


\section{BAB 7}

\section{SIKAP (ATTITUDES)}

\section{Capaian Pembelajaran Mata Kuliah :}

a. Aspek Sikap dan Tata Nilai :

(1) Bertakwa kepada Tuhan Yang Maha Esa dan mampu menunjukkan sikap religious

(2) Berkontribusi dalam peningkatan mutu kehidupan bermasyarakat, berbangsa, bernegara, dan kemajuan peradaban berdasarkan Pancasila

(3) Menghargai keanekaragaman budaya, pandangan, agama dan kepercayaan serta pendapat atau temuan orisinal orang lain

b. Aspek Ketrampilan Umum :

(1) Menguasai konsep teoritis hubungan manusia dengan lingkungan sosialnya

(2) Menguasai konsep teoritik komunikasi antar pribadi dan komunikasi massa

c. Aspek Ketrampilan Khusus :

Mampu menerapkan pemikiran logis, kritis, sistematis, dan inovatif dalam konteks pengembangan atau implementasi ilmu pengetahuan dan teknologi yang memperhatikan dan menerapkan nilai humaniora

d. Aspek Penguasaan Pengetahuan :

Mampu memahami dan menjelaskan peranan Psikologi Sosial dalam proses interaksi sosial, serta menerapkan dalam menyelesaikan permasalahan sosial. 
Para ahli psikologi sosial memandang sikap sebagai sesuatu yang penting dalam kehidupan sosial. Mereka menempatkan sikap sebagai isu sentral dalam kajian psikologi sosial karena beberapa alasan (Baron \& Byrne, 2003). Pertama, karena sikap sangat mempengaruhi pemikiran sosial kita, meskipun sikap tersebut tidak selalu direfleksikan dalam tingkah laku yang nampak (overt behavior). Kedua, sikap seringkali mempengaruhi tingkah laku kita. Misalnya, bagaimana sikap Anda terhadap presiden saat ini ? Jika sikap Anda negatif, Anda tidak akan memberikan suara bagi dia jika mencalonkan kembali. Karena sikap dapat mempengaruhi perilaku, maka dengan memahami sikap yang dimiliki seseorang bisa membantu kita untuk memprediksi tingkah laku orang tersebut dalam konteks yang lebih luas.

\section{A. Definisi Sikap (Attitudes)}

Masing-masing individu memiliki reaksi positif maupun negatif terhadap orang, objek, dan ide-ide tertentu (Kassin, et. al., 2008). Reaksi ini dinamakan dengan sikap (attitudes). Sikap merujuk pada evaluasi kita terhadap berbagai aspek dunia sosial, serta bagaimana evaluasi tersebut memunculkan rasa suka atau tidak suka terhadap isu, ide, orang, kelompok sosial, dan objek (Baron \& Byrne, 2003). Ajzen mengemukakan bahwa sikap adalah sebuah kecenderungan (predisposisi) untuk bereaksi terhadap sebuah objek tertentu secara umum dalam cara favorable atau unfavorablel. Sikap seseorang mempengaruhi caranya dalam mempersepsi dan bertindak terhadap dunia.

Sebuah sikap bisa positi, negatif, atau gabungan penilaian terhadap sebuah objek, diekspresikan pada beberapa level intensitas, seperti tidak lebih, tidak lebih. Suka, cinta, tidak suka, benci, dan sebagainya merupakan jenis-jenis kata yang 
digunakan orang-orang untuk mendeskripsikan sikap mereka. Misalnya, apakah Anda menyukai music rock atau jazz ? Apakah Anda lebih suka olahraga sepakbola atau basket?

Seringkali sikap direfleksikan dalam tindakan kita, meskipun terkadang tidak selalu demikian. Mengapa ? Sikap seringkali ambivalen, yaitu secara nyata kita melakukan evaluasi terhadap objek, isu, orang atau kejadian tidak selalu seragam positif atau negatif, namun evaluasi tersebut seringkali tercampur dari dua reaksi, baik positif maupun negatif sekaligus (Baron \& Byrne, 2003). Penting untuk disadari bahwa sikap tidak bisa begitu saja direpresentasikan sepanjang kontinum tunggal, sepenuhnya positif atau sepenuhnya negatif. Sikap kita bisa bervariasi dalam kekuatan keduanya, antara dimensi positif dan negatif. Dengan kata lain, kita bisa bereaksi terhadap sesuatu dengan afek positif, dengan afek negatif, dengan ambivalen (kuat namun emosinya campuran), atau dengan apatis dan pengabaian (Cacioppo, et. al.,1997, dalam Kassin, et. al., 2008). Beberapa orang lebih dari yang lain, terganggu oleh tipe yang tidak konsisten ini. Kenyataannya, kadang kita bisa memiliki kedua reaksi positif dan negatif terhadap objek sikap yang sama tanpa merasa berkonflik, seperti saat kita menyadari terhadap satu reaksi namun tidak dengan yang lain. Menurut Wilson, seseorang yang terbuka secara positif tehadap minoritas rasial namun tidak secara sadar menyembunyikan prasangka merupakan sebuah kasus dalam poin ini (Kassin, et. al., 2008).

Setiap orang secara rutin membentuk positif dan atau negatif penilaian terhadap orang, tempat, objek, dan ideide yang mereka temui. Proses ini seringkali terjadi dengan segera dan otomatis, seperti sebuah tindakan refleks (Bargh et. 
al., 1996; Cunningham, et. al., 2003; Duckworth, et. al., 2002, dalam Kassin, et. al., 2008).

\section{B. Komponen-komponen Sikap}

Delamater dan Myers (2011) mengemukakan bahwa sikap memiliki tiga komponen sebagai berikut :

\section{Komponen kognitif}

Merupakan komponen yang meliputi pengetahuan atau informasi yang dimiliki seseorang tentang objek sikapnya. Sebuah sikap mencakup label objek, aturan untuk menerapkan label tersebut, dan sebuah set kognisi atau struktur pengetahuan yang diasosiasikan dengan label. Dari pengetahuan ini akan membentuk sebuah keyakinan tertentu tentang objek sikap.

\section{Komponen evaluasi}

Sikap juga memiliki komponen evaluatif atau afektif, yang berkaitan dengan rasa senang atau tidak senang, dan berhubungan erat dengan nilai-nilai kebudayaan atau system nilai yang dimiliki seseorang (Dayakisni \& Hudaniah, 2003). Komponen ini memiliki kedua arah (positif atau negatif) dan sebuah intensitas (sangat lemah hingga sangat kuat). Komponen evaluasi ini membedakan sebuah sikap dari tipe elemen kognitif yang lain.

\section{Komponen predisposisi perilaku}

Sebuah sikap memiliki kesiapan (predisposisi) untuk bereaksi atau kecenderungan untuk berperilaku terhadap objek. Misalnya, "Kelas itu membosankan", berimplikasi pada kecenderungan untuk menjauhi kelas. Orang-orang yang memiliki sikap tertentu, cenderung untuk bertingkah laku dalam cara-cara yang konsisten dengan sikap tersebut. 
Komponen kognitif, evaluatif, dan perilaku semuanya memiliki objek yang sama, sehingga ketiganya membentuk satu kesatuan yang relatif konsisten (Delamater \& Myers, 2011). Sikap seseorang terhadap sebuah objek sikap merupakan manifestasi dari konstelasi ketiga komponen tersebut yang saling berinteraksi untuk memahami, merasakan, dan berperilaku terhadap objek sikap (Dayakisni \& Hudaniah, 2003).

\section{Fungsi Sikap}

Delamater \& Myers (2011) menjelaskan beberapa fungsi sikap yang terpenting, sebagai berikut :

\section{Heuristik atau fungsi instrumental}

Kita mengembangkan sikap yang baik (favorable) terhadap objek agar membantu kita untuk memperoleh ganjaran (hadiah) dan sikap yang tidak baik (unfavorable) terhadap objek yang menggagalkan atau menghukum kita.

2. Menyediakan sebuah skema atau fungsi pengetahuan (knowledge function)

Karena dunia terlalu kompleks untuk kita pahami secara lengkap, kita mengelompokkan orang, objek, dan peristiwa ke dalam kategori atau skema dan mengembangkan sikap dengan sederhana (stereotip) yang mengarahkan kita memperlakukan individu sebagai anggota sebuah kategori. Sikap kita terhadap kategori (objek) tersebut memberikan makna kepada kita, dengan berdasarkan pada penyimpulan terhadap anggota kelompok atau kategori tersebut.

3. Mendefinisikan diri (self) dan mempertahankan harga diri (self-worth)

Beberapa sikap mengekspresikan nilai-nilai dasar yang dimiliki individu (identitas diri) dan memperkuat citra diri (self-image) individu. 


\section{Fungsi pertahanan ego (ego defensive function)}

Sikap bisa melindungi individu dari adanya informasi atau pemikiran atau perasaan tertentu yang tidak diinginkan tentang dirinya, atau mengancam citra diri individu. Misalnya, seseorang menunjukkan sikap menentang diskriminasi, untuk melindungi diri dari kenyataan bahwa sebenarnya dia melakukan diskriminasi terhadap orang lain.

\section{Pembentukan Sikap}

Hampir semua ahli psikologi sosial meyakini bahwa sikap dipelajari. Sikap bukan pembawaan, melainkan hasil interaksi antara individu dengan lingkungannya, sehingga sikap bersifat dinamis (Dayakisni \& Hudaniah, 2003). Faktor pengalaman individu dalam berinteraksi dengan individu lain merupakan faktor dominan yang membentuk sikap.

Terdapat beberapa teori yang menjelaskan tentang pembentukan sikap pada individu, yaitu :

\section{Teori Belajar}

Karena sikap terbentuk berdasarkan pengalaman individu dari proses interaksi sosial, maka jelas sikap itu terbentuk melalui proses belajar. Berikut prinsip-prinsip dalam teori belajar yang membentuk sikap individu.

\section{a. Pengondisiak klasik (classical conditioning)}

Melalui classical conditioning, orang akan memiliki reaksi sikap yang kuat terhadap objek sosial bahkan meski tanpa pengalaman secara langsung. Prinsip dari classical conditioning yaitu ketika sebuah stimulus muncul berulang-ulang diikuti stimulus lain, selanjutnya stimulus pertama akan dianggap sebagai tanda-tanda munculnya stimulus yang mengikutinya. 
Misalnya, seorang anak dapat bersikap negatif terhadap seseorang dari kelompok tertentu dengan melihat sikap orang tuanya secara berkali-kali, meskipun si anak belum pernah bertemu secara langsung dengan orang tersebut.

b. Pengondisian instrumental

(instrumental conditioning)

Merupakan proses pembelajaran dimana saat respon yang menimbulkan hasil positif atau mengurangi hasil negatif diperkuat. Ketika sebuah perilaku mendatangkan hasil yang menyenangkan bagi seseorang, maka perilaku tersebut akan diulang kembali. Sebaliknya, jika sebuah perilaku mendatangkan hasil yang tidak menyenangkan bagi seseorang, maka perilaku tersebut akan dihindari.

c. Belajar melalui pengamatan (observational learning) Individu mempelajari tingkah laku atau pemikiran baru dengan mengamati (mengobservasi) tingkah laku orang lain. Selain itu, sikap atau pandangan tertentu bisa dipelajari dari media massa (televisi, majalah, Koran, dan sebagainya). Sebagai contoh, sikap atau pandangan politik bisa dipelajari seseorang dari sikap atau pemikiran politik orang lain di media massa.

\section{Teori Perbandingan Sosial}

Menurut teori ini, terdapat kecenderungan diri kita untuk membandingkan diri kita sendiri dengan orang lain, untuk menentukan apakah sikap atau pandangan kita terhadap dunia sosial benar atau salah (Festinger, 1954, dalam Kassin, et. al., 2008). Kita cenderungan menyamakan sikap pandangan maupun sikap kita dengan mengambil ide-ide 
dan sikap dari orang lain. Ketika pandangan atau sikap kita disetujui orang lain, kita menganggap bahwa pandanagn atau sikap kita tepat. Jika orang lain memiliki sikap atau pandangan yang sama dengan kita, kita menganggap bahwa pandangan atau sikap tersebut pasti benar. Oleh sebab itu, kita seringkali mengubah sikap kita mendekati sikap orang lain.

\section{E. Pengukuran Sikap}

Pada tahun 1928, Louis Thurstone mempublikasikan sebuah artikel yang berjudul "Attitude Can Be Measured." Sebuah review penelitian membongkar lebih dari 500 metode yang berbeda untuk menentukan sikap individu (Fishbein \& Ajzen, 1972, dalam Kassin, et. al., 2008). Berikut dipaparkan beberapa cara untuk mengukur sikap seseorang (Kassin, et. al., 2008) :

\section{a. Pengukuran Lapor-Diri (self-report measures)}

Cara yang paling mudah untuk mengukur sikap seseorang tentang sesuatu adalah dengan bertanya. Metode ini bersifat langsung dan mudah. Namun, terkadang sikap terlalu kompleks untuk diukur dengan menggunakan pertanyaan tunggal. Sebuah permasalahan diakui oleh lembaga survey opini 99egati bahwa respon individu terhadap pertanyaan-pertanyaan tentang sikap bisa dipengaruhi oleh susunan kata-kata mereka, konteks, dan berbagai 99egati eksternal lain. Mengakui adanya kelemahan pada pengukuran pertanyaan tunggal, para peneliti yang mengkaji tentang opini 99egati dan 99egati pada akhirnya sering menggunakan kuesioner multi-item yang dikenal dengan skala sikap (attitude scales). Skala sikap ini memiliki beragam bentuk, dan bentuk yang paling 
terkenal adalah Skala Likert (Likert Scale), yang mengambil nama dari penemunya Rensis Likert.

Dalam Skala Likert, responden dihadapkan dengan sejumlah pernyataan tentang sikap terhadap sebuah objek dan mereka diminta untuk menandai pada sebuah skala multi-poin tentang seberapa kuat mereka setuju atau tidak setuju terhadap masing-masing pernyataan. Skor total dari sikap responden diperoleh dengan menjumlahkan respon mereka pada semua item.

Semua jenis pengukuran self-report mengasumsikan bahwa orang mengeskpresikan dengan jujur pendapat yang sebenarnya. Terkadang asumsi ini benar, namun seringkali tidak. Keinginan untuk menciptakan kesan yang baik terhadap orang lain, orang seringkali enggan untuk mengakui kegagalan mereka, keburukan, kelemahan, pendapat yang tidak umum, dan diskriminasi.

\section{b. Pengukuran Tertutup (covert measures)}

Merupakan jenis pengukuran kedua pada persoalan self-report adalah dengan mengumpulkan tidak langsung, yaitu pengukuran sikap secara tertutup yang tidak bisa dikontrol. Satu hal yang mungkin bisa dilakukan adalah menggunakan perilaku yang bisa diamati seperti ekspresi wajah, nada suara, dan bahasa tubuh.

Meskipun perilaku menyediakan tanda-tanda tertentu, hal ini masih jauh dari kesempurnaan sebagai sebuah pengukuran sikap. Terkadang, kita menganggukkan kepala untuk menunjukkan bahwa kita setuju, pada waktu lain, kita mengangguk untuk menunjukkan kesopanan. Yang menjadi persoalan adalah orang-orang memonitor 
perilakunya yang 101egati seperti mereka memonitor selfreport mereka. Namun bagimana dengan kondisi internal, berkaitan dengan rekasi fisiologis yang sulit atau tidak mungkin untuk dikendalikan ? Apakah tubuh mengkhianati bagaimana yang kita rasakan ? Pada waktu yang lalu, peneliti mencoba untuk mengaitkan sikap dari reaksi fisik yang tidak disadari, seperti pernapasan detak jantung, dan gerakan mata. Hasilnya tetap sama, bahwa pengukuran rangsangan (101egativ) mengungkapkan intensitas sikap seseorang terhadap sebuah objek, bukan mengukur apakah sikap itu positif atau 101egative. Pada rekaman fisiologis, cinta dan benci terlihat memiliki banyak kesamaan (Petty \& Cacioppo, 1983).

Meskipun pengukuran rangsangan (101egativ) fisiologis tidak dapat membedakan antara sikap positif dan negatif, alternatif lain pengukuran diperkenalkan, yaitu facial electromyography (EMG). Melalui EMG ini, kita bisa melihat perbedaan kontraksi otot pada wajah saat gembira maupun sedih.

Dari perspektif neurosains sosial, aktivitas elektrik di dalam otak juga bisa digunakan untuk mengukur sikap. Tahun 1929, Hans Burger menemukan sebuah mesin yang bisa mendeteksi, memperkuat, dan merekam aktivitas elektrik di dalam otak melalui elektroda yang ditempelkan pada permukaan kulit kepala. Instrumen ini dinamakan dengan electroencephalograph (EEG). Sekalipun harus banyak dibuktikan melalui penelitian, namun penemuan EEG ini memberikan kontribusi bagaimana sikap individu bisa digambarkan melalui aktivitas elektrik yang terjadi di dalam otak. 


\section{c. The Implicit Association Test (IAT)}

Tes ini dikembangkan oleh Anthony Greenwald, Mahzarin Banaji, Brian Nosek, dan yang lainnya, untuk mengukur beberapa sikap yang tidak disadari. IAT ini merupakan sebuah pengukuran dengan menggunakan kecepatan individu dalam mengasosiasikan pasangan sebuah konsep. Secara umum, orang akan lebih cepat memroses ketika wajah yang disukai dipasangkan dengan kata-kata yang positif, dan wajah yang tidak disukai dipasangkan dengan kata-kata negatif. Tes ini hanya membutuhkanwaktu sepuluh menit. Ketika sudah selesai mengerjakan, kita akan menerima hasil tes dan penjelasan hasil tes tersebut.

\section{F. Hubungan Sikap Dan Tingkah Laku}

Orang-orang menerima begitu saja gagasan bahwa sikap mempengaruhi perilaku. Misalnya, adanya prasangka memicu tingkah laku negatif dari diskriminasi. Berawal dari asumsi ini, hubungan antara sikap dan tingkah laku jauh dari sempurna, atau tidak selalu sesuai dengan yang diharapkan bahwa sikap mempengaruhi perilaku seseorang (Kassin, et. al., 2008).

Richard LaPierre (1934) seorang ahli sosiologi yang pertama kali memperhatikan bahwa sikap dan tingkah laku tidak selamanya berhubungan secara langsung. Pada tahun 1930-an LaPierre mencoba membuktikan hal ini dengan melakukan penelitian pada pasangan muda Cina Amerika. Meskipun saat itu prasangka terjadi secara meluas pada masyarakat Asia, pasangan tersebut hanya menerima sekali perlakuan diskriminatif selama tiga bulan peneltian (Kassin, et. al., 2008). 
Studi yang dilakukan LaPierre menjadi studi pertama yang mengungkapkan lemahnya hubungan antara sikapa dan tingkah laku. Tahun 1969, Allan Wicker mereview sebuah penelitian terapan dan menyimpulkan bahwa sikap dan perilaku memiliki korelasi yang lemah (Kassin, et. al., 2008).

Berdasarkan pada beberapa studi meta-analisis dari para peneliti di atas, Laura Glasman dan Dolores Albarracin (2006, dalam Kassin, et. al., 2008) mengidentifikasi beberapa kondisi yang bisa memperkirakan bahwa sikap secara jelas mempengaruhi tingkah laku individu selanjutnya, yaitu sikap dalam konteks (attitudes in context) dan kekuatan sikap (strength of the attitude).

\section{Sikap dalam Konteks (attitudes in context)}

Icek Ajzen dan Martin Fishbein (1977, dalam Brehm \& Kassin, 1996) menemukan bahwa sikap berkorelasi dengan perilaku hanya ketika pengukuran sikap dilakukan dengan memasangkan perilaku yang lebih spesifik dalam pertanyaanpertanyaan. Sikap diukur dalam serangkaian pertanyaan dari pertanyaan yang sangat umum ("Bagaimana yang Anda rasakan tentang upaya untuk mengendalikan kelahiran ?") hingga pertanyaan yang sangat spesifik ("Bagaimana yang Anda rasakan tentang penggunaan pil KB selama dua tahun ke depan?").

Kaitan antara perasaan kita dengan perilaku kita seharusnya juga ditempatkan dalamkonteks yang lebih luas. Perilaku sosial tidak hanya dipengaruhi oleh sikap, namun juga faktor-faktor lain. Hal ini dijelaskan oleh Ajzen (1991) dalam teorinya tentang tinngkah laku terencana (theory of planned behavior). Menurut teori ini, sikap mempengaruhi perilaku kita melalui sebuah proses kesengajaan untuk mengambil 
keputusan, dan dampaknya terbatas dalam empat aspek, sebagai berikut :

1. Kekhususan sikap, bahwa sikap bisa mempengarui perilaku sejauhmana sikap tersebut terfokus pada objek atau situasi tertentu dibandingkan pada hal-hal atau objek yang umum.

2. Norma subjektif (subjective norms), bahwa perilaku tidak hanya dipengaruhi oleh sikap namun juga oleh normanorma subjektif (subjective norms), yaitu keyakinan kita tentang apa yang dipikirkan oleh orang lain tentang apa yang seharusnya kita lakukan.

3. Sikap menimbulkan perilaku hanya saat kita merasakan bahwa perilaku tersebut berada dalam kontrol kita.

4. Meskipun sikap berkontribusi pada intensitas perilaku dalam cara-cara tertentu, orang seringkali tidak bisa menindaklanjuti niat mereka.

\section{G. Persuasi Melalui Komunikasi (Persuasive Communication)}

Hampir setiap hari kita terlibat dalam proses pengubahan sikap. Iklan makanan di televisi, koran, majalah, kampanye politik, dan sebagainya merupakan contoh upayaupaya yang dilakukan untuk membentuk dan mengubah sikap melalui usaha persuasi, yaitu upaya yang bertujuan untuk mengubah sikap kita melalui berbagai jenis pesan (baron \& Byrne, 2003). Jika Anda ingin mengubah sikap seseorang terkait isu-isu tertentu, Anda bisa mencobanya dengan menggunakan sebuah komunikasi persuasif (persuasive communication).

\section{Faktor-faktor Yang Mempengaruhi Komunikasi Persuasif}

Kassin, et. al., (2008) mendeskripsikan tiga faktor penting dalam komunikasi persuasif, yaitu : 


\section{Sumber (komunikator)}

Faktor-faktor apa yang membuat komunikator secara umum lebih efektif dalam menyampaikan persuasinya, sementara komunikator lain tidak ? Terdapat dua atribut utama yang menyebabkan hal tersebut :

\section{a. Kredibilitas (credibility)}

Agar komuniakator terlihat kredibel, mereka harus memiliki dua karakteristik, yaitu kompeten (competence) atau keahlian (expertise) dan keterandalan (trustworthiness). Kompeten merujuk pada kemampuan (ability) komunikator. Orang-orang yang memiliki pengetahuan luas, cerdas, atau berbicara dengan baik atau memiliki prestasi yang mengagumkan merupakan komunikator persuasif karena keahliannya. Sedangkan keterandalan (trustworthiness) merujuk pada niat komunikator yang nampaknya tulus, tidak memiliki keinginan untuk memperoleh sesuatu untuk kepentingan dirinya sendiri karena perubahan sikap audiens yang mungkin terjadi.

\section{b. Daya tarik (likeability)}

Terdapat dua faktor yang menyebabkan seorang komunikator menarik, yaitu kesamaan (similarity) dan daya tarik fisik (physical attractiveness). Kita memiliki kesamaan dengan orang lain pada beberapa hal tertentu. Kita memiliki pandangan politik yang sama, kita memiliki makanan favorit yang sama, kita memiliki kesamaan pada jenis olahraga tertentu, dan sebagainya. Kesamaan dapat meningkatkan persuasi hanya saat kesamaan tersebut terlihat memiliki relevansi dengan isi dari komunikasi. Komunikator yang memiliki penampilan fisik yang menarik seringkali 
mampu meyakinkan orang lain, bukan karena kualitas argumentasinya (Chaiken, 1979; Pallak, 1983; Kahle \& Homer, 1985; dalam Brehm \& Kassin, 1996). Sejumlah penelitian menunjukkan bahwa salespersons laki-laki dan wanita yang menarik menimbulkan lebih banyak sikap positif dan keinginan membeli dari pembeli, apalagi saat mereka dari awal berkeinginan kuat untuk menjual.

\section{Pesan (message)}

Pesan yang disampaikan oleh komunikator akan cenderung lebih mudah diterima jika sesuai dengan pandangan atau nilai-nilai audiens. Namun, pada titik tertentu, kesenjangan antara isi pesan yang disampaiakan komunikator dengan pandangan audiens juga dapat menimbulkan perubahan sikap.

\section{Audiens (audience)}

Meskipun komunikator dan pesan merupakan faktor penting, namun komunikator juga harus memperhitungkan audiensnya. Strategi presentasi yang berhasil pada beberapa orang, bisa gagal saat dilakukan pada orang lain. Dampak yang ditimbulkan dari sebuah pesan ditentukan oleh dua kondisi, yaitu kepribadian dan harapan penerima pesan. Perbedaan individual (individual differences) mempengaruhi mudah atau tidaknya seseorang untuk dipersuasi. Individu dengan tingkat intelegensi yang tinggi memiliki need for cognition tinggi, lebih baik dalam memahami pesan yang kompleks, namun kurang bersedia menerima pengaruh sebuah pesan (Brigham, 1991, dalam Suryanto, et. al., 2012). Sedangkan individu dengan harga diri yang tinggi, umumnya sulit untuk dipersuasi, karena mereka memiliki kepercayaan diri yang kuat terhadap 
pendapatnya. Demikian juga dengan usia, secara umum remaja akhir atau dewasa awal mudah untuk dipersuasi, namun untuk individu yang berusia lanjut menunjukkan semakin sulit untuk merubah sikapnya (Dayakisni \& Hudaniah, 2003).

\section{H. Teori Disonansi Kognitif (Cognitive Dissonance Theory)}

Banyak ahli psikologi sosial mempercayai bahwa orang termotivasi secara kuat oleh sebuah keinginan untuk mencapai konsistensi kognitif (cognitive consistency), yaitu suatu keadaan di dalam pikiran dimana sebuah keyakinan, sikap, dan perilaku, semuanya saling mendukung satu sama lain (Abelson, et. al., 1968, dalam Kassin, et. al., 2008). Teori konsistensi kognitif melihat bahwa secara umum orang berpikir logis. Leon Festinger (1957) mengubah asumsi ini, dengan mengajukan teori disonansi kognitif (cognitive dissonance theory), yang menyatakan bahwa motivasi yang kuat untuk menjaga konsistensi kognitif bisa menimbulkan perilaku yang tidak rasional (irrasional behavior) dan menyimpang (maladaptive).

Menurut Festinger, kita memegang banyak kognisi tentang diri kita sendiri dan dunia di sekitar kita. Kognisi ini mencakup segala sesuatu yang kita ketahui tentang keyakinan, sikap, dan perilaku kita. Meskipun secara umum kognisi kita berdampingan dengan baik, terkadang mereka bertentangan antara satu dengan lainnya. Misalnya, kita memuji sesuatu yang sebenarnya tidak kita sukai. Dalam kondisi tertentu, diskrepansi seperti ini dapat membangkitkan kondisi ketegangan yang tidak menyenangkan, yang dikenal sebagai disonansi kognitif (cognitive dissonance). Disonansi kognitif 
merupakan sebuah keadaan yang tidak menyenangkan, ketika kita memiliki sikap yang tidak sesuai dengan tingkah laku kita.

Secara umum, orang tidak menyukai ketidakkonsistenan dalam dirinya dan merasa tidak nyaman dengan kondisi ini. Saat individu menyadari bahwa antara sikap dan perilakunya berbeda, individu termotivasi untuk melakukan upaya mengurangi disonansi tersebut. Menurut Festinger (dalam Baron \& Byrne, 2003), terdapat tiga mekanisme dasar atau cara untuk mengurangi keadaan disonan tersebut :

1. Mengubah sikap atau tingkah laku agar konsisten satu dengan lainnya.

2. Mencari informasi baru yang mendukung sikap atau tingkah laku (menambah elemen kognitif baru).

3. Melakukan trivialisasi (trivialization), yaitu mengabaikan ketidakkonsistenan yang terjadi, atau menganggap bahwa perbedaan antara sikap dan tingkah laku tidak penting. 


\section{BAB 8}

DAYA TARIK INTERPERSONAL (INTERPERSONAL ATTRACTION) DAN HUBUNGAN ERAT (CLOSE RELATIONSHIP)

\section{Capaian Pembelajaran Mata Kuliah :}

a. Aspek Sikap dan Tata Nilai :

(1) Bertakwa kepada Tuhan Yang Maha Esa dan mampu menunjukkan sikap religious

(2) Berkontribusi dalam peningkatan mutu kehidupan bermasyarakat, berbangsa, bernegara, dan kemajuan peradaban berdasarkan Pancasila

(3) Menghargai keanekaragaman budaya, pandangan, agama dan kepercayaan serta pendapat atau temuan orisinal orang lain

b. Aspek Ketrampilan Umum :

(1) Menguasai konsep teoritis hubungan manusia dengan lingkungan sosialnya

(2) Menguasai konsep teoritik komunikasi antar pribadi dan komunikasi massa

c. Aspek Ketrampilan Khusus :

Mampu menerapkan pemikiran logis, kritis, sistematis, dan inovatif dalam konteks pengembangan atau implementasi ilmu pengetahuan dan teknologi yang memperhatikan dan menerapkan nilai humaniora

d. Aspek Penguasaan Pengetahuan :

Mampu memahami dan menjelaskan peranan Psikologi Sosial dalam proses interaksi sosial, serta menerapkan dalam menyelesaikan permasalahan sosial. 
Pada waktu tertentu, kita akan melakukan hubungan interpersonal atau interaksi antara dua orang atau lebih. Dalam interaksi tersebut, terdapat aspek-aspek psikologis yang mendasarinya. Saat mengenal seseorang, akan muncul beberapa faktor yang mendorong ketertarikan antar indivdu, sehingga interaksi yang terjalin menjadi menyenangkan dan penting. Yang awalnya belum kenal, menjadi kenal, kemudian meningkat menjadi akrab atau erat.

\section{A. Mengapa Seseorang Berhubungan Dengan Orang Lain ?}

Keinginan untuk berinteraksi atau berhubungan dengan orang lain dilandasi oleh beberapa faktor psikologis sebagai berikut :

\section{Kebutuhan untuk berafiliasi (need for affiliation)}

Merupakan keinginan untuk membangun kontak sosial dengan orang lain (Mcdams, 1989, dalam Kassin, et. al.,2008). Kebutuhan ini mendorong perilaku social yang aktif dan terkendali dengan penekanan pada keluasan dan kuantitas hubungan sosial.

2. Kebutuhan untuk berhubungan secara intim atau akrab (need for intimacy)

Yaitu kebutuhan untuk memiliki hubungan yang hangat, dekat atau akrab, dan komunikatif. Adanya kebutuhan ini mendorong perilaku sosial yang pasif dan kurang terkendali dengan menekankan pada kedalaman dan kualitas hubungan sosial (Brehm \& Kassin, 1993, dalam Dayakisni \& Hudaniah, 2003).

\section{Penghargaan sosial (social rewards)}

Berhubungan dengan orang lain akan menghasilkan beberapa penghargaan sosial (social rewards), seperti dukungan emosional (perhatian, kasih sayang, rasa aman, 
dan sebagainya), menghindari kesepian (loneliness), serta standar untuk mengevaluasi pandangan, sikap, dan perilaku (terjadi dalam perbandingan sosial).

\section{B. Daya Tarik Interpersonal (Interpersonal Attraction)}

Dalam proses interaksi sosial, seseorang memiliki ketertarikan kepada orang lain karena adanya pengalaman yang berharga dengan orang lain tersebut. Pengalaman ini menciptakan respon emosi yang positif sehingga menguatkan keinginan seseorang untuk selalu bersama orang lain tersebut (Clore \& Byrne, 1974, dalam Suryanto, et. al., 2012).

Daya tarik interpersonal (interpersonal attraction) menurut Baron dan Byrne (2003) merujuk pada penilaian atau sikap seseorang terhadap orang lain, yang diekspresikan melalui dimensi dari sangat suka (strong liking) hingga sangat tidak suka (strong dislike). Untuk memudahkan pemahaman kita terkait penilaian ini, bisa dilihat pada tabel berikut :

Tabel 8.1. Dimensi Ketertarikan Interpersonal (Baron \& Byrne 2003)

\begin{tabular}{|l|l|l|}
\hline \multicolumn{1}{|c|}{$\begin{array}{c}\text { Derajat } \\
\text { Ketertarikan }\end{array}$} & Kategori Evaluasi & Contoh Interaksi \\
\hline Sangat suka & Teman (friend) & $\begin{array}{l}\text { Meluangkan waktu } \\
\text { bersama, } \\
\text { merencanakan } \\
\text { pertemuan }\end{array}$ \\
\hline Agak suka & $\begin{array}{l}\text { Kenalan dekat (close } \\
\text { acquaintance) }\end{array}$ & $\begin{array}{l}\text { Menyukai interaksi } \\
\text { saat bertemu }\end{array}$ \\
\hline Netral & $\begin{array}{l}\text { Kenalan biasa } \\
\text { (superficial } \\
\text { acquaintance) }\end{array}$ & $\begin{array}{l}\text { Saling mengenal } \\
\text { dan saling menyapa }\end{array}$ \\
\hline Agak tidak suka & Pengganggu & $\begin{array}{l}\text { Memilih untuk } \\
\text { menghindari kontak }\end{array}$ \\
\hline Sangat tidak suka & Tidak diinginkan & $\begin{array}{l}\text { Menghindari kontak } \\
\text { secara aktif }\end{array}$ \\
\hline
\end{tabular}


Menurut pandangan klasik, orang tertarik dengan orang lain karena terdapat penghargaan (rewards) dalam hubungan yang terjalin di antara mereka (Byrne \& Clore, 1970; Lott \& Lott, 1974, dalam Kassin, et. al., 2008). Penghargaan tersebut bisa secara langsung (seperti memberikan perhatian, dukungan, uang, status, informasi, dan lainnya) dan secara tidak langsung (seperti merasa lebih baik saat bersama orang yang cantik, cerdas, lucu, atau orang-orang yang kehadirannya bersama membuat kita baik). Perspektif lainnya yaitu psikologi evolusi menyatakan bahwa manusia di dunia ini menunjukkan ketertarikan dan menyeleksi pasangan yang disukai untuk mendukung proses konsepsi, kelahiran, dan bertahan hidup untuk keturunan mereka (Buss, 2004; Schaller et. al.,2006; Simpson \& Kenrick, 1997).

Secara umum beberapa faktor yang mendorong terjadinya ketertarikan antar individu, yaitu :

\section{Faktor internal (faktor dari dalam diri kita)}

\section{a. Harga diri}

Seseorang dengan harga diri yang tinggi cenderung memiliki keinginan untuk memberikan penghargaan sosial yang rendah, namun merasa percaya diri untuk mencarinya. Sedangkan seseorang dengan harga diri rendah, cenderung berkeinginan untuk memberikan penghargaan sosial yang tinggi, namun kurang percaya diri untuk memperoleh penghargaan tersebut (Brehm \& Kassin, 1996).

\section{b. Motivasi sosial}

Adanya motivasi sosial dalam diri individu yang berupa kebutuhan untuk berafiliasi (need for affiliation) dan kebutuhan untuk berhubungan intim (need for 
intimacy) mendorong individu untuk memuncukan ketertarikan dalam hubungan sosial.

c. Tekanan emosional (stress)

Jika seseorang berada dalam situasi yang mencemaskan atau menakutkan, cenderung menginginkan kehadiran orang lain. Kehadiran orang lain tersebut mendorong rasa suka pada individu tersebut (Dayakisni \& Hudaniah, 2003).

d. Perasaan atau mood positif (positive emotional arousal)

Kita cenderung tertarik atau menyukai orang lain yang kehadirannya bersamaan dengan munculnya perasaan positif, sekalipun perasaan positif ini tidak ada kaitannya dengan perilaku orang tersebut. Beberapa studi menunjukkan bahwa kita cenderung tertarik pada orang-orang yang kita temui saat sekeliling kita menyenangkan, sebaliknya ketertarikan kita terhadap orang lain berkurang saat sekeliling kita tidak menyenangkan seperti padat, bising, atau tercemar (Rotton, et. al., 1978; Glass \& Singer, 1972, dalam Dayakisni \& Hudaniah, 2003).

2. Faktor eksternal (faktor dari luar diri kita, berasal dari karakteristik orang lain)

a. Ketertarikan fisik

Penampilan fisik yang menarik memiliki keuntungan sosial, yaitu memunculkan ketertarikan pada orang lain dan lebih mudah mendapatkan bantuan (Hatfield \& Sprecher, 1986, dalam Suryanto et. al., 2012). Sebuah penelitian menunjukkan hasil bahwa sebagian besar orang percaya jika laki-laki dan perempuan yang 
menarik memiliki krakteristik positif, seperti menampilkan ketenangan, mudah bergaul, mandiri, dominan, gembira, seksi, mudah beradaptasi, sukses, lebih maskulin (untuk laki-laki) dan lebih feminin (untuk wanita) dibandingkan orang yang tidak menarik Baron \& Byrne, 2008).

\section{b. Kesamaan (similarity)}

Kita cenderung menyukai orang-orang yang memiliki kesamaan dengan kita, dalam hal sikap, nilai, minat, latar belakang, atribut fisik, dan kepribadian. Mengapa demikian ? Pertama, kita cenderung menyukai orang lain dimana mereka memiliki sikap yang sama dengan diri kita, agar seluruh unsur kognitif kita konsisten. Kedua, orang yang memiliki kesamaan dengan kita cenderung lebih mudah menyetujui pandangan kita dan mendukung keyakinan kita tentang kebenaran pandangan tersebut. Ketiga, orang lain yang memiliki kesamaan dengan kita, mendorong kita untuk bisa memperkirakan bahwa interaksi yang terjalin di masa yang akan datang akan positif dan memberikan keuntungan (Dayakisni \& Hudaniah, 2003).

\section{c. Kemampuan (ability)}

Kita cenderung menyukai orang lain yang secara sosisl memiliki kemampuan, kompeten, dan cerdas karena bisa memberikan keuntungan (reward) kepada kita. Tipe kemampuan atau kompetensi yang penting tergantung pada sifat dari hubungan kita dengan seseorang (Taylor et. al., 2009). Keuntungan tersebut di antaranya mampu membantu kita untuk menyelesaikan masalah, mampu memberikan nasehat, dan sebagainya. 


\section{Faktor situasional}

\section{a. Kedekatan (proximity)}

Orang cenderung menyukai orang lain yang tempat tinggalnya berdekatan. Hasil penelitian Festinger tentang pola pertemanan di perumahan mahasiswa yang sudah menikah menunjukkan bahwa mahasiswa akan berteman dengan orang yang dekat dengan tempat tinggalnya dibandingkan dengan yang jauh (Suryanto et. al., 2012). Terdapat beberapa alasan mengapa kedekatan menjadi faktor penentu ketertarikan interpersonal. Pertama, orang yang secara fisik dekat akan lebih mudah ditemui daripada orang yang jauh. Kedua, kedekatan seringkali berkaitan dengan kesamaan. Ketiga, kedekatan biasanya akan meningkatkan keakraban.

\section{b. Keakraban (familiarity)}

Orang yang tinggal dekat dengan kita akan menjadi akrab, sehingga bisa memperkuat daya Tarik interpersonal. Semakin sering kita bertemu dengan seseorang, akan meningkatkan rasa suka kita terhadap orang tersebut (Taylor et. al., 2009).

\section{c. Kesukaan timbal balik (reciprocal liking)}

Saat kita mengetahui bahwa orang lain menyukai kita, bisa mempengaruhi ketertarikan kita kepada orang tersebut. Secara umum kita menyukai orang yang juga menyukai kita, sebaliknya kita cenderung tidak menyukai orang lain yang tidak menyukai kita. 


\section{d. Saling melengkapi atau komplementer}

(complementary)

Tidak selamanya orang menyukai orang lain karena adanya kesamaan-kesamaan. Perbedaan di antara individu juga bisa memunculkan ketertarikan satu sama lain. Misalnya, individu yang memiliki kepribadian dominan, biasanya hubungan interpersonal yang terjalin dengan orang yang sama-sama dominan tidak lama. Individu yang dominan membutuhkan partner yang submisif yang akan saling membantu memenuhi kebutuhan-kebutuhan mereka. Perilaku yang saling melengkapi memungkinkan untuk kepribadian dominan-submisif (Strong et. al, 1988, dalam Dayakisni \& Hudaniah, 2003). Hasil penelitian Jones (Kruglanski \& Mayseless, 1987, dalam Pines, 1999, menunjukkan bahwa saat kita menyukai seseorang yang memiliki opini berbeda dengan kita, kita bisa belajar hal baru dan bernilai dari orang tersebut (Dayakisni \& Hudaniah, 2003).

\section{Hubungan Erat atau Akrab (Close Relationship)}

Orang-orang memiliki hubungan yang signifikan (significant relationship) dalam hidupnya, namun psikologi sosial fokus pada pertemanan, kekasih, dan pasangan suami isteri (Berscheid \& Regan, 2004; Fletcher, 2002; Hendrick \& Hendrick, 2000; Miller et.al.,2006, dalam Kassin et. al., 2008). Hubungan interpersonal antar individu terkadang berlangsung singkat, namun juga bisa berlangsung lama. 


\section{Komponen-komponen Dalam Hubungan Erat}

Kassin et. al. (2008) mengemukakan tiga komponen dalam hubungan yang intim (intimate relationship), sebagai berikut :

1. Merasakan kelekatan, afeksi (perasaan kasih sayang), dan cinta

2. Pemenuhan kebutuhan psikologis

3. Ketergantungan di antara partner, masing-masing saling mempengaruhi.

Menurut Kelley (dalam Sears et. al.,1985), hubungan erat memiliki ciri-ciri sebagai berikut :

1. Terdapat interdependensi yang kuat

2. Terdapat frekuensi interaksi yang kerap untuk waktu yang ralatif panjang

3. Melibatkan berbagai macam bentuk kegiatan dan peristiwa

4. Saling mempengaruhi

\section{Teori-teori Tentang Hubungan Erat}

Terdapat beberapa perspektif teori yang mencoba menjelaskan tentang hubungan erat, sebagai berikut :

\section{Teori Pertukaran Sosial (Social Exchange Theory)}

Teori ini merupakan sebuah model ekonomi tentang perilaku manusia dimana orang dimotivasi oleh sebuah keinginan untuk memaksimalkan keuntungan dan meminimalkan kerugian dalam hubungan sosial mereka seperti mereka berbisnis (Homans, 1961; Thibaut \& Kelley, 1959, dalam Kassin, et. al.,2008). Premis dasar dari teori ini sederhana, bahwa hubungan yang memberikan lebih banyak ganjaran (rewards) dan lebih sedikit biaya (costs) akan lebih memuaskan dan bisa bertahan lebih lama. 
Ganjaran tersebut bisa berupa cinta, persahabatan, hiburan saat stress. Sedangkan biaya yang bisa ditimbulkan meliputi usaha yang dibutuhkan untuk menjaga hubungan, konflik, kompromi, dan pengorbanan. Rasa suka kita kepada orang lain didasarkan pada penilaian keuntungan dan kerugian yang diberikan oleh seseorang pada kita.

Realitas yang terjadi dalam interaksi social, banyak ditemukan hubungan interpersonal yang tetap berlangsung meski tidak secara kaku mengikuti prinsip pertukaran tersebut. Margaret Clark et. al., (1986, dalam Dayakisni \& Hudaniah, 2003) mengemukakan dua tipe hubungan interpersonal. Pertama, hubungan pertukaran dimana partisipan mengharapkan timbal balik secara ketat dalam interaksi di antara mereka. Kedua, tipe hubungan komunal (communal relationship), hubungan interpersonal dimana partisipan mengharapkan respon timbal balik terhadap kebutuhan-kebutuhan satu sama lain, namunbiaya dan ganjaran tidak secara teliti dikontrol, seperti dalam hubungan persahabatan dan cinta.

\section{Teori Keadilan (Equity Theory)}

Teori ini merupakan turunan dari teori pertukaran sosial (Dayakisni \& Hudaniah, 2003). Teori keadilan menyediakan versi khusus tentang bagaimana pertukaran sosial dijalankan dalam interaksi interpersonal. Menurut teori ini, orang paling puas dengan sebuah hubungan ketika rasio antara keuntungan (benefit) yang mereka peroleh dan kontribusi yang mereka lakukan sama untuk kedua belah pihak. Jadi, keuntungan yang diperoleh seseorang sama dengan keuntungan yang diperoleh partnernya, dan kontribusi yang dikeluarkan sama dengan 
kontribusi partner (Adams, 1965; Messick \& Cook, 1983; Walster et. al., 1978, dalam Kassin et. al.,2008).

Keadilan (equity) berbeda dengan equality (persamaan atau kesetaraan). Berdasarkan teori keadilan (equity theory), keseimbangan lah yang diperhitungkan. Jika manfaat (benefits) yang diperoleh partner melebihi hubungan yang dilakukan namun juga melakukan kontribusi yang lebih besar, maka situasinya menjadi adil (equitable). Dalam hubungan yang tidak adil, akan mengganggu keseimbangan, yaitu saat seorang partner menerima lebih banyak manfaat (benefits) dibandingkan dengan kontribusi yang diberikan, sementara partner lainnya menerima manfaat yang lebih sedikit daripada yang selayaknya diterima. Hubungan interpersonal melibatkan proses tukar-menukar, dimana agar pertukaran tersebut bisa memunculkan keharmonisan dan perasaan senang atau puas, maka harus dilandasi dengan prinsip keadilan (Dayakisni \& Hudaniah, 2003).

\section{Teori Penguatan Afek (Reinforcement Affect Theory)}

Teori ini mengemukakan bahwa kita cenderung menyukai orang-orang yang memberikan penguatan atau pengukuh positif (rewards) kepada kita dan tidak menyukai orang-orang yang memberikan pengukuh negatif (punishment) kepada kita (Dayakisni \& Hudaniah, 2003).

\section{Tipe-tipe Hubungan Interpersonal}

Model pertukaran sosial menekankan pada kuantitas, yaitu lebih banyak (penghargaan, keadilan), maka lebih baik (kepuasan, ketahanan). Namun, apakah penghargaan (rewards) itu selalu diperlukan dalam hubungan interpersonal ? Bagaimana dengan perbedaan secara kualitatif 
dalam hubungan kita ? Apakah dengan lebih banyak penghargaan (rewards) mengubah kenalan biasa menjadi teman, dan teman menjadi kekasih, atau tipe-tipe hubungan ini berbeda dari satu orang dengan orang lain dalam cara-cara yang lain ? Berikut dipaparkan jenis-jenis hubungan interpersonal menurut Kassin et. al., (2008) :

1. Hubungan pertukaran (exchange relationships) dan hubungan komunal (communal relationships)

Menurut Margaret Clark dan koleganya, orang-orang beroperasi dengan model berbasis hadiah saat mereka berada dalam hubungan pertukaran (exchange relationships), yang dicirikan oleh adanya pembayaran dengan segera atas manfaat yang diberikan. Orang-orang menginginkan agar biaya (costs) yang telah dikeluarkan segara diberikan kompensasi, jadi saldonya nol. Namun tidak semua hubungan dibentuk seperti ini. Clark mengemukakan bahwa dalam hubungan komunal (communal relationships), partner merespon kebutuhan satu sama lain dan berbahagia dari waktu ke waktu, tanpa memperhatikan apakah orang-orang telah memberi atau menerima manfaat atau keuntungan.

2. Gaya kelekatan aman (secure attachment styles) dan gaya kelekatan tidak aman (insecure attachment styles)

Pendekatan ini disampaikan oleh Philip Shaver, Cindy Hasan, dan koleganya, dengan teorinya yang menyatakan bahwa bayi menampilkan gaya kelekatan yang berbeda pada orang tuanya, maka orang dewasa memerankan model kelekatan yang spesifik dalam hubungan romantis mereka (Cassidy \& Shaver, 1999; Rholes \& Simpson, 2004, dalam Kassin et. al., 2008). Bayi dengan kelekatan aman (secure attachment) menangis 
karena ditinggalkan ibunya dan berubah menjadi gembira saat ibunya datang kembali. Bayi dengan kelekatan tidak aman (insecure attachment) menunjukkan satu dari dua pola. Beberapa bayi menunjukkan kecemasan, mendekat dan menangis saat ibunya meninggalkan dia, namun menyambut ibunya dengan kemarahan atau apatis saat ibunya kembali. Bayi yang lain secara umum lebih memisahkan diri dan menghindar (avoidant), tidak bereaksi secara berlebihan pada kesempatan lain (Ainsworth et. al, 1978, dalam Kassin et. al., 2008).

Seberapa penting gaya kelekatan yang pertama (secure attachment) ? Apakah sebuah keamanan dan kepercayaan mengikat dalam tahun-tahun pertama kehidupan sebagai dasar untuk hubungan yang lebih erat di kemudian hari ? John Bowlby (1988), seorang psikiater berpendapat bahwa terdapat kaitan pada bayi dengan figur kelekatannya, dimana model ini membimbing hubungan mereka di kehidupan selanjutnya. Hasil peneltian menunjukkan bahwa bayi yang menunjukkan kelekatan aman, nantinya lebih positif dalam pandangan mereka terhadap orang lain (Cassidy et. al., 1996, dalam Kassin et. al., 2008). Maka, pada orang dewasa dengan gaya kelekatan aman (secure) memiliki hubungan keluarga yang positif, sedangkan orang dewasa yang gaya kelekatannya menghindar (avoidant) dan cemas (anxious) memiliki problem dengan satu atau kedua orang tuanya (Feeney \& Noller, 1990; Hazan \& Shaver, 1987, dalam Kassin et. al., 2008).

Sebagai tambahan, hasil peneltian lain menunjukkan bahwa orang dengan gaya kelekatan aman melaporkan memiliki kepuasan dalam hubungan dimana 
mereka bahagia, ramah, saling percaya, dan abadi. Secara kognitif, mereka adalah orang yang baik hati, dan mereka percaya pada cinta romantis. Sebaliknya, pada orang-orang yang gaya kelekatannya menghindar (avoidant), takut pada keintiman dan percaya bahwa cinta romantis itu pasti akan memudar, sedangkan orang-orang yang gaya kelekatannya cemas (anxious) melaporkan bahwa mereka memiliki kehidupan cinta dengan emosi yang memuncak dan menurun, preokupasi obsesif, kerelaan yang leih besar dibandingkan lainnya untuk membuat komitmen jangka panjang, memiliki daya tarik seksual yang ekstrem, dan cemburu.

Berdasarkan beberapa hasil peneltian yang telah dilakukan, terlihat bahwa orang dengan gaya kelekatan aman cenderung memiliki hubungan yang awet atau abadi. Namun prognosa untuk klasifikasi sebagai kelekatan tidak aman sulit untuk diprediksi, dengan hasil-hasil penelitian yang kurang konsisten. Yang penting adalah menyadari bahwa meskipun gaya kelekatan agak stabil dari waktu ke waktu, mungkin sebagai peninggalan pada masa bayi dan anak-anak, tidaklah menetap. Sebagai ilustrasi akan hal ini, hasil penelitian Lee Kirkpatrick dan Cindy Hazan (1994) menemukan bahwa sekitar 30 persen dari partisipan penelitiannya mereka memiliki gaya kelekatan yang berbeda dari yang semula pada empat tahun berikutnya. Agar tetap berada pada tema utama psikologi sosial bahwa manusia terbentuk oleh situasi dimana dia berada di dalamnya, penelitian menyarankan agar orang-orang secara kontinyu merevisi jenis kelekatan mereka sendiri dalam menanggapi pengalaman berhubungan dengan orang lain (Kassin et. al., 2008). 


\section{Cinta}

Fehr dan Russell (1991, dalam Kassin et. al., 2008) meminta pelajar untuk membuat daftar semua jenis cinta yang muncul dalam pikiran mereka. Mereka menghasilkan 216 item, seperti persahabatan, orang tua, persaudaraan, romantis, seksual, spiritual, obsesif, posesif, dan cinta remaja.

Robert Sternberg (1986) mempopulerkan Teori Segitiga Cinta (Triangular Theory of Love). Menurut Sternbergh, terdapat delapan tipe dasar cinta dan semua tipe tersebut dibentuk dari ada atau tidaknya ketiga komponen, yaitu komponen kedekatan atau keintiman (intimacy), komponen komitmen (commitment), dan komponen nafsu atau gairah (passion). Komponen pertama yaitu keintiman (intimacy), merupakan kedekatan yang dirasakan oleh dua orang dan terdapat kekuatan ikatan yang menahan mereka, misalnya cinta karib. Komponen kedua adalah nafsu atau gairah (passion), berdasarkan pada percintaan, ketertarikan fisik, dan seksualitas, seperti cinta membara. Sedangkan komponen ketiga adalah komitmen (commitment), yang merepresentasikan faktor kognitif seperti adanya keputusan bahwa kita mencintai dan ingin bersama-sama dengan orang lain, serta adanya komitmen untuk mempertahankan hubungan. Kombinasi dari ketiga komponen yang menghasilkan berbagai jenis cinta, bisa dilihat pada gambar di bawah ini (Gambar 8.1). 


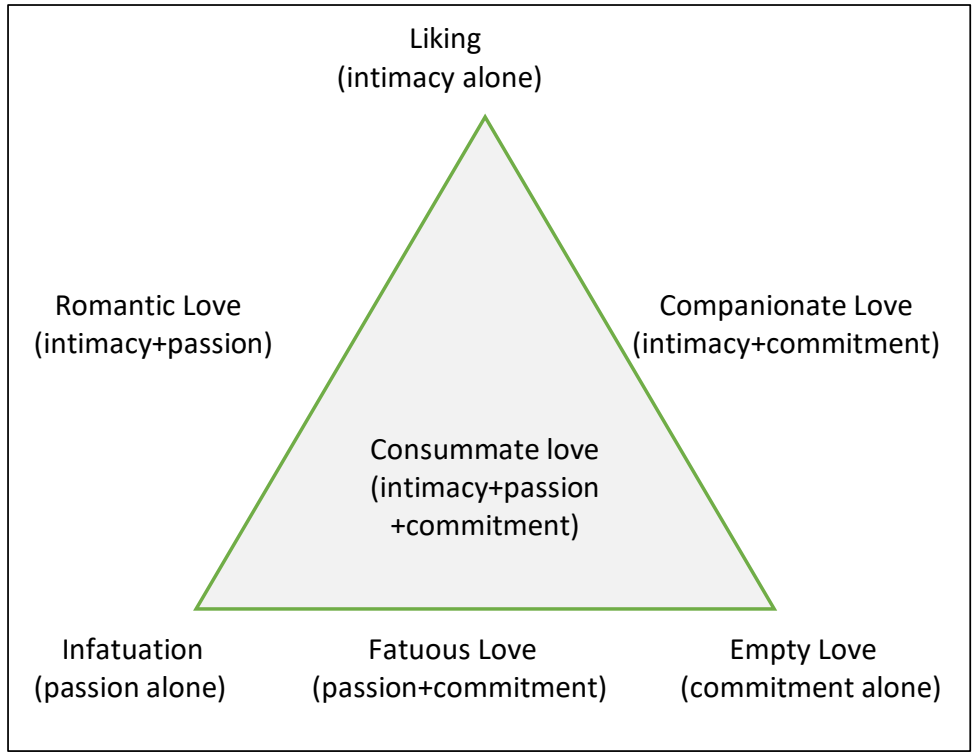

Gambar 8.1. Teori Segitiga Cinta (Triangular Theory of Love) Sternbergh

\section{Kegagalan Dalam Hubungan Erat}

Dalam hubungan yang erat, seringkali terjadi konflik yang tidak dapat dihindari, seperti dalam persahabatan, pernikahan, maupun dalam hubungan antara orang tua dan anak. Permasalahan yang secara umum seringkali terjadi dalam hubungan erat, sebagai berikut :

\section{a. Permasalahan komunikasi}

Salah satu sumber utama yang menjadi konflik dalam hubungan yang erat adalah kesulitan untuk membicarakan pertentangan yang terjadi di antara oraang-orang yang terlibat di dalam hubungan tersebut. Komunikasi menjadi salah satu penyebab utama, baik untuk pasangan heteroseksual maupun homoseksual (Kurdek, 1991; Sprecher, 1994, dalam Suryanto, et. al.,2012). 


\section{b. Permasalahan atribusi}

Bradbury dan Fincham (1990, dalam Dayakisni \& Hudaniah, 2003) menemukan bahwa pada pasangan yang menderita, memandang penyebab terjadinya permasalahan dalam pernikahan dikaitkan dengan atribut tanggung jawab tertentu untuk peristiwa negatif. Pasangan yang tidak bahagia lebih sering menyalahkan pasangannya, percaya bahwa pasangannya sengaja berbuat demikian, dan memandang pasangannya memiliki motif ingin menang sendiri. Sedangkan untuk peristiwa positif, dipandang hanya karena kebetulan.

Saat disadari bahwa hubungan yang erat mulai berkurang, muncul empat bentuk reaksi seperti yang disampaikan oleh Rushbold dan Zembrodt (1983, dalam Dayakisni \& Hudaniah, 2003). Pertama, reaksi membicarakan (voice), yaitu mendiskusikan masalah, mengkompromikan, mencari pertolongan dari ahli (seperti psikolog), mengusulkan pemecahan masalah, bertanya kepada pasangan apa yang mengganggu, mencoba untuk merubah diri sendiri atau partnernya. Reaksi kedua adalah kesetiaan (loyalty), yaitu menunggu dan berharap atau berdoa agar hubungan bisa membaik kembali, seiring dengan berjalannya waktu. Reaksi ketiga adalah menolak (neglect), merupakan reaksi yang mengabaikan pasangan, mengurangi intensitas untuk bersamasama, menolak berdiskusi tentang masalah, menghindari, memberikan perlakukan buruk kepada pasangan, mengkritik pasangan sekalipun tidak ada kaitannya dengan permasalahan utama, mengembangkan hubungan dengan yang lain. Reaksi yang terakhir adalah keluar (exit), yaitu pasangan secara resmi berpisah, keluar dari hubungan, mengancam akan mengakhiri 
hubungan, memutuskan untuk menganggap sebagai teman, bercerai.

Reaksi-reaksi di atas juga bisa dibedakan berdasarkan dua dimensi, yaitu :

a. Dimensi reaksi yang konstruktif dan destruktif Reaksi yang konstruktif meliputi :

1. Reaksi membicarakan (voice)

2. Reaksi kesetiaan (loyalty)

Reaksi yang destruktif meliputi :

1. Reaksi keluar (exit)

2. Reaksi menolak (neglect)

b. Dimensi reaksi yang aktif dan pasif

Reaksi aktif, meliputi :

1. Reaksi membicarakan (voice)

2. Reaksi keluar (exit)

Reaksi pasif, mencakup :

1. Reaksi kesetiaan (loyalty)

2. Reaksi menolak (neglect)

Berikut gambar reaksi orang-orang ketika menghadapi kemunduran dalam hubungan erat (Dayakisni \& Hudaniah, 2003). 


\begin{tabular}{|l|l|l|}
\hline \multicolumn{2}{|c|}{ Aktif } \\
\hline \multirow{2}{*}{$\begin{array}{c}\text { Keluar } \\
\text { (exit) }\end{array}$} & $\begin{array}{l}\text { Membicarakan } \\
\text { (voice) }\end{array}$ \\
\cline { 2 - 3 } & $\begin{array}{l}\text { Menolak } \\
\text { (neglect) }\end{array}$ & $\begin{array}{l}\text { Kesetiaan } \\
\text { (loyalty) }\end{array}$ \\
\hline \multicolumn{2}{c|}{ Pasif } \\
\hline
\end{tabular}

Gambar 8.2. Reaksi Menghadapi Permasalahan Dalam Hubungan Erat 


\section{BIODATA PENULIS}

Effy Wardati Maryam, S.Psi.,M.Si., lahir di Sidoarjo pada tanggal 16 Oktober 1976. Sejak tahun 2005 hingga saat ini aktif sebagai Dosen PNS dpk di Fakultas Psikologi Universitas Muhammadiyah Sidoarjo (UMSIDA). Pendidikan S1 Psikologi ditempuh di Universitas Muhammadiyah Malang (UMM), dilanjutkan dengan menempuh pendidikan S2 Magister Sains Psikologi dengan peminatan Psikologi Komunitas dan Pembangunan di Universitas Airlangga Surabaya. Bidang keahlian yang ditekuni adalah Psikologi Sosial. Fokus kajian dan penelitian yang dikembangkan mengenai pemberdayaan masyarakat, modal sosial, sense of community, dan kemiskinan. 


\section{DAFTAR PUSTAKA}

Baron, R.A., dan Byrne, D., 2003. Psikologi Sosial Jilid 1. Edisi Kesepuluh. Erlangga, Jakarta.

Baron, R.A., dan Byrne, D., 1994. Social Psychology : Understanding Human Interaction. Allyn \& Bacon, Inc, Boston.

Brehm, S.S., dan Kassin, S.M., 1996. Social Psychology. Third Edition. Prentice-Hall, London.

Brigham, J.C., 1991. Social Psychology. Harper Collins Publishers, New York.

Dayakisni, T., dan Hudaniah, 2003. Psikologi Sosial. Edisi Revisi. UMM Press, Malang.

Delamater, J. 2006. Handbook of Social Psychology. Springer, New York.

Delamater, John D. dan Myers, Daniel J. 2011. Social Psychology Seventh Edition. Wadsworth Cengage Learning, USA

Kassin, S., Fein, S., dan Markus, H.R., 2008. Social Psychology. $7^{\text {th }}$ Edition. Houghton Mifflin Company, New York.

Kenrick, D.T., Neuberg, S.L., dan Cialdini, R.B. 2002. Social Psychology : Unravelling The Mystery. Second Edition. Allyn and Bacon Inc.,Boston. 
Manis, M. Nelson, T.E., dan Shelder, J., 1988. Stereotypes and Social Judgement : Extremity, Assimilation, and Contrast. Journal of Personality and Social Psychology, 55, 28-36.

Myers, D.G., 2002. Social Psychology. Seventh Edition. McGraw-Hill Inc, New York.

Sarwono, Sarlito, W. 2002. Psikologi Sosial, Individu dan Teori-teori Psikologi Sosial. Balai Pustaka, Jakarta.

Sarwono, Sarlito, W., dan Meinarno, Eko A., 2009. Psikologi Sosial. Salemba Humanika, Jakarta.

Sears, D.O., Freedman, J.L., dan Peplau, L.A., 1985. Social Psychology, Fifth Edition. Prentice-Hall, Inc., Toronto

Suryanto, Putra, M.G.B.A., Herdiana, I., dan Alfian, I.N., 2012. Pengantar Psikologi Sosial. Airlangga University Press, Surabaya.

Taylor, S.E., Peplau, L.A., dan Sears, D.O., 2009. Psikologi Sosial. Edisi Kedua Belas. Kencana, Jakarta. 
131 
132 